\title{
DEVELOPMENT OF AN ASSESSMENT METHODOLOGY FOR GEOPRESSURED ZONES OF THE UPPER GULF COAST BASED ON A STUDY OF ABNORMALLY PRESSURED GAS FIELDS IN SOUTH TEXAS
}

Final Report

R.K. Swanson, P. Oetking, J.S. Osoba, R.C. Hagens

Southwest Research Institute

$$
8500 \text { Culebra Road }
$$

San Antonio, Texas 78284

Prepared for

THE U. S. ENERGY RESEARCH AND DEVELOPMENT ADMINISTRATION UNDER CONTRACT NO. E(11-1)-2687

August 1976

Approved:

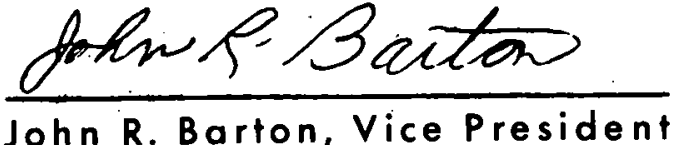

Instrumentation Research Division 


\section{DISCLAIMER}

This report was prepared as an account of work sponsored by an agency of the United States Government. Neither the United States Government nor any agency Thereof, nor any of their employees, makes any warranty, express or implied, or assumes any legal liability or responsibility for the accuracy, completeness, or usefulness of any information, apparatus, product, or process disclosed, or represents that its use would not infringe privately owned rights. Reference herein to any specific commercial product, process, or service by trade name, trademark, manufacturer, or otherwise does not necessarily constitute or imply its endorsement, recommendation, or favoring by the United States Government or any agency thereof. The views and opinions of authors expressed herein do not necessarily state or reflect those of the United States Government or any agency thereof. 


\section{DISCLAIMER}

Portions of this document may be illegible in electronic image products. Images are produced from the best available original document. 


\section{ABSTRACT}

Detailed study of the producing gas fields in south Texas has identified a total of 47 abnormally pressured fields in a six-county area including Hidalgo, Brooks, Cameron, Willacy, Kenedy, and Live Oak Counties. An assessment methodology for assessing the potential of the deep geopressured zone in south Texas as an energy resource was developed, based on investigation of the reservoir parameters of these fields. This methodology is transferrable to broad areas of the Gulf Coast.

The depth of the geopressured zone in the study area ranges from $7000 \mathrm{ft}$ in western Hidalgo to $12,000 \mathrm{ft}$ in central Cameron County. Except for Live Oak County, which represents Wilcox production, geopressured sediments in south Texas are mainly in the Vicksburg formation. Over much of the area, the top of the geopressured zone approximately coincides with the top of the Vicksburg.

Temperature data from within the fields, corrected to undisturbed reservoir values, yields a $300^{\circ} \mathrm{F}$-isogeothermal surface at depths from $10,500 \mathrm{ft}$ to $17,000 \mathrm{ft}$ over the study area. Although control is limited, a $375^{\circ} \mathrm{F}$-surface was found to occur at depths from $14,000 \mathrm{ft}$ in southwestern Live Oak County to more than $20,000 \mathrm{ft}$ on the Coast in eastern Kenedy County.

The question of fluid deliverability was found to be paramount in determining the potential of the geopressure-geothermal resource as a practical source of energy. The critical parameter is the effective reservoir permeability throughout the study region. Permeability values range from less than $0.03 \mathrm{md}$ to more than $8 \mathrm{md}$, with average values over all the fields near $1 \mathrm{md}$. Permeability was found to be a strong function of depth, and permeability profiles of fields at opposite geographic extremes in the study area exhibit a uniform reduction in permeability with depth which amounts to approximately 1 order of magnitude for each $2000 \mathrm{ft}$ of depth in the range from 6,000 to $14,000 \mathrm{ft}$.

Individual fields were assessed for their potential to produce large quantities of geothermal fluid based on reservoir study and detailed geological investigation. Five locations within the study region have been selected as potential candidates for further evaluation and possible eventual testing.

Based on investigation of permeability and temperature, the upper limit of fluid temperature likely to be produced in the lower south Texas study region is $300^{\circ} \mathrm{F}$. In Live Oak County, the possibility of producing fluid at higher temperatures is somewhat improved, with a reasonable possibility of producing fluid at $350^{\circ}$ to $375^{\circ} \mathrm{F}$. 
LIST OF ILLUSTRATIONS . . . . . . . . . . . . . . . . . . . . . . . . . . . . . . vii

I. INTRODUCTION . . . . . . . . . . . . . . . . . . . . . . . . . . 1

II. RESEARCH METHODOLOGY . . . . . . . . . . . . . . . . . . . . . . . . . . . 3

A. Study Region . . . . . . . . . . . . . . . . . . . . . . . . . . . 3

B. Methodology . . . . . . . . . . . . . . . . . . 3

1. Location of Producing Fields . . . . . . . . . . . . . . . . . . . 3

2. Identification of Geopressured Production . . . . . . . . . . . . . . . . 4

3. Well Logs and Completion Data . . . . . . . . . . . . . . . . . . 4

4. Geologic Investigation . . . . . . . . . . . . . . . . . . . . . 5

5. Temperature Data . . . . . . . . . . . . . . . . . . . . . . . 5

6. Reservoir Study . . . . . . . . . . . . . . . . . . . . 6

7. Well Test Results . . . . . . . . . . . . . . . . . . . . . . . . 6

8. Presentation of Results . . . . . . . . . . . . . . . . . . . . . . . . . . 7

III. STUDY RESULTS . . . . . . . . . . . . . . . . . . . . . . . . . . . . . . . . . . 8

A. Geologic Setting . . . . . . . . . . . . . . . . . . . . . . . . . . 8

B. Occurrence of Geopressure . . . . . . . . . . . . . . . . . . . . . . . 8

C. Temperature Characteristics . . . . . . . . . . . . . . . . . . . . . 10

1. Geologic Temperature Horizons . . . . . . . . . . . . . . . . . . 17

2. Detailed Field Temperature Studies . . . . . . . . . . . . . . . . . 17

D. Reservoir Characteristics . . . . . . . . . . . . . . . . . . . . . . . 20

1. Fluid Deliverability . . . . . . . . . . . . . . . . . . . . . . . 20

2. Reservoir Parameters .. . . . . . . . . . . . . . . . . . . . 21

E. Permeability of South Texas Gas Reservoirs . . . . . . . . . . . . . . . 23

1. Western Hidalgo-Central Brooks County. . . . . . . . . . . . . . . . 24

2. Hidalgo County-Tabasco Fault Area . . . . . . . . . . . . . . . . 25

3. Hidalgo County-Lower McAllen Fault . . . . . . . . . . . . . . . . . . . . . . 25

4. Hidalgo County, Southwestern Kenedy County-Upper McAllen Fault Zone : . 25

5. Eastern Brooks County, Northern Kenedy County . . . . . . . . . . . 25

6. Cameron County, Willacy County . . . . . . . . . . . . . . . . . 25

7. Live Oak County. . . . . . . . . . . . . . . . . . . . . . . . 27

F. Investigation of Depth Effect on Permeability . . . . . . . . . . . . . . . . . 27

G. Significance of Permeability to Long-Term Water Well Performance . . . . . . . . 27

H. Water Salinity . . . . . . . . . . . . . . . . . . . . . . . . . . . 30 


\section{TABLE OF CONTENTS (Cont'd)}

I. Reports of Well Tests . . . . . . . . . . . . . . . . . . . . . . . . 30

1. Donna Area, Hidalgo County . . . . . . . . . . . . . . . . . . . 32

2. Santa Maria Area . . . . . . . . . . . . . . . . . . . . . . . . 32

3. Mercedes Area . . . . . . . . . . . . . . . . . . . . . . . . . 32

4. Edinburg Area . . . . . . . . . . . . . . . . . . . . . . . . . 32

5. Sou thern Brooks County, Encinitas Area . . . . . . . . . . . . . . 35

6. Effect of Fracture Treatment . . . . . . . . . . . . . . . . . . . 37

7. Live Oak County, Tom Lyne Area . . . . . . . . . . . . . . . . . 37

IV. GEOLOGY AND ASSESSMENT OF PRODUCING AREAS . . . . . . . . . . . . 39

A. Brooks County-The Frio-Vicksburg Flexure . . . . . . . . . . . . . . . 39

1. South Ann-Mag Field (No. 36 on Figure 2) . . . . . . . . . . . . . . 40

2. Viboras Field (No. 33 on Figure 2) . . . . . . . . . . . . . . . . . . . 40

3. Kelsey-Encinitas Area (Nos. 28 and 29 on Figure 2) . . . . . . . . . . . . . : 41

4. La Encantada Field . . . . . . . . . . . . . . . . . . . . . . . 41

5. Scott and Hopper Field (Map No. 31) . . . . . . . . . . . . . . . . 41

6. Skipper-Cage Ranch-Alta Mesa Area (Map Nos. 32, 34, 35) . . . . . . . . . 45

7. Summary of Brooks County Investigation . . . . . . . . . . $\vdots . . .45$

B. Kenedy County . . . . . . . . . . . . . . . . . . . . . . . . . . 45

1. Candelaria Field . . . . . . . . . . . . . . . . . . . . . . . . 45

2. Rita Southeast . . . . . . . . . . . . . . . .. . . . . . . . . 47

3. El Paistle, Sarita East, and Baffin Bay . . . . . . . . . . . . . . . . 47

4. Sorillo . . . . . . . . . . . . . . . . . . . . . . . . . 51

5. Tordilla-Stillman Area . . . . . . . . . . . . . . . . . . . . . . . 51

6. Summary of Kenedy County Investigation . . . . . . . . . . . . . . 51

C. Hidalgo County . . . . . . . . . . . . . . . . . . . . . . . . . . 51

1. Western Hidalgo County . . . . . . . . . . . . . . . . . . . . . 52

2. Tabasco Fault Area . . . . . . . . . . . . . . . . . . . . . . . . 56

3. The McAllen Fault-Lower Hidalgo County . : . . . . . . . . . . . . . . . 59

4. Upper McAllen Fault . . . . . . . . . . . . . . . . . . . . . . . . 62

D. Live Oak County . . : . . . . . . . . . . . . . . . . . . . . . . 64

1. Individual Fields in Live Oak County . . . . . . . . . . . . . . . . 65

2. Nonelectric Uses of Geothermal Fluid . . . . . . . . . . . . . . . 69

E. Cameron County $\because \cdots$

F. Willacy County . . . . . . . . . . ............... . . . 69 
V. CONCLUSIONS AND RECOMMENDATIONS . . . . . . . . . . . . . . . . . . . 70

A. Summary of Results . . . . . . . . . . . . . . . . . . . . . . . . 70

1. Depth and Occurrence of Geopressure . . . . . . . . . . . . . . . . . 70

2. Temperature Regime . . . . . . . . . . . . . . . . . . . . . 70

3. Reservoir Parameters . . . . . . . . . . . . . . . . . . . . 70

B. Conclusions . . . . . . . . . . . . . . . . . . . . . . . 71

C. Recommendations . . . . . . . . . . . . . . . . . . . . . . . . . . 71

BIBLIOGRAPHY .. . . . . . . . . . . . . . . . . . . . . . 74

APPENDIX A-Fields with Production Depths Deeper than 7000 Feet by County

South Texas Study Area . . . . . . . . . . . . . . . . . . . . . . . . . A-1

APPENDIX B-Core Record of Shell No. 13 McAllen, McAllen Ranch Field,

Hidalgo County, Texas (Courtesy of Shell Oil Company) . . . . . . . . . . . . . . . B-1

APPENDIX C-Calculation of Pressure and Flow From a Single Well in the

Center of a Circular Reservoir . . . . . . . . . . . . . . . . . . . . . . . . . . C-1 


\section{LIST OF ILLUSTRATIIONS}

Figure

Page

1 South Texas Study Region, Showing Relative Location (Inset) . . . . . . . . 1

2 Geopressured Gas Fields Identified in Study Region . . . . . . . . . . . . 5

3 Six-County Study Region Located in Relation to Major Geologic

Features of South Texas . . . . . . . . . . . . . . . . . . . . . . . . 9

4 Depth of Top of Geopressured Zone in Representative Gas Fields

in South Texas. . . . . . . . . . . . . . . . . . . . . . . . . . . . . 10

5 Structure Map on Top of " 8500 " Sand (Approx. Top Geopressure)

in McAllen-Pharr Field, Hidalgo County , Texas . . . . . . . . . . . . . . 11

6 Structure Map on Top of "Hansen" Sand, McAllen-Pharr Field, Approx. $800 \mathrm{ft}$

Below Datum on. Figure 5, Showing Increased Faulting with Depth . . . . . . 11

7 Cross Section, McAllen-Pharr Field, Hidalgo County, Texas, Section AA on

Figure 6 (After Collins, 1967) .. . . . . . . . . . . . . . . . . . . . . 12

8 Fields with Depth of $300^{\circ} \mathrm{F}\left(150^{\circ} \mathrm{C}\right)$ Geotherm Less Than 11,000 Feet . . . . . 14

9 Effect of Wellhead Temperature on Hot Water Consumption for Power

Production (Holt, 1974) . . . . . . . . . . . . . . . . . . . . . . . 14

10 Temperature vs. Depth for Representative Fields Across South Texas

Producing Counties :. . . . . . . . . . . . . . . . . . . . . . . . . 15

11 Approximate Depth of $375^{\circ} \mathrm{F}\left(190^{\circ} \mathrm{C}\right)$ Geothermal Surface . . . . . . . . . 16

12 McAllen-Pharr-Edinburg Area . . . . . . . . . . . . . . . . . . . . . 18

13 Formation Temp (Linear Scale) Plotted with Shale Resistivity (Log Scale)

Both vs. Depth in Deep Well in McAllen Ranch Field, Hidalgo County, Texas . . 19

14 Reduction in Permeability as a Function of Confining Pressure $\mathrm{K}_{\text {AIR }}=367 \mathrm{md}$. . 23

15 Representative Permeability, md Vicksburg Fault Area, Hidalgo County . . . . 24

16 Representative Permeability, md Vicksburg Fault Area, Brooks County . . . . . 25

17 Representative Permeability, md Tabasco Fault Area, Hidalgo County . . . . . 25

18 Representative Permeability, md Lower McAllen Fault Area, Hidalgo County . . 26

19 Representative Permeability, md Upper McAllen Fault,.

Hidalgo-Kenedy Counties . . . . . . . . . . . . . . . . . . . . . . 26 


\section{LIST OF ILLUSTRATIONS (Cont'd)}

Figure

Page

20 Representative Permeability, md Kenedy-Brooks Counties . . . . . . . . . . . . 26

21 Representative Permeability, md Cameron-Willacy Counties . . . . . . . . . . . 26

22 Representative Permeability, md Live Oak County . . . . . . . . . . . . . 27

23 Effective Permeability vs. Depth for a Large Number of Gas Wells in

Hidalgo, Brooks, Cameron and Kenedy Counties in South Texas . . . . . . . 28

24 Variation of Effective Permeability with Depth, McAllen-Pharr Area . . . . . . 29

25 Variation of Permeability with Depth, Ann-Mag Field, Northern Brooks Co. . . . 29

26 Flowing Time, Days, for Which a Well Can Maintain a Flowing Rate of 100,000

BBL Water Per Day, vs. Reservoir Permeability . . . . . . . . . . . . . . 30

27 Connate Water Salinity, ppm Cl, Representative Geopressured Producing

Reservoirs in South Texas . . . . . . . . . . . . . . . . . . . . 31

28 South Hidalgo County Test Well . . . . . . . . . . . . . . . . . . . . . 33

29 J.M. Huber No. 1 A Miller, Weslaco Area Hidalgo County, Texas . . . . . . . . . . 34

30 South Brooks County Well in Which Deep Vicksburg Production Tests

Were Reported . . . . . . . . . . . . . . . . . . . . . . . . . . . 36

31 South Brooks County Vicksburg Well in Which Frac Treatment is Shown to Increase Effective Permeability About Two-Fold . . . . . . . . . . . . . 38

32 Structure Map on Datum Near Base Frio-Ann-Mag Field, Brooks

County, Texas . . . . . . . . . . . . . . . . . . . . . . . . . . . 40

33 Structure Map on Lower Frio Massive Sand-Viboras Field,

Brooks County, Texás . . . . . . . . . . . . . . . . . . . . . . . . 42

34____Potential.Geothermal Sands in-Frio-Vicksburg and Vicksburg Sands,

S.E. Viboras Field, Brooks County, Texas . . . . . . . . . . . . . . . . 43

35 Structure Map on Sand Horizon Near Top Vicksburg-Encinitas-Kelsey Area, Brooks County, Texas . . . . . . . . . . . . . . . . . . . . . . 44

36 Deep Vicksburg Sand Development Typical of Central Brooks County, Texas ‘ . 46

37 Structure Map on Top $8500 \mathrm{ft}$ Frio Sand-Candelaria Field, Kenedy

County, Texas . . . . . . . . . . . . . . . . . . . . . . . . . . 


\section{LIST OF ILLUSTRATIONS (Cont'd)}

Figure

Page

38 Structure Map on Possible Top Vicksburg-Candelaria Field,

Kenedy County, Texas

39 Log Section of Geopressured Sediments Penetrated in Sarita Field,

Kenedy County, Texas

40 Type-Log, Jeffress Field, Hidalgo Co., Texas Showing Two Large Vickssburg

Blanket Sands, "S" and "T"

41 Structure Vicksburg "S" Sand Jeffress Field, Hidalgo County, Texas .

42 Structure Vicksburg "T" Sand, Jeffress Field, Hidalgo County, Texas

43 Log of Geopressured Sediments, McAllen Ranch Field,

Hidalgo County, Texas . . . . . . . . . . . . . . . . . . . . . . . 56

44 Structure Top Vicksburg "L" Sand, McAllen Ranch Field, Hidalgo County, Texas. 57

45 Structure Top Vicksburg "S" Sand, McAllen Ranch Field, Hidalgo County, Texas . 58

46 Well Log of Deep, Geopressured Sands in McAllen Field,

Hidalgo County, Texas

Structure Top Marks Sand-McAllen-Pharr-Edinburg Area .

48 Type Log, N. Weslaco Field Showing Massive Deep Frio-Vicksburg Fresh Water

Sands to 14,000 ft (North Pump No. 2 Harris)

49 Area Structure Map on Top Wilcox "A" Sand Horizon for Fields in South

Central Live Oak County, Texas . . . . . . . . . . . . . . . . . . . . . . 66

50 Cross Section Katz-Slick Structure, Live Oak County, Texas _. . . . . . . . . 67

51 Deep Wilcox Development Off-Structure, (Well No. 8) to Northeast

Katz-Slick Field, Live Oak County, Texas . . . . . . . . . . . . . . . . . . 68

Areas Recommended for Further Evaluation and Testing 


\section{INTRODUCTION}

The northern coastal region of the Gulf of Mexico basin, from Mexico to Mississippi, is underlain by deep zones of abnormal pressures and elevated temperatures. Knowledge of these temperatures, pressures, and sediments is primarily the result of information gained during the drilling of tens of

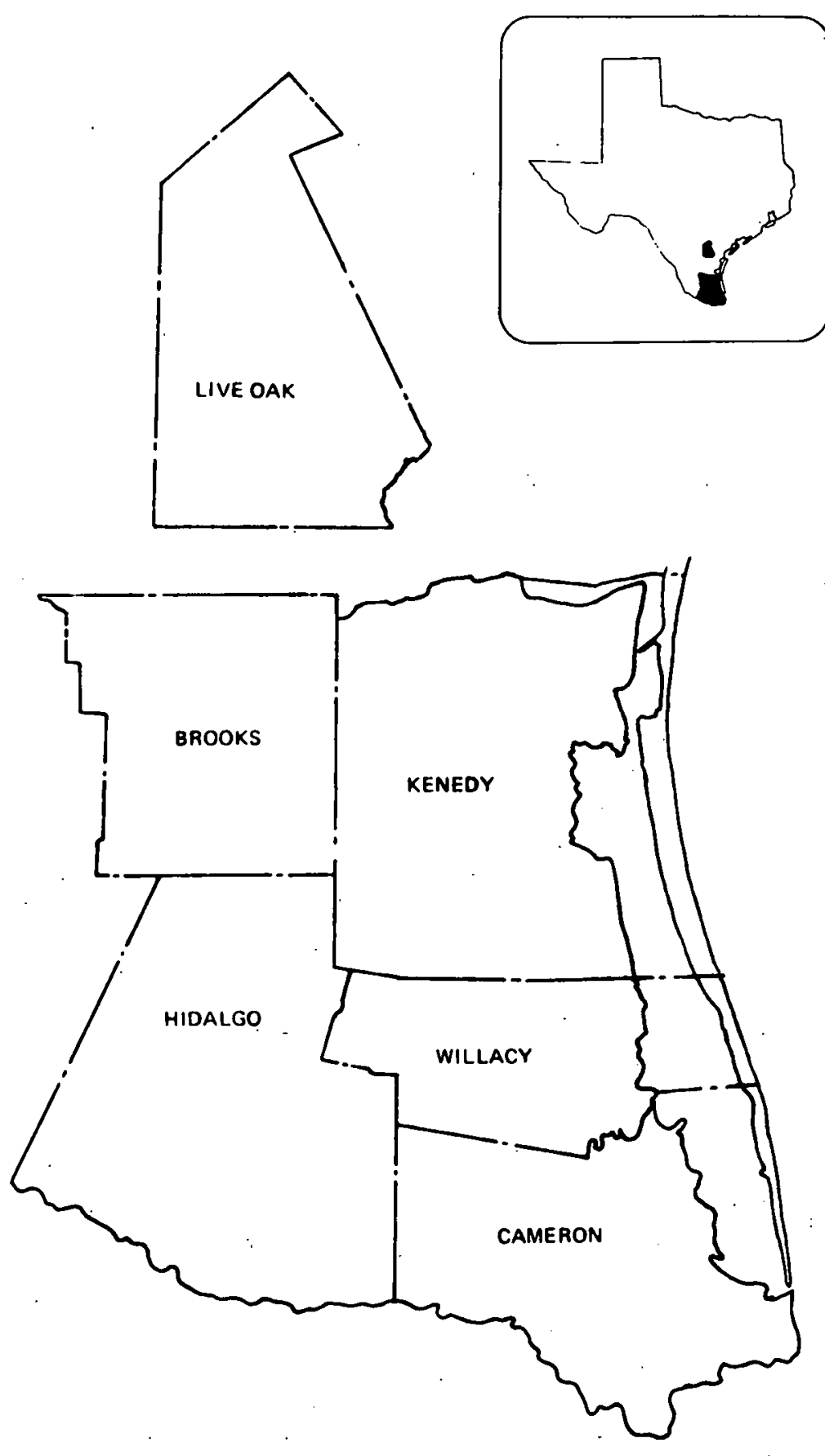

FIGURE 1. SOUTH TEXAS STUDY REGION, SHOWING RLLATIVE LOC.ATION (INSI:T) thousands of petroleum exploration wells over the last 50 years. The abnormal pressures are believed to be the result of arrested compaction of shale with increasing depth of burial, as a result of impaired subsurface drainage. The occurrence of countless major and minor growth faults, generally parallel to the Coast, undoubtedly dominates this process. The resulting abnormal pressure is known as "geopressure." The increased temperature gradients are thought to be the result of the insulating properties of the undercompacted shale. These beds impair the normal flow of heat from below the earth's crust, thus producing subsurface temperatures higher than considered normal.

This report documents a study of one of these prominent geopressured regions on the Gulf Coast. This study is based upon a detailed investigation of production records and other data from a large number of producing gas fields in the area. The region, noted for its history of abnormal pressures, is located in extreme south Texas. It includes the counties of Hidalgo, Brooks, Cameron, Willacy, and Kenedy, which make up the south Texas coastal region, and Live Oak County in south central Texas. Live Oak County was added to the investigation because it represents a region of known high pressure and temperature on a separate geologic trend. The study region is shown on the map in Figure 1. 
Instrumental to the study was the identification of gas fields with a history of production from geopressured formations. Because of the relatively large number of these fields, their systematic study was expected to illuminate significant outstanding questions concerning the exploitation of the deep. geopressured zones, which show promise as a source of geothermal energy. The high-pressure hot water they contain represents hydraulic energy and thermal energy, and, perhaps of overriding importance, the water may also be saturated with methane. If wells can be completed in these zones capable of producing large quantities of hot water, these sandstone reservoirs could comprise a useful energy resource.

Proper assessment of the potential of this resource is at an early stage of development. Petroleum exploration technology is useful, but not complete for the purpose. In order for practical production of energy from this resource to become a reality, several conditions must be coincident. First, large aquifers of considerable thickness at temperatures higher than $150^{\circ} \mathrm{C}\left(300^{\circ} \mathrm{F}\right)$ must be located. Second, these aquifers must be continuous over areas measured in terms of many square kilometers; third, the reservoir rock must have sufficient porosity to con tain large quantities of water; and fourth, effective permeability must permit the delivery of tens of thousands of barrels of water per day per well. A reasonable starting point for an assessment of the occurrence of these conditions is a study of the production history of producing petroleum reservoirs in the zones of interest. 


\section{RESEARCH METHODOLOGY}

\section{A. Study Region}

The results presented in this report apply to a region in extreme south Texas encompassing Cameron, Willacy, Hidalgo, Brooks, and Kenedy Counties, and the geographically separate southcentral Texas County of Live Oak. Geopressure at moderate depth is known to exist throughout the area, and the temperature gradient is among the highest in the Gulf Coast basin. Oil and gas have been produced prolifically over much of the area since the 1930's, and the geothermal potential has been under geologic and hydrologic investigation for a number of years by the USGS and others. However, no comprehensive investigation of reservoir parameters has previously been reported.

The entire region of the study is a sparsely populated, arid geographic area devoted almost exclusively to agriculture and ranching. The three-county segment made up of Hidalgo, Willacy, and Cameron Counties is generally referred to as the "Lower Rio Grande Valley" of Texas. The three largest cities, McAllen, Harlingen, and Brownsville, are all located near the Mexican border in a narrow, irrigated agricultural belt. In large part, the region has only token industrial activity, restricted primarily to canning, oil and gas production, and, in Live Oak County, some uranium mining. The terrain throughout the area is flat and relatively featureless, and has been the site of important natural gas production since the period immediately preceding World War II. Nearly 300 producing fields are listed in Texas Railroad Commission records for the six-county area. Of these fields, 47 have been identified as producing from abnormally pressured zones.

\section{B. Methodology}

The purpose of this program is to establish a methodology for assessment of the deep geopressured zone on the Gulf Coast, based on a detailed examination of south Texas gas fields which have produced substantial quantities of fluids from these zones. Of principal importance to this effort was the identification of the number and location of geopressured producing fields in the study region. Such an investigation had not previously been reported.

\section{Location of Producing Fields}

The first significant task in the project was the location of all producing fields in the region. This task was accomplished by obtaining the Texas Railroad Commission field listings for Southwest Texas, Districts 2 and 4. These listings were placed in a computer file, and the file sorted by county. After the initial county listings were obtained, all fields with producing depths below $7000 \mathrm{ft}$ were identified. This process of preliminary selection was based upon a thorough review of the literature, and knowledge of geopressure as described by notable workers in the field (e.g., Dickinson, 1953; Hottman and Johnson, 1965; Hottman, 1966; Jones, 1969; Wallace, 1970; Bebout, et al., 1975 and others), and by detailed USGS study (to be published) of occurrence of geopressure within the lower part of the study region. No significant occurrence of geopressure has been reported in south Texas at depths less than $7000 \mathrm{ft}$, and the known geothermal gradients are such as to preclude a useful geothermal source at lesser depths. This initial tabulation of fields deeper than $7000 \mathrm{ft}$ for the six counties in the study appears in Appendix A. A breakdown listing fields with production at depths below $10,000 \mathrm{ft}$ also appears as a matter of interest. 


\section{Identification of Geopressured Production}

In order to identify the geopressured production, all producing wells in each of the listed fields were identified, from two sources.

\section{a. Geologic Mapping Service}

Early in the project, the mapping service of Geomap of the Gulf Coast, Inc. was obtained. This service provides continually updated regional maps marked with well location, operator identification, and total depth. Regional geology is also mapped and periodically updated. Although the geologic coverage of the deep horizons of principal interest to the geopressure study is not complete, the general geology is extremely useful.

\section{b. Ownership Maps}

Somewhat more complete well identification, particularly from the older fields, was obtained from ownership maps available from various mapping services. These maps show land ownership, leasing arrangements, and well locations. Wells were identified in each of the producing fields on the basis of production and total depth. The deepest wells drilled in each field were identified.

\section{Well Logs and Completion Data}

Well logs were obtained from wells from each of the listed fields. Access to several south Texas log libraries was obtained through the services of one of the project consultants, Mr. R. C. Hagens of Corpus Christi. Completion cards on these wells were obtained from a scouting service.

From the logs and completion cards, the average depth of the geopressured zone in each field was established. If the top of geiopressure was deeper than the deepest production identified in the field, the field was eliminated from further consideration (some deep-well information was used in the study of temperature and geopressure, however).

If the field had produced from one or more horizons in the geopressured zone, all the available well logs from the field were obtained.

This field identification process was tedious and consumed considerable time. Unfortunately, no simple method was ever developed for accomplishing this task. Identification of the geopressured zone in many of the fields was sufficiently difficult to require all information available. A method originally described by Hottman and Johnson (1965) is based on determination of the resistivity of shale from the amplified short normal on the electric log. It is generally found that shale resistivity increases with depth in the zones of major compaction (generally below 6000 to $8000 \mathrm{ft}$ ), when pressures are normal. Reversal of this trend, i.e., reduction in shale resistivity with depth, may signal abnormal pressure, resulting in arrested shale compaction. This "shale resistivity ratio" method was found to be useful in most cases, but required confirmation from casing depth and mud weight. Intermediate casing is usually set near the depth of expected high pressures, and the mud weight record generally assists in isolating the zone of drilling problems caused by abnormal pressure.

In many of the fields, deep control was seriously limited, with only one abnormally pressured well in an otherwise shallow, normally pressured field. Many geopressured fields are onewell producers. 
The final result of the sorting process yielded a total of 47 separate geopressured gas fields in the study region. These gas fields are shown on the map in Figure 2 and identified in Table $I$.
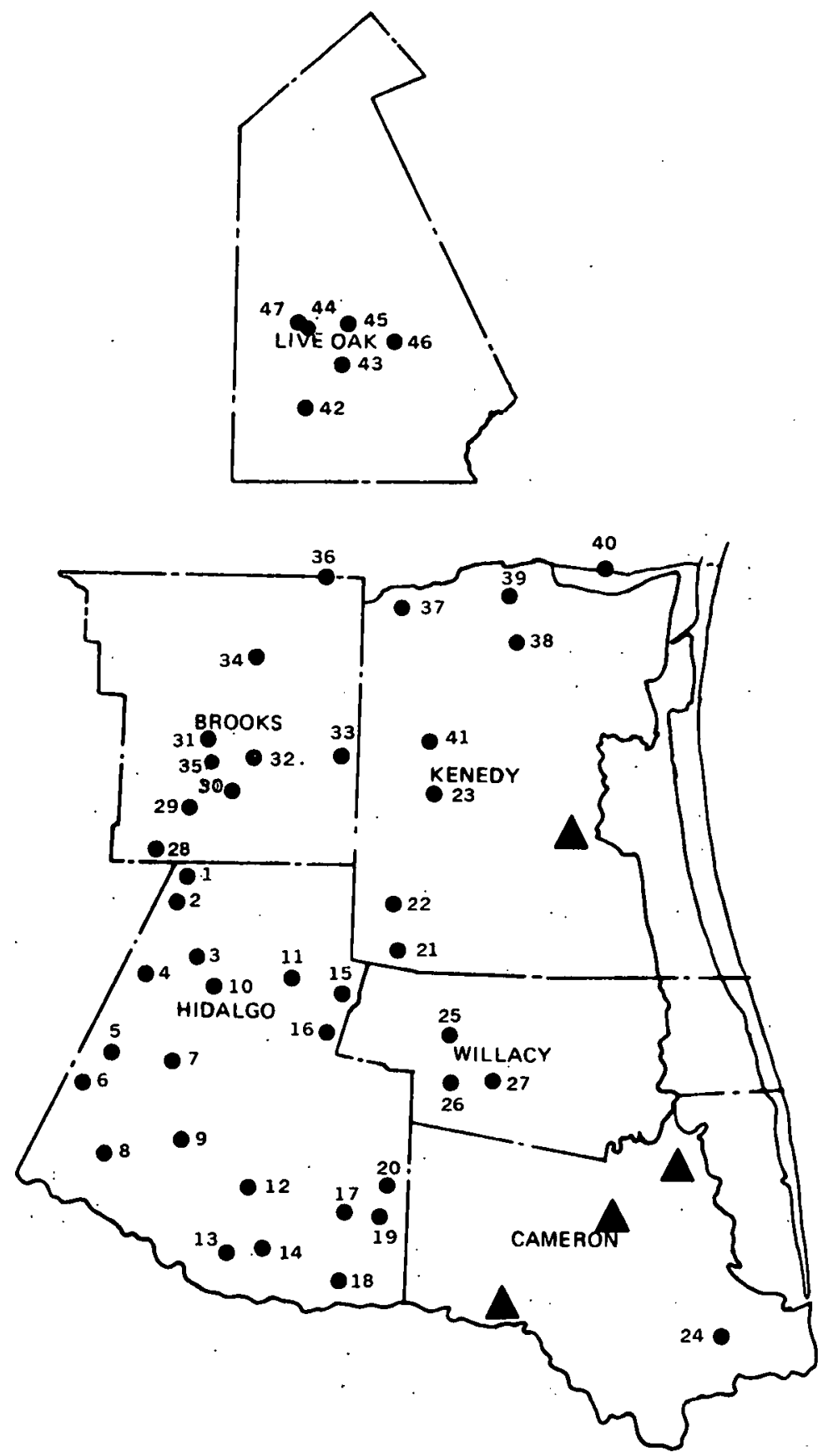

FIGURE 2. GLOPRESSURED GAS FIELDS IDENTIFIED IN STUDY REGION

$\because$ GAS FIELDS

- DRY HOLES OUTSIDE PRODUCING AREA
4. Geologic Investigation

Geologic investigation of each of the identified geopressured fields was undertaken, depending upon the degree of control and other factors. The geologic setting of each of the fields was established, producing horizons were defined and, where possible on the basis of available control, some determination of field size was attempted. In many cases in south Texas, a geopressured field is represented by a single well; but many times these wells are offset by dry holes, imṕroving overall control. Assistance was sought and obtained from producing and operating companies, which provided various types of data. Many south Texas Vicksburg wells (the formation which. was one of the most significant) are located in geologically complex structures. Production from small fault blocks is the rule, and even after many years, experienced geologists disagree on basic features of some of these fields. Nevertheless, sufficient information was obtained to gain a good regional picture, and in the most promising fields from the geothermal standpoint, detailed field geology was established.

\section{Temperature Data}

Bottom-hole temperatures from well logs were obtained from all available logs in each field. A computer program, based on the generally accepted AAPG correction relationship, was written to correct log temperature readings to undisturbed

reservoir temperatures. The program also computes the temperature gradient over each log run, determines the total gradient from the surface to total depth, and calculates the depth of a $150^{\circ} \mathrm{C}\left(300^{\circ} \mathrm{F}\right)$ geotherm, utilizing the gradient at depth. A $190^{\circ} \mathrm{C}\left(375^{\circ} \mathrm{F}\right)$ geothermal surface was also estimated from the data established by the deepest wells in the area. 
TABLE I. GEOPRESSURED GAS FIELDS IN SOUTH TEXAS STUDY AREA, WITH REPRESENTATIVE VALUES ÖF DEPTH GEOPRESSURE, AND $300^{\circ} \mathrm{F}$ GEOTHERM (FIELD NUMBERS APPLY TO FIGURE 2)

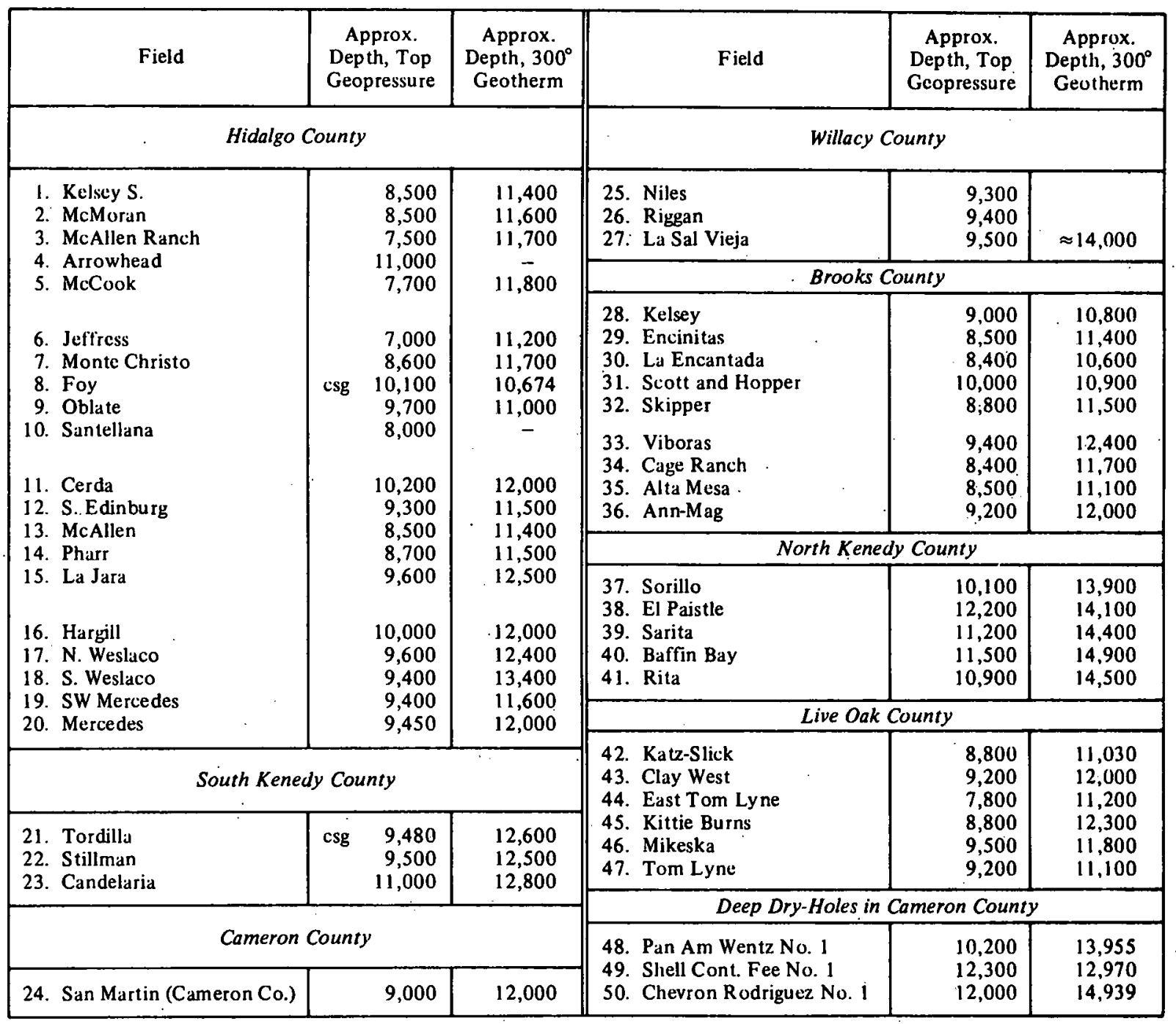

\section{Reservoir Study}

Available reservoir information from each of the fields was obtained from a variety of sources, including Railroad Commission production records, operating company completion data, well test records, and scout cards. The fluid pressure gradient in each of the producing horizons was estimated from the initial bottom hole pressure in the discovery well in each field. From the initial production potential, build-up and drawdown tests, and other available records, the critical reservoir parameters were determined. The general capability of each reservoir to produce fluid was assessed. After preliminary results disclosed that permeability was probably the critical parameter in all south Texas reservoirs, permeability calculations were made in as many wells as possible in each of the producing fields.

\section{Well Test Results}

Details of drill stem and production tests of water zones, inadvertently conducted during completion attempts, were sought, and a number of these was obtained. These results add insight into the water production capability of potential geothermal horizons in the study area. 


\section{Presentation of Results}

The significant results of the study are presented in this report, primarily through a series of regional maps upon which temperature and reservoir information are graphically shown. From these maps the areas of greatest potential can be inferred. Conclusions are drawn and recommendations made, where warranted. 


\section{STUDY RESULTS}

\section{A. Geologic Setting}

South Texas is dominated by a series of regional growth fault systems generally parallel to the coast. At least five of these systems in the study area are considered major. A large number of smaller faults, both parallel and transverse, divide the entire region into a countless number of fault blocks in a pattern of great complexity. In Figure 3, the six counties comprising the study area are outlined on a map showing the major fault systems. The productive geopressured fields identified in the five counties comprising the lower part of the study area are distributed along three of these major faults:

(1) The Frio-Vicksburg flexure in eastern Starr County near the Hidalgo County border, and through central Brooks County,

(2) The Tabasco Fault in southwestern Hidalgo County,

(3) The McAllen Fault, extending northward from Hidalgo through Kenedy County.

In Live Oak County, geopressured production is confined to the area immediately to the east of the large Mirando-Gohlke Fault that stretches from Zapata County into the upper Gulf Coast area.

Each of these major fault zones is comprised of numerous branches. Transverse faults are common, and the faulting generally increases in complexity with depth.

\section{B. Occurrence of Geopressure}

Geopressure was found to occur at relatively uniform depths throughout the study area, with few exceptions. The shallowest recorded occurrence of abnormal pressures in south Texas was found in the Jeffress field near the western boundary of Hidalgo County, at a depth of $6000 \mathrm{ft}$. This shallow depth is unusual, however, and the top of the geopressured zone generally ranges from about $7500 \mathrm{ft}$ along the Frio-Vicksburg flexure (western Hidalgo and central Brooks Counties) to $10,500 \mathrm{ft}$ at the Cameron-Hidalgo and Brooks-Kenedy county lines: The depth of occurrence of geopressure is slightly less uniform in Cameron, Willacy, and Kenedy Counties, but deep area wildcats locate geopressured formations at depths ranging from 10,000 to $13,000 \mathrm{ft}$ in all the wells examined. In the productive area in Live Oak County, geopressure generally occurs at depths below $9000 \mathrm{ft}$. Representative values of the depth of the top of geopressure are shown on the map in Figure 4.

No particular significance has been attached to detailed local variations in the depth of the top of the geopressured zone, since frequently it is coincident with a particular lithologic marker over a fairly large area, and a map of the "top of geopressure" simply defines that boundary. This is typically seen in the case of the " 8500 " sand in the McAllen-Pharr.area and in the Vicksburg "Q" sand in the Jeffress field. Both are blanket sands that always signal the first occurrence of abnormal pressures in these fields. Faulting universally becomes more complex with depth, and for this reason, within the producing zones of interest in deeper horizons, the potential geothermal reservoirs are often confined to small blocks. The continuity of most of these is highly questionable. 


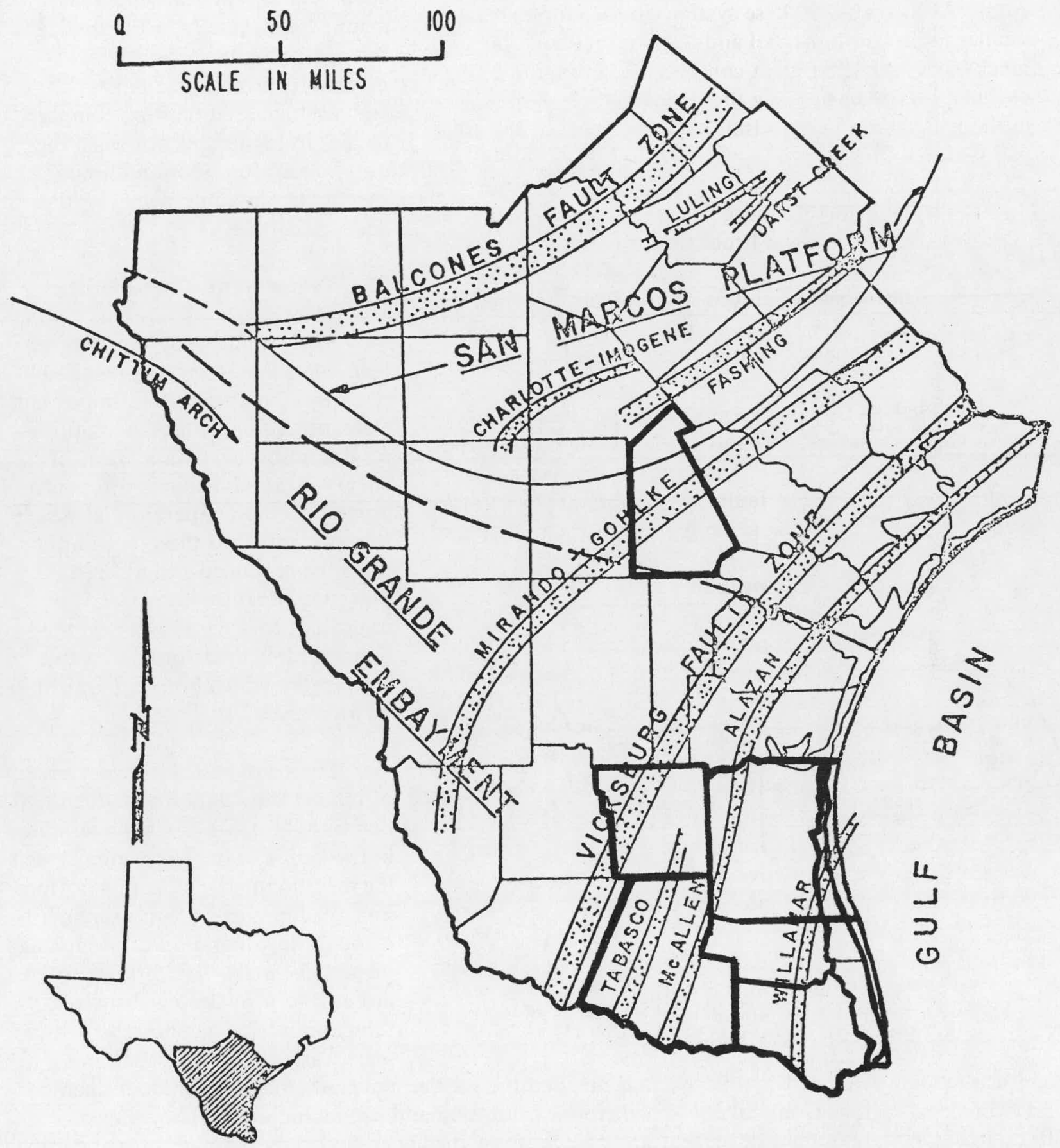

FIGURE 3. SIX-COUNTY STUDY REGION LOCATED IN RELATION TO MAJOR GEOLOGIC FEATURES OF SOUTH TEXAS 

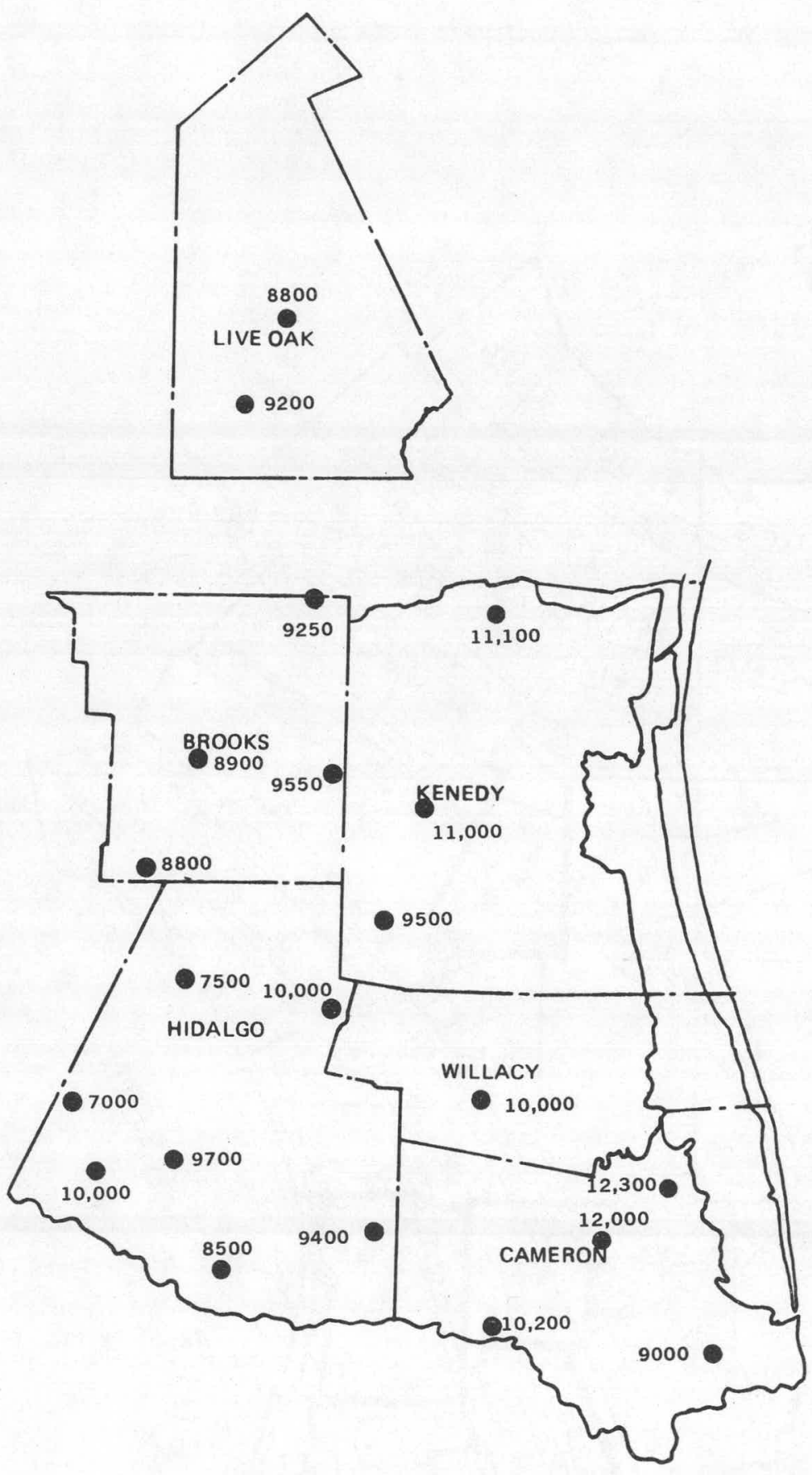

FIGURE 4. DEPTH OF TOP OF GEOPRESSURED ZONE IN REPRESENTATIVE GAS FIELDS IN SOUTH TEXAS
.These points are well illustrated in Figures 5, 6, and 7. Figure 5, a structure map on the top of the " 8500 " (Frio) sand in the McAllen-Pharr area, is in effect also a map of the top of geopressure. The Hansen Sand, mapped structurally in Figure 6, is the approximate top of high geopressure (pressure gradient $\approx 0.9$ ), and the increased faulting compared to that in Figure 5 is obvious. Figure 7 is a cross section through the fields, detailing some of the deeper faulting.

\section{Temperature Characteristics}

The enthalpy of the natural formation water in geopressured reservoirs comprises one important element of the potential usefulness of this resource. As a form of energy, heat has value in direct proportion to the temperature at which it is available, and the rate at which it can be produced and utilized. Since temperature is critical, it is important to accurately assess the temperature characteristics of the strata from which hot water might be produced.

There are basically two sources of temperature data from which temperatures at depth can be determined in the Gulf Coast. These are (1) well $\log$ measurements, including bottomhole readings, and (2) measurements made during operation of producing oil and gas wells. The first reported attempt to investigate subsurface temperatures on a comprehensive scale was published in 1946 in a

significant paper by E. A. Nichols. Nichols mapped the geothermal gradients in the midcontinent and Gulf Coast regions from data obtained from exploration and producing wells. These maps, although incomplete in light of present knowledge, show the generally higher temperatures at depth along the Gulf Coast. A number of noteworthy subsequent studies have been made on the subject of temperature and temperature measurement, including a paper by Schoeppel and Gilarranz (1966), Lewis and Rose (1970), Joyner (1975), and Dowdle and Cobb (1975), among others. Maps of the geothermal gradients of the United States have been published by the American Association of Petroleum Geologists (Kehle, 1971) and others. 


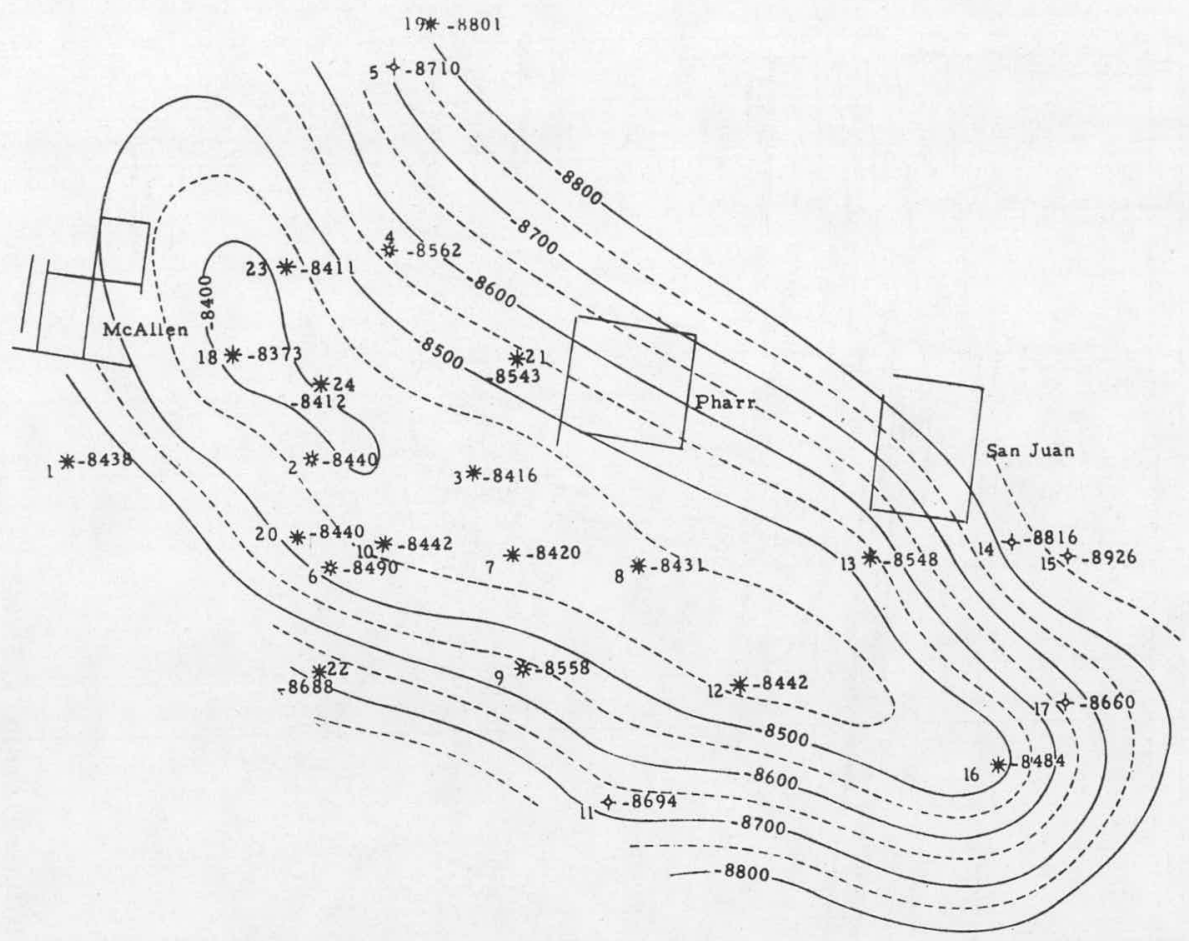

FIGURE 5. STRUCTURE MAP ON TOP OF “ 8500 " SAND (APPROX. TOP GEOPRESSURE) IN MCALLEN-PHARR FIELD, HIDALGO CO., TEXAS

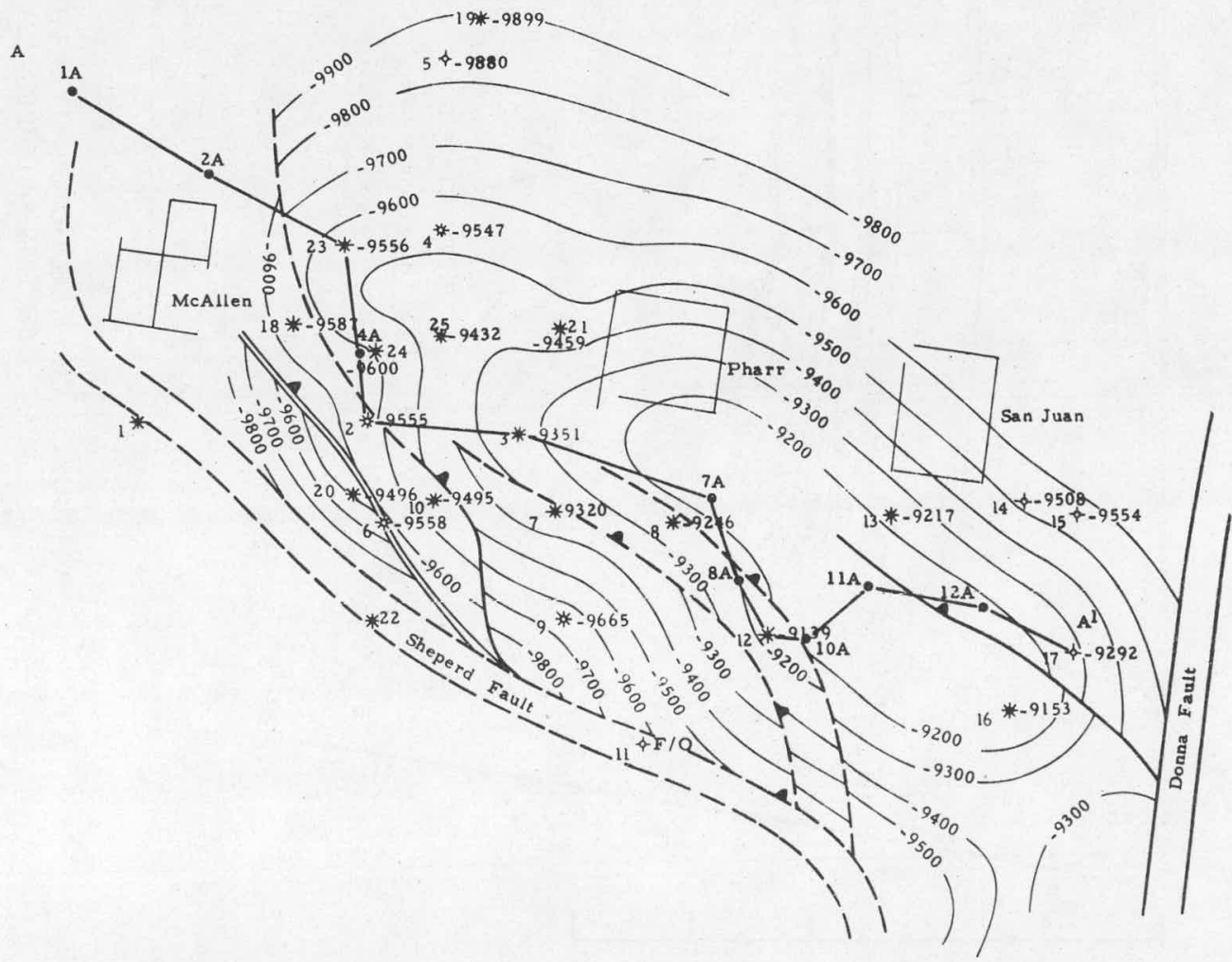

FIGURE 6. STRUCTURE MAP ON TOP OF "HANSEN" SAND, MCALLEN-PHARR FIFLD, APPROX. 800 FT BELOW DATUM ON FIGURE 5, SHOWING INCREASFI) FAULTING WITH DEPTH 


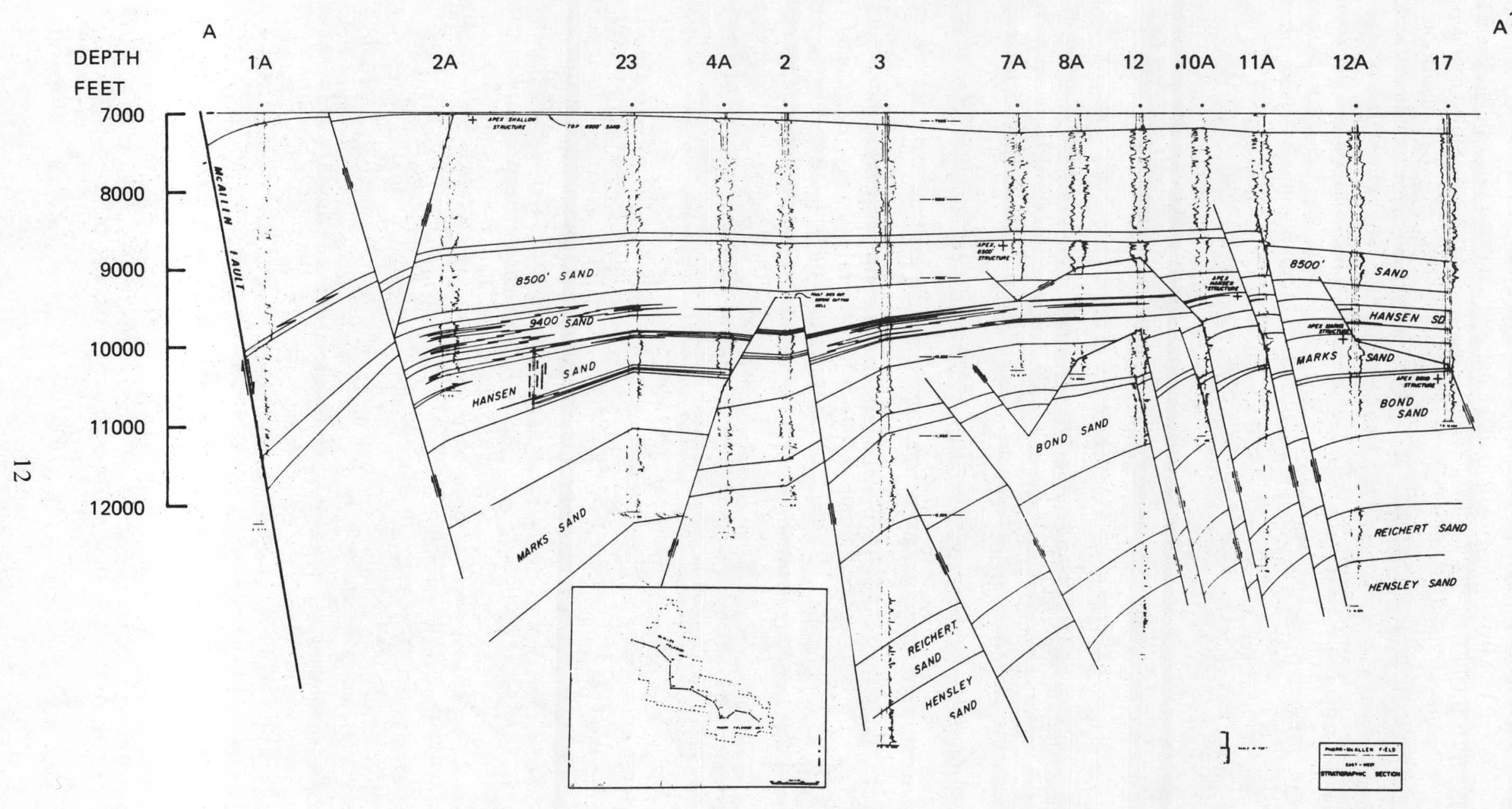

FIGURE 7. CROSS SECTION, MCALLEN-PHARR FIELD, HIDALGO COUNTY, TEXAS SECTION AA ON FIGURE 6 (AFTER COLLINS, 1967) 
The Cull Coast is known to exhibit a thermal gradient ranging from about 1.4 deg per hundred feet to 2.2 deg per hundred lecet over the range of available oil well dalta. All other things being equal, the most promising geolhermal prospects should be al those locitions exhibiting the highest geothermal gradient. Here the depth of the wells would be minimal, and the cost advantage significant. Obviously, the higher temperatures must be available in conjunction with suitable reservoirs as well.

In order to evaluate the temperature potential in the study area, temperature data were obtained from well logs in each of the geopressured fields and from a random sample of dry holes across the region. Temperature readings from log headings were corrected to equilibrium values from the AAPG-developed relation

$$
T_{E}=T_{L}-8.819 \times 10^{-12} D^{3}-2.143 \times 10^{-8} D^{2}+4.375 \times 10^{-3} D-1.018
$$

where

$T_{E}$--Equilibrium temperature, ${ }^{\circ} \mathrm{F}$

$T_{L}$-Electric log bottom-hole temperature, ${ }^{\circ} \mathrm{F}$

$D$ - Depth, ft.

A computer program was written to correct each temperature reading from a log heading to the undisturbed reservoir value. These corrected values were used to calculate the depth of $300^{\circ} \mathrm{F}\left(150^{\circ} \mathrm{C}\right)$ and $375^{\circ} \mathrm{F}\left(190^{\circ} \mathrm{C}\right)$ isogeothermal surfaces from the measured temperature gradients. A representative value of the depth of the $300^{\circ} \mathrm{F}$ surface was assigned for each of the geopressured fields. Only the deepest control points were used to construct the $375^{\circ} . \dot{F}$ surface. Figure 8 shows the locations of the fields in which the $300^{\circ} \mathrm{F}$ geotherm was located at depths less than $11,000 \mathrm{ft}$. The shallowest depth of the $300^{\circ} \mathrm{F}$ point was recorded at $-10,200 \mathrm{ft}$ (subsea) in Jeffress field, in Hidalgo County, although its average depth in the field is slightly below $-11,000 \mathrm{ft}$.

While the $300^{\circ} \mathrm{F}$ geotherm is of interest in showing the general temperature trend, the temperature itself is probably too low for almost all practical purposes, certainly for the generation of power with existing technology. Wilson, et al. (1976) set the minimum useful temperature for power production at $375^{\circ} \mathrm{F}$. This is shown in a general way in Figure 9, in which the hot water required per kWh generated is plotted versus available water temperature (Holt, 1974). So few wells in the Gulf Coast have ever recorded temperatures of this magnitude, that an accurate characterization of this regime is difficult. However, data presented in Figure 10 shed some light on the matter. Temperature plots of deep wells in various parts of south Texas show the general trends to be expected. The highest overall temperature gradient recorded during the study, shown as Curve 1 in the figure, is in the Northeast Thompsonville field located in Jim Hogg County (actually outside the study area). Undisturbed formation (Wilcox) temperature calculated from recorded bottom hole readings in that field, is $390^{\circ} \mathrm{F}$ at $14,000 \mathrm{ft}$. Both Live Oak and western Hidalgo Counties also have fields with temperature gradients almost as high.

On the map in Figure 11 it can be seen that $375^{\circ} \mathrm{F}$ temperatures, from deep-well measurements in the region, occur at depths from 14,000 ft (southwestern Live Oak County) to more than 20,000 ft in central Cameron and eastern Kenedy Counties. The deepest well identified in the study area is a 20,000-ft dry wildcat near the Candelaria field (Kenedy County) with an equilibrium temperature of $375^{\circ} \mathrm{F}$ at $18,000 \mathrm{ft}$. An $18,500-\mathrm{ft}$ well in central Cameron County failed to record temperatures above $350^{\circ} \mathrm{F}$. 

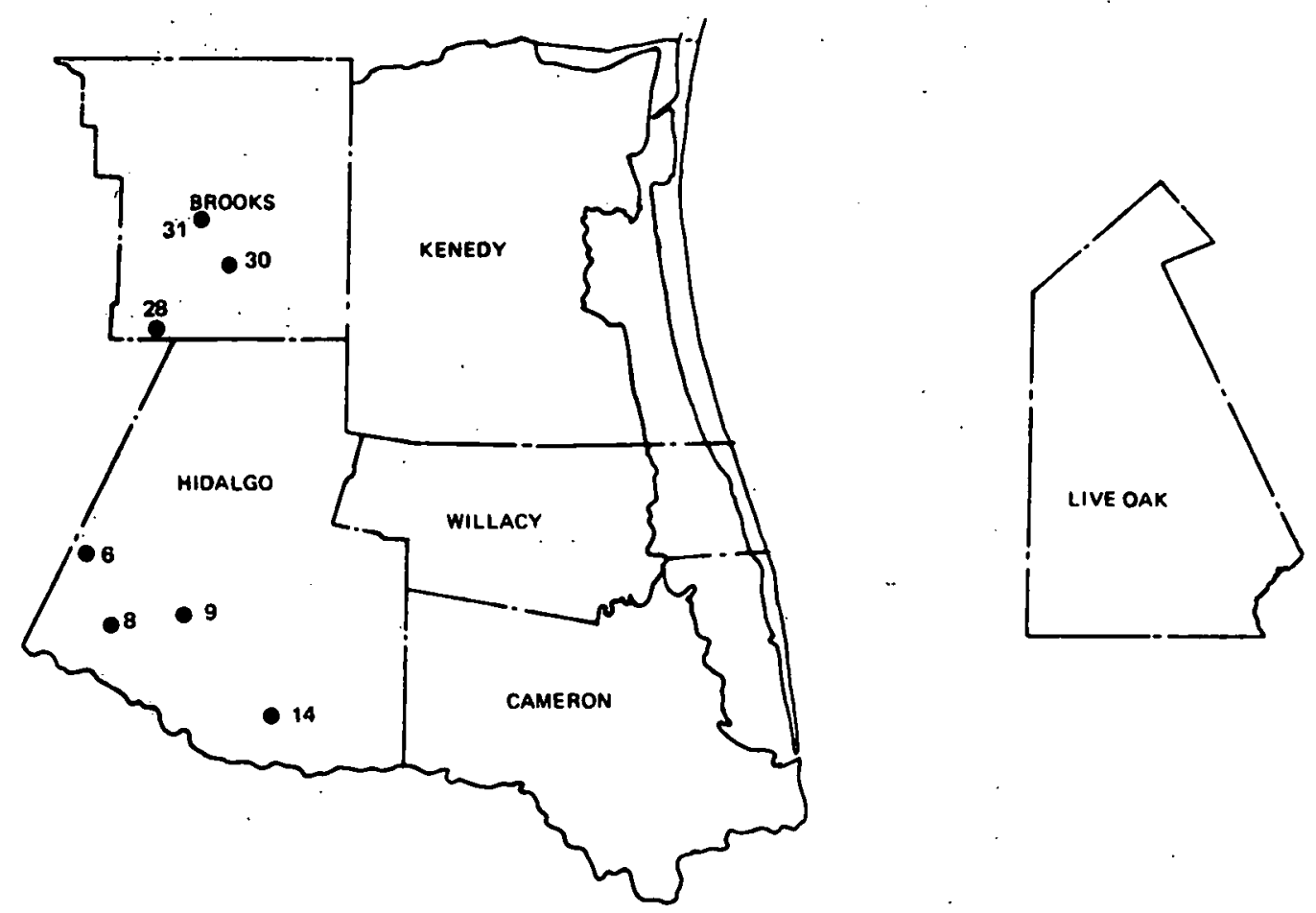

FIGURE 8. FIELDS WITH DEPTH OF $300^{\circ} \mathrm{l}$ ( $\left(150^{\circ} \mathrm{C}\right)$ GEOTHERM LESS THAN 11,000 FEET

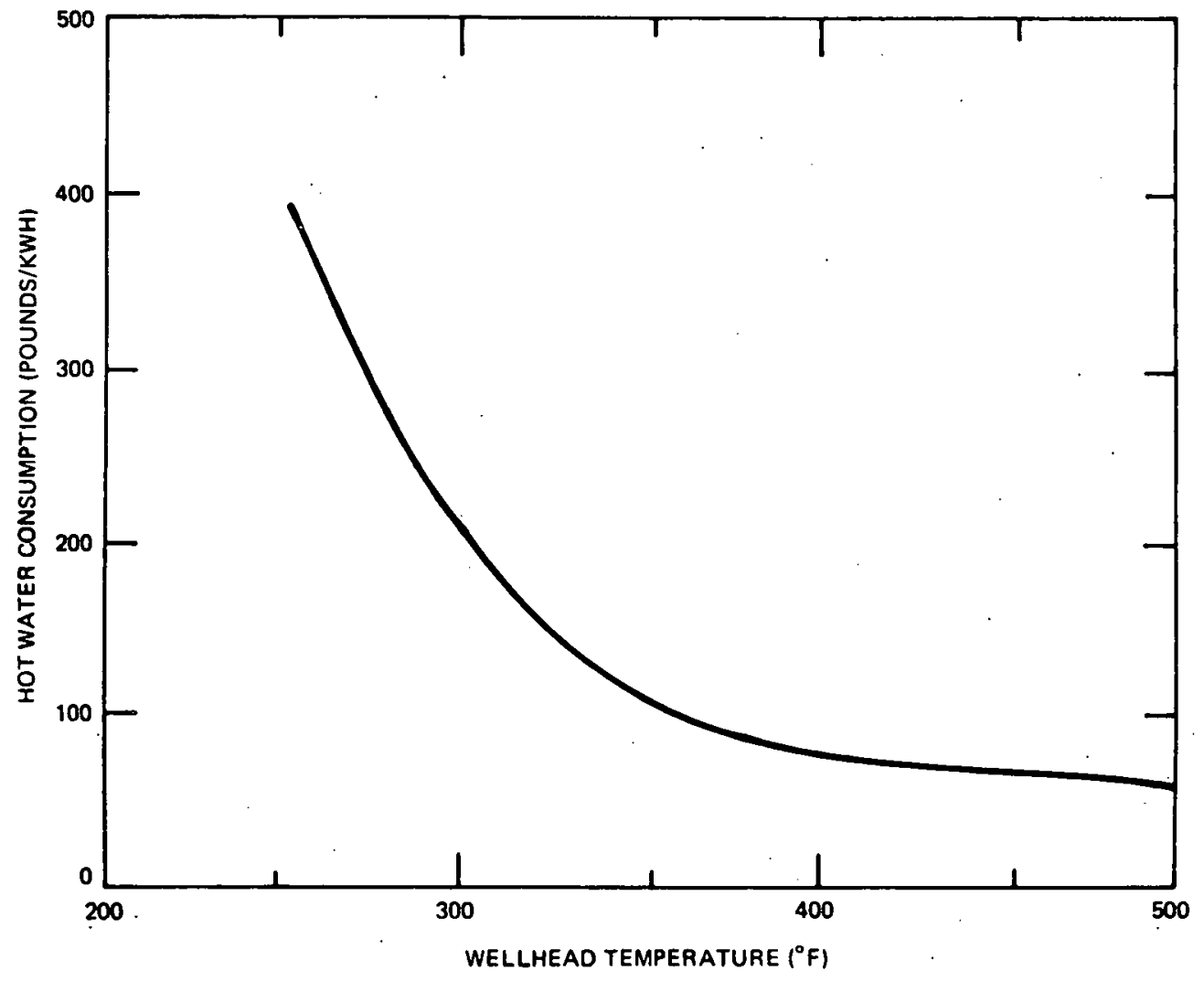

FIGURE 9. EIFECT OF WELLHEAD TEMPERATURE ON HOT WATER CONSUMPTION FOR POWER PRODUCTION (IIOLT, 1974) 


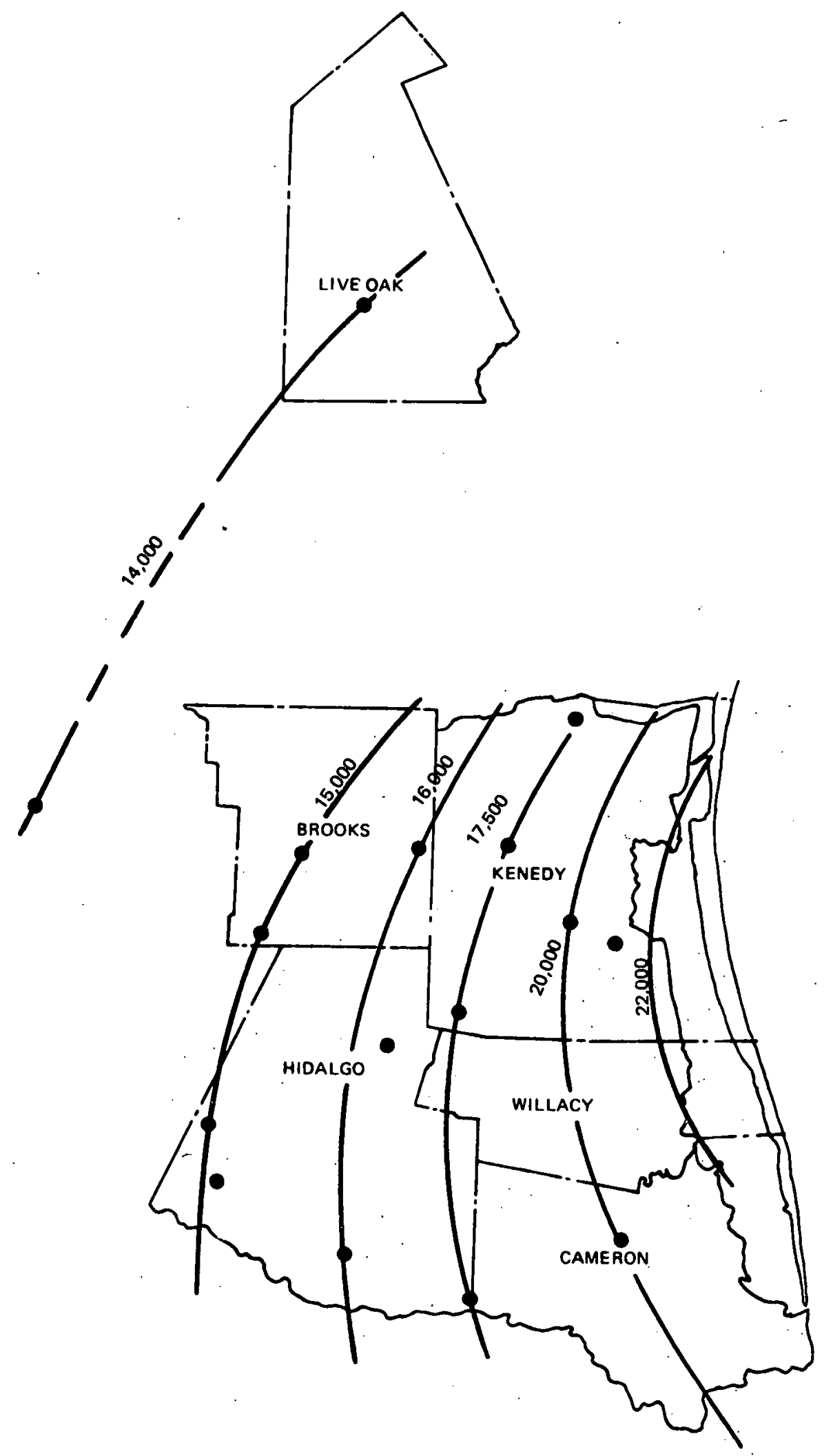

FIGURE 11. APPROXIMATE DEPTH OF $375^{\circ} \mathrm{F}\left(190^{\circ} \mathrm{C}\right)$ GEOTHERMAL SURFACE 


\section{Geologic Temperature Horizons}

With the possible exception (unknown) of the very deepest part of the basin in castern Cameron County, temperatures as high as $375^{\circ}$ I: probably do not occur in the firio formation, but in Vicksburg or deeper sediments. In southwestern Live Oak County, high temperatures are confined to the Wilcox and deeper strata.

There is undoubtedly finer structure to the $375^{\circ} \mathrm{F}$ geothermal surface than is shown in Figure 11, estimated from the few deep control points in the region. Over most of the mapped area outside Live Oak County, temperatures high enough to be of geothermal interest occur in the Vicksburg formation. For this reason, great attention must be paid to potential reservoirs within this zone. Areas of extensive sand deposition in the Vicksburg are limited, and generally occur along and to the east of the Frio-Vicksburg flexure, and in northern Kenedy County. It is significant that the shallowest $375^{\circ} \mathrm{F}$ geotherm located in the Rio Grande Valley area (not including Live Oak County) is coincident with the region (although unfortunately not the depth) in which some of the best Vicksburg sand development occurs.

\section{Detailed Field Temperature Studies}

Detailed study of the localized temperature variations within geopressured gas fields was undertaken in four fields located in a promising area near the McAllen fault. This is the location of extensive deltaic Frio and Vicksburg sand deposition, and includes the Edinburg, South Edinburg, McAllen, and Pharr gas fields in lower Hidalgo County. From well log bottom-hole temperatures, corrected to equilibrium values, a $300^{\circ} \mathrm{F}$ geothermal surface was mapped and is shown in Figure 12. It is interesting to note that this isothermal surface is warped downward over the structural highs representing Edinburg, South Edinburg, and Pharr, but is warped upward over the McAllen structure, where it is, no doubt, dominated by a local branch of the transverse Shepherd fault. The minimum depth of the $300^{\circ} \mathrm{F}$ surface appears to center over the barren area between the fields, between the city of Edinburg and the city of San Juan. The complexity of the temperature profile in the area doubtless reflects the countless major and minor growth faults that characterize the region. The study illustrates the great complexity of the entire subject of temperature and geopressure, neither of which conform to any simple, generalized explanations.

Figure 13 shows a plot of temperature versus depth of a deep well in McAllen Ranch field, a highly productive Vicksburg field near the western Hidalgo border. The relatively large number of logging runs made on this well permit the wide variations in localized temperature gradients along the well bore to be observed. These are plotted in conjunction with shale resistivity values, which may be indicative of pressure. The increase in temperature gradient corresponding to the onset of high pressure lends credence to the theory that the high temperatures associated with abnormal pressures are caused by the insulating properties of under-compacted shale beds.

A matter of further interest in this figure is shown by the behavior of the temperature gradient as progressively deeper undercompacted shales are encountered. The maximum temperature gradient occurs immediately below the top of geopressure, and each major shale bed below produces an additional change in gradient. However, each new slope becomes less pronounced, and approaches the normal gradient asymptotically. Presumably if one went to sufficient depth, the gradient above the geopressured zone would be reestablished. In McAllen Ranch, that gradient is about 1.8 deg per hundred feet. Temperature projections made from the gradient below and near the top of geopressure can be misleading, and should not be attempted for depth projections greater than a thousand feet or so. In the well from which Figure 12 was prepared, the gradient at 10,000 $\mathrm{ft}$, used to project the temperature at $14,000 \mathrm{ft}$, would have overestimated the temperature by more than $100^{\circ} \mathrm{F}$. 


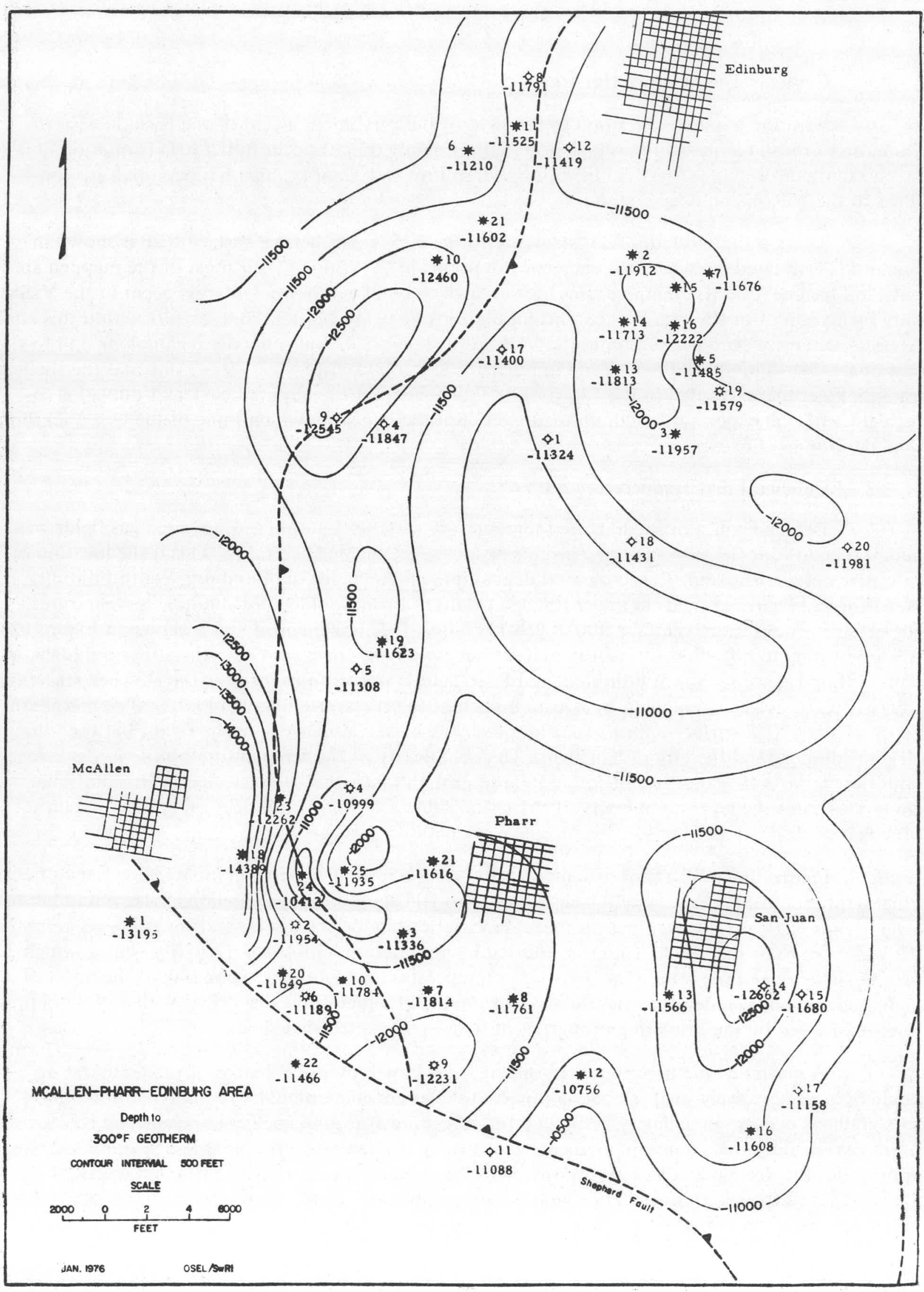

IFIGURE 12. MCALLEN-PIARR-EDINBURG AREA 


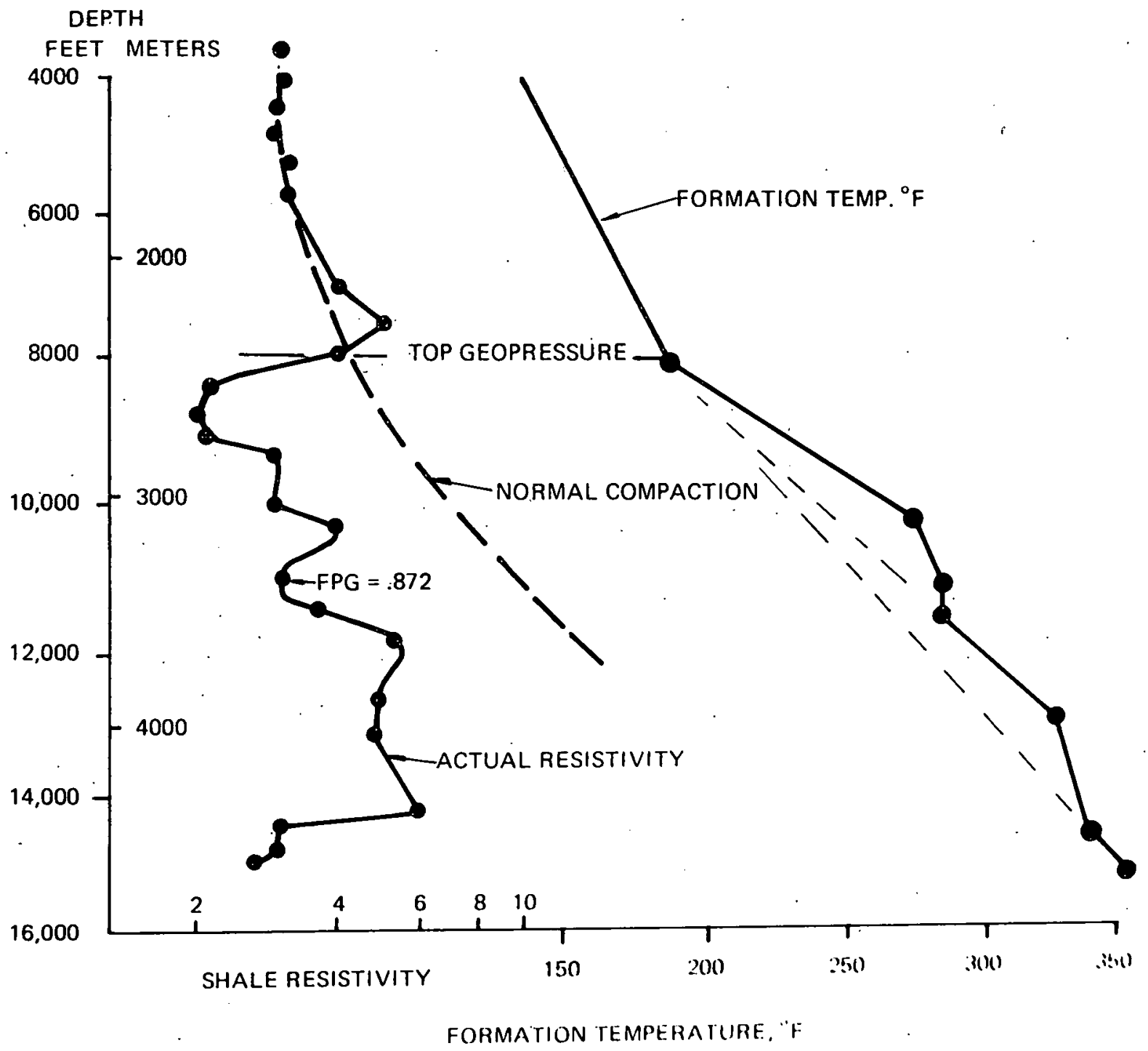

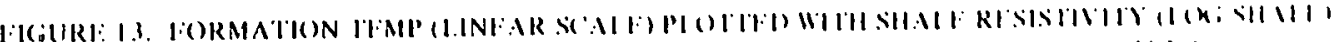

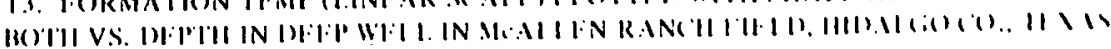


The temperature trend in Brooks County closely parallels that in western Hidalgo County. The central Brooks County fields represent Vicksburg production from deposition dominated by the Frio-Vicksburg flexure. The depth of the $300^{\circ} \mathrm{F}$ geotherm typically ranges from 10,000 to $11,000 \mathrm{ft}$ near the fault, deepening to 12,000 to $13,000 \mathrm{ft}$ near the Kenedy County border.

Temperatures in Kenedy are generally lower than in Hidalgo and Brooks Counties, with the $300^{\circ} \mathrm{F}$ geotherm ranging from $13,000 \mathrm{ft}$ in Candelaria field to $17,000 \mathrm{ft}$ in Tajos.

\section{Reservoir Characteristics}

\section{Fluid Deliverability.}

Perhaps the most significant question surrounding exploitation of the geopressure-geothermal resource is the frequency with which suitable reservoirs may be anticipated to occur. This question involves the deliverability of a reservoir for geothermal fluid at adequate flow rates and with main-. tenance of pressure over relatively long periods of time. Deliverability is of particular significance at the depths necessary to provide temperatures sufficiently high to warrant the equipment investment required to recover useful quantities of heat. While answers to the deliverability question involve the determination of rather complex formation parameters, years of experience in the production of petroleum, particularly in the region of this study, can shed considerable light on the problem.

The fundamental concept upon which exploitation of this resource is based is the continuous production of large volumes of water (tens of thousands of barrels per day per well) from deep, abnormally pressured reservoir rock. Whether or not this is a tractable undertaking depends upon several fundamental reservoir parameters which are well within the province of engineering study.

In order to produce water, a reservoir must have two coincident properties: first, it must have sufficient porosity (void space) to contain the water; and second, it must have sufficient permeability (the ability to flow fluid through the pore space) to allow the water to flow at high rates:

In addition to porosity and permeability, fluid flow from a well drilled in to a subsurface reservoir is a function of (1) reservoir pressure; (2) flowing pressure at the well bore; (3) viscosity of the fluid; (4) reservoir thickness; (5) size of the well bore; and (6) size or areal extent of the reservoir.

The absolute permeability of a reservoir is a function of the rock matrix and not of fluid type, provided that only a single fluid is involved. Since all the geopressured fields under study in the south Texas area are gas fields, deliverability determinations have been based on the production of gas. Long experience with a wide range of producing formations has produced mathematical relationships that allow the performance of a gas well to be predicted from the reservoir parameters. Conversely, knowledge of production performance permits reservoir parameters to be inferred. These relationships and their derivation are at the heart of modern reservoir engineering. equation

The rate of flow of gas from a gas well in a reservoir is given by the following empirical

$$
Q_{b}=\frac{19.88 k h\left(P_{e}{ }^{2}-P_{w}{ }^{2}\right)}{\mu P b \ln \frac{r_{e}}{r_{w}}}
$$


where

$Q_{b} \quad-\mathrm{Cu} \mathrm{ft}$ gas/day at base pressure $P_{b}$

$k$-..-Permeability Darcies

$h$-Formation thickness, $\mathrm{ft}$.

$P_{c} \quad$-Formation pressure at boundary distance $r_{e}$, psi

$P_{w} \quad$-Formation pressure flowing, at well, psi

$r_{c} \quad$-Radius of reservoir, $\mathrm{ft}$

$r_{w} \quad$-Radius of well, $\mathrm{ft}$

$\mu \quad-$ Viscosity of the gas.

This expression involves the factor $k h$, the concept of "permeability $\times$ feet." In south Texas, permeability was found to be the critical parameter in determining the producibility of known geopressured formations. Where permeability is low, it can only be compensated by increased formation thickness.

The rate of flow of water from a reservoir.is given by a second equation,

$$
Q=7.082 \frac{k h\left(P_{e}-P_{w}\right)}{\mu \ln \frac{r_{e}}{r_{w}}}
$$

where

$Q-\mathrm{bbl} / \mathrm{day}$. It involves the same factor $k h$.

\section{Reservoir Parameters}

In the following paragraphs, each of the significant reservoir parameters is briefly examined.

\section{a. Reservoir Pressure}

The reservoir boundary pressure $\left(P_{e}\right.$ in Eqs. 2 and 3$)$ is a function of its depth, and the degree to which it is sealed from its surroundings. Geopressured reservoirs are, by definition, under greater than hydrostatic pressure. In order for abnormal pressures to exist, aquifers must be sealed by faulting, stratigraphy, or both. Geopressure is believed to be a dynamic condition; that is, sealing of such aquifers is relative, with some leakage continually tending to equalize the pressure over geologic time. In general, the pressure due to the weight of overlying rock averages about 1 psi per foot of depth. While reservoirs with fluid pressure gradients greater than 1 psi per foot have been reported, they are not common. South Texas-producing reservoirs all were found to exhibit fluid pressure gradients less than 0.95 .

\section{b. Pressure at the Well Bore (Bottom-Hole Flowing Pressure)}

As a well is flowed, the pressure near the well bore is reduced. The higher the rate of flow, the lower the well-bore pressure ( $P_{w}$ in Eqs. 2 and 3). However, the minimum flowing pressure is set by the hydrostatic head of the fluid in the pipe and by the friction of the fluid moving up the well. The hydrostatic head depends on the density of the fluid and the height 
of the column. The possible evolution of gas from produced water will lower the pressure at the bottom of the well, due to the reduction in overall density of the fluid.

Pressure drop in the well bore caused by friction is a function of the diameter of the well and rate at which the fluid moves.

Pressure drop in the formation itself, caused by flowing the well, is known as "drawdown." For a given well (size and depth); drawdown will influence the maximum rate at which the well can be flowed.

\section{c. Viscosity of the Water}

The rate of flow of water from a reservoir is an inverse function of viscosity, which in turn depends primarily on the reservoir temperature. In general, water viscosity decreases with temperature, and at $300^{\circ} \mathrm{F}$, its viscosity is about $0.2 \mathrm{cp}$.

\section{d. Thickness}

The thickness influences the rate of flow in a straightforward manner: the thicker the producing interval, the greater the potential of the reservoir to produce fluid. The thickness is also a factor in controlling the effective volume of the reservoir, which in turn influences the pressure performance of the reservoir as fluid is withdrawn. A large reservoir will lose pressure more slowly as fluids are withdrawn than will a smaller one.

\section{e. Radius of the Well Bore}

A well bore with a large radius will permit fluids to be withdrawn at a higher rate than from a well with a small radius. Hydraulic fracturing has the effect of increasing the effective radius; however, the term appears as a logarithmic one in the deliverability equations (Eqs. 2 and 3), signifying only limited effect due to change of this parameter.

\section{f. Reservoir Area}

The areal extent of a reservoir affects the pressure as fluid is withdrawn, and finally determines the producing life. As the pressure is reduced, the rate at which fluid can be withdrawn is also reduced. The pressure in a large reservoir is maintained at a high value longer than pressure in a smaller one.

Neither the well radius nor the size of the reservoir have a profound effect on the initial flow rate, since each affects the flow as a logarithmic function of their ratio. However, in the determination of reservoir life, size is of great importance.

\section{g. Porosity}

Porosity, a measure of the relative void space within a rock matrix, is determined by a number of factors including grain size, quantity and type of precipitates, presence of clay, and formation pressure. The effect of pressure is generally to reduce effective pore space. The hydrostatic pressure of fluid in the pore space assists in balancing part of the overburden pressure; if fluid is withdrawn, the formation can be expected to compress by an amount related to the compressibility of water, or approximately $10^{-6}$ per psi. Compressibility of a rock matrix is not the same for all 
reservoir rocks, and in addition maly vary with the pressure. In abnormally pressured reservoirs, one can expect the compressibility of a reservoir to be greater than in a normally pressured one: As fluid is withdrawn and pressure of the remaining fluid reduced, the pore volume will become smaller and the rate of pore volume change will be reduced. There are few, if any, published results of measurements of the compressibility of geopressured reservoirs, and no such results have been identified for south Texas reservoirs. Knowledge of this parameter is needed before the performance of geopressured reservoirs can be fully assessed.

\section{h. Permeability}

The factor most directly affecting the deliverability of a given reservoir is its permeability. or the ability to allow the passage of fluid through the pore space. Both porosity and permeability are functions of rock texture, but permeability is directly affected by the type of porosity in the rock. In sands, high values of porosity almost always signify high permeability because the large pore channels associated with high porosity permit the fluids to pass more easily through the rock. Other factors affecting permeability include "tortuosity," and gas or water saturation. While permeability is not a function of fluid type provided a single fluid is involved, if gas is released from solution, its presence within the pore space will retard the movement of water, and the effective permeability to the flow of water will be reduced. In general, the more gas that is evolved from solution, the lower will be the permeability to the flow of water.

Flowing water through an otherwise undisturbed reservoir may alter the physical properties of the rock and reduce permeability. Flowing a water well can cause clay particles in the matrix to swell and reduce the flow, or may actually cause clays and other solid particles to be released from the matrix itself, altering the porosity and the available flow paths. Chemical content of the formation water may influence the reaction of the water with reservoir rock. The permeability of a reservoir is a complex function of depth, with increased overburden pressure tending to reduce both porosity and potential flow through the pore space. In geopressured formations, the permeability may initially be adequate, but as fluid is withdrawn and the pressure is reduced, the pores may tend to close, reducing permeability. Results of investigations of this effect in geopressured formations have not been reported in the literature and work is needed. The general subject of the direct effect of pressure on permeability has been discussed in detail by Fatt and Davis (1952), McLatchie, et al. (1958), Vairogs, et al. (1971), Fatt (1953), and Thomas and Ward (1972). In Figure 14 is shown an (unpublished) plot of permeability, measured in the laboratory as a function of confining pressure of

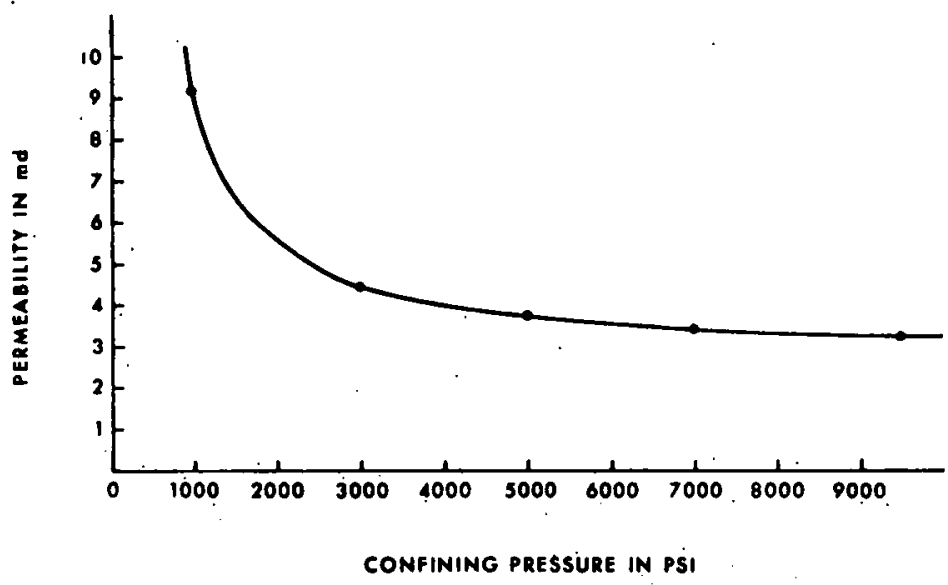

FIGURE 14. REDUCTION IN PERMEABILITY AS A FUNCTION OF CONFINING PRESSURE $\mathrm{K}_{\wedge 1 \mathrm{M}}=367 \mathrm{MD}$ a core plug from a geopressured California well. The permeability was reduced from $367 \mathrm{md}$ (unconfined) to less than $4 \mathrm{md}$ at $4000 \mathrm{psi}$. a reduction of two orders of magnitude.

\section{E. Permeability of South Texas Gas Reservoirs}

Because of the significance of permeability to the performance of a reservoir, and because the permeability of south Texas petroleum reservoirs generally is known to be low, considerable effort was spent in determining permeability valués of the geopressured gas 
reservoirs in the study region. This turned out to be one of the most significant tasks in the study, and one of the most revealing in terms of the overall assessment of the geothermal potential.

The permeability of a reservoir is normally determined in one of three ways: (1) from core analysis; (2) from behavior of a producing well during flow tests, and (3) from pressure buildup and drawdown tests. Probably the most reliable indication of permeability is obtained from buildup and drawdown tests. Frequently, however, these are not available. Somewhat less accurate but very meaningful determinations can be made from flow tests. Regulations of the Texas Railroad Commission require that completion flow tests and periodic production flow tests be performed and the results filed with the Railroad Commission, where they become matters of public record. For purposes of regional evaluation, they are extremely useful for determining the deliverability of a producing horizon. The results are in the form of an "absolute open-flow potential," calculated from a series of flow tests conducted at different flow rates.

Utilizing Eq. 2 on page 20 for the deliverability of a gas well, calculations of the factor " $k h$ " (permeability $X$ thickness) for representative wells from each of the producing fields in the. study region were made. A sand-count was then made in each reservoir, and a final calculation of permeability obtained. Permeability values were averiged over a field where appropriate, or separately determined where different producing horizons were involved. These results are summarized in the following paragraphs and in Figures 15 through 22, showing representative permeability values in the fields grouped according to their geographic location, and generally similar geologic settings.

\section{Western Hidalgo-Central Brooks County}

Six deep gas fields located in western Hidalgo County and eight fields through central Brooks County are located along and to the east of the Frio-Vicksburg flexure, a large major growth fault system that forms the western boundary of geopressure in the study region. Representative permeability values calculated for the six deep fields in this area of Hidalgo County are shown on the map in Figure 15. The eight geopressured fields along the same fault system in central Brooks County are shown in Figure 16. Permeability

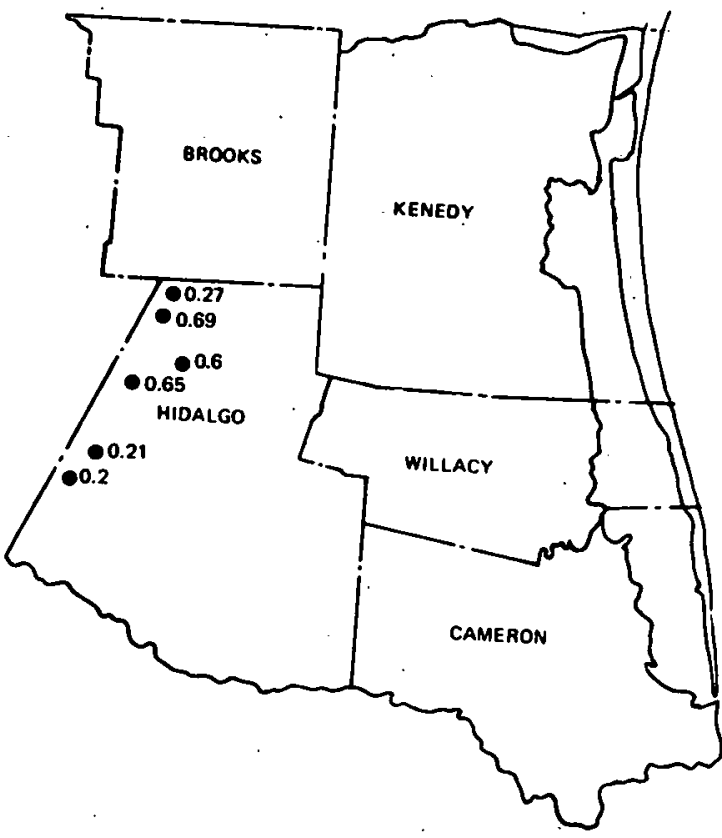

IIICURE 1S. RI:PRISSI:NI'ATIVI: PIIRMI:ABIIITY.MI) VIC.KSIBURC: I:AUI.T ARI:A, IIII)AIC, () (C) values in all these fields are consistently less than $2.0 \mathrm{md}$, ranging from a low of $0.05 \mathrm{md}$ to a high of $1.9 \mathrm{md}$. These calculated permeability values are confirmed by a complete suite of cores from a well in the McAllen Ranch field in $\mathrm{Hi}$ dalgo County. The results were provided by the Shell Oil Company and are included in Appendix B. This well, diamond cored continuously from 10,600 to $12,600 \mathrm{ft}$, showed average core permeabilities in the sands of $0.1 \mathrm{md}$. There were only 13 samples in the entire suite of cores with permeabilities above 10 md: The highest permeability recorded was 39 md over a $0.5-\mathrm{ft}$ core interval. 


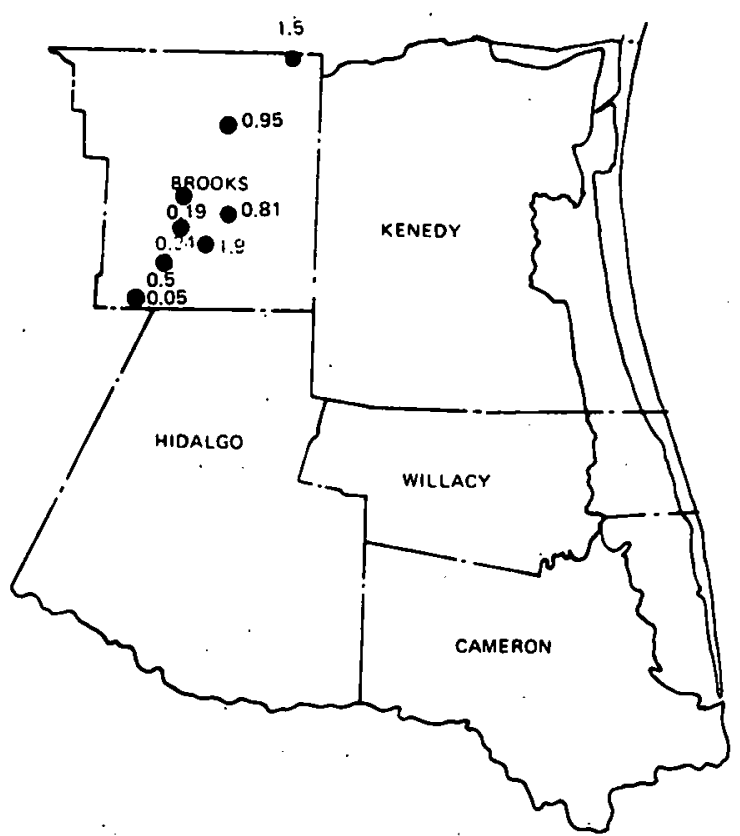

FIGURE 16. REPRESENTATIVI: PL:RMEABILITY;MI) VICKSBURG I:AULT ARI:A, BROOKS CO

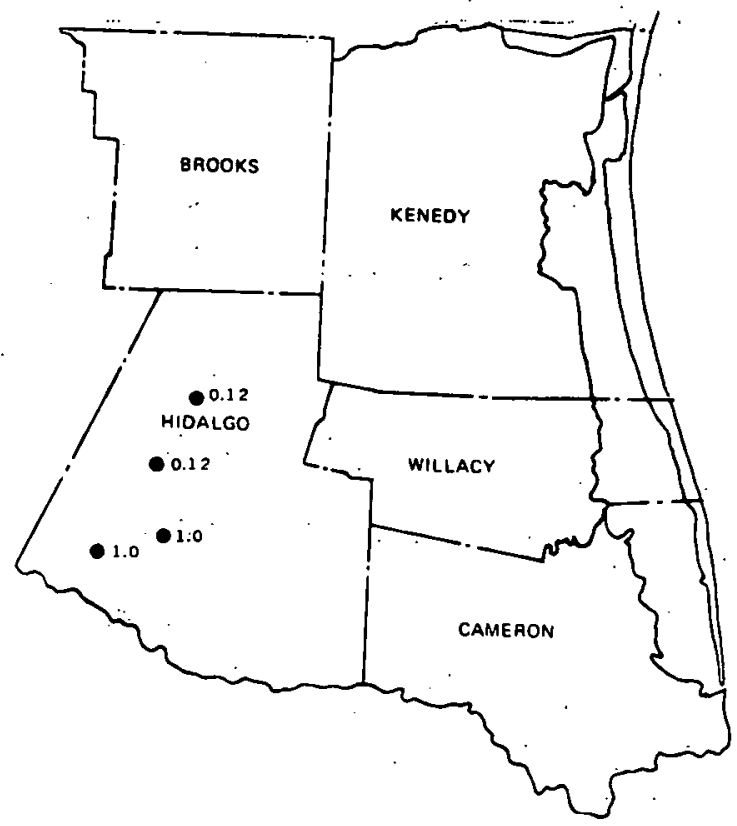

I:ICURI: 17. RI:PRI:SI:NTATIVI: PERMIEABILITY, MI) TABASCO I:AULT ARLA, HIDALGO CO.

2. Hidalgo County-Tabasco Fault Area

Four geopressured gas fields in sou thwestern Hidalgo County were located along the trend generally defined by the Tabasco fault. Locations of these fields, with representative values of calculated permeability, are shown in Figure 17. Permeability here is also in the range of 1.0 to $0.1 \mathrm{md}$.

\section{Hidalgo County-Lower McAllen Fault}

Seven fields in the southeastern part of Hidalgo County lie along the lower part of the major McAllen fault and the nearby Weslaco fault. Permeability values in representative rescrvoirs in these fields are shown in Figure 18. The highest permeability noted was $2 \mathrm{md}$, and the lowest $0.5 \mathrm{md}$.

\section{Hidalgo County, South- western Kenedy County- Upper McAllen Fault Zone}

The continuation of the McAllen fault to the north roughly defincs the locations of the five gas fields shown on the malp in Figure 19. Representative values of reservoirs in these fields range from 0.9 to $8.0 \mathrm{md}$.

\section{Eastern Brooks County, Northern Kenedy County}

Seven fields in the northeastern part of the study region exhibit
in Figure 20, with representative persomewhat similar characteristics and their locations are shown in Figure 20, with representative permeability values. These range from 0.12 to $2.2 \mathrm{md}$.

\section{Cameron County, Willacy County}

The four fields making up the geopressured production in Cameron and Willacy Counties are located on the map in Figure 21. Permeability values range from $0.07 \mathrm{md}$ in La Sal Vieja field in Willacy County to $24.0 \mathrm{md}$ in the Riggan field. The latter value was the highest calculated in any field in the study region. Riggan is a shallow Frio ficld $(9400 \mathrm{ft})$ with a fluid pressure gradient of 0.58 , and a temperature of approximately $200^{\circ} \mathrm{F}$. 


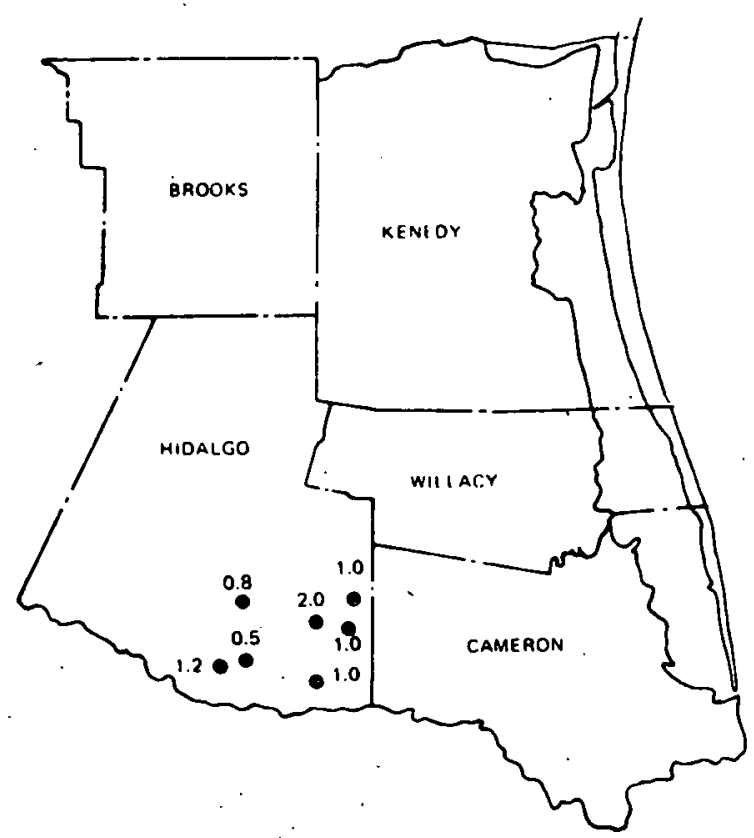

FIGURE 18. REPRESENT ATIVE PERMEABILITY, MD LOWER MCALLEN FAULT AREA, HIDALGO CO.

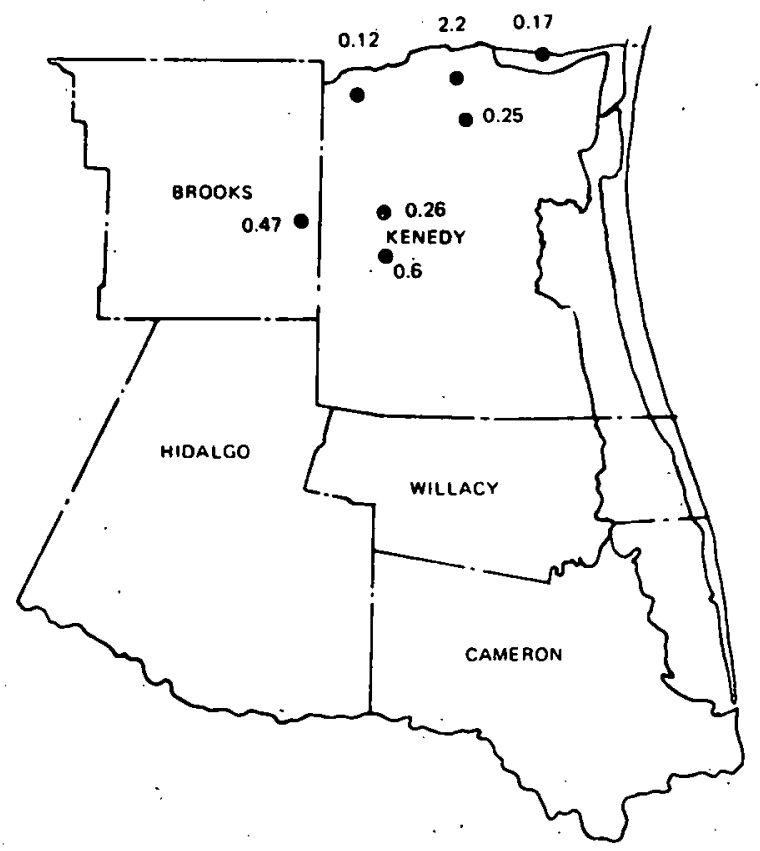

FIGURE 20. REPRESENTATIVE PERMEABILITY, MD KENEDY-BROOKS COUNTIES

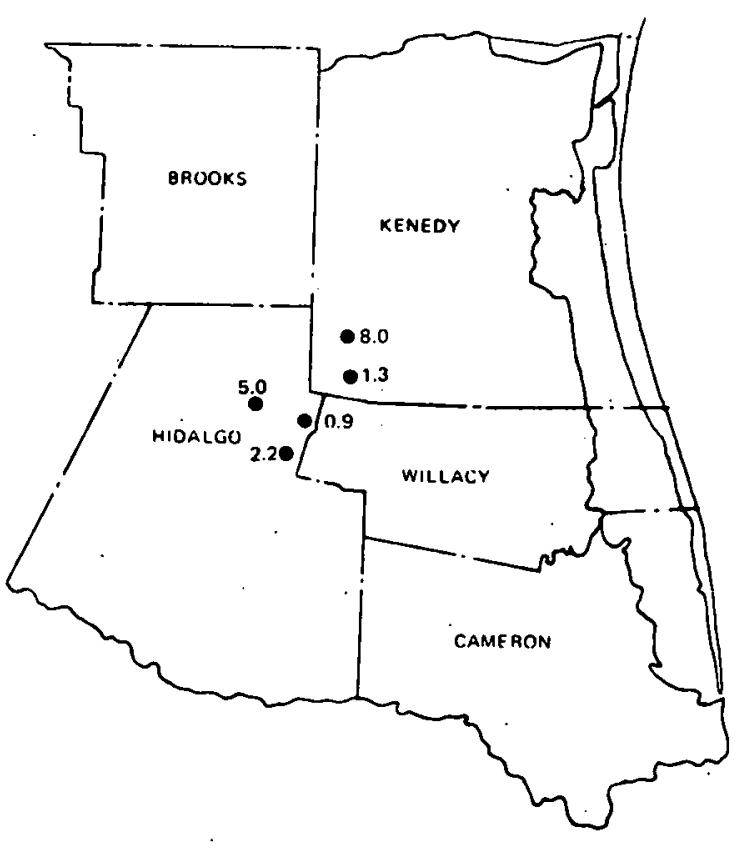

FIGURE 19. REPRESENTATIVE PERMEABILITY, MD UPPER MCALLEN FAULT, HIDALGO-KENEDY COUNTIES

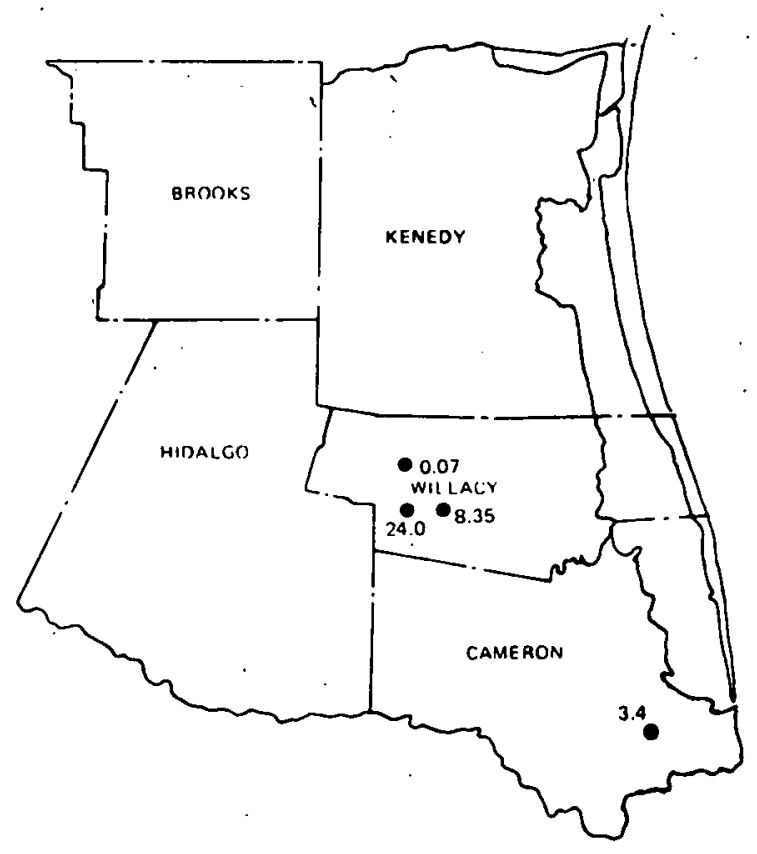

FIGURE 21. REPRESENTATIVE PERMĖABILITY, MD CAMERON-WILLACY COUNTIES 


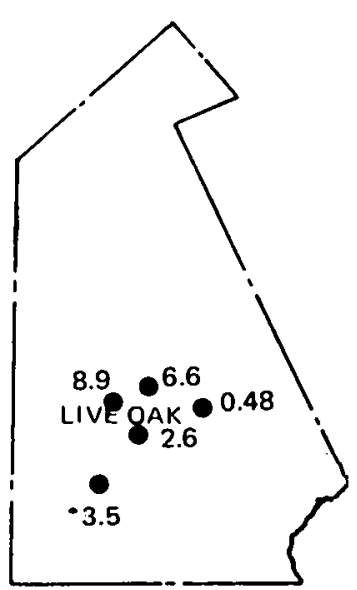

FIGURE 22. REPRESENTATIVE PERMEABILITY, MD LIVE OAK COUNTY

\section{Live Oak County}

Wilcox gas reservoirs in Live Oak County exhibit ellective permeabilities from 0.48 to $8.9 \mathrm{md}$, and the locations of these fields are shown in Figure 22. The best permeability found in a reservoir with fairly good temperature was located in Live Oak County. The lower Wilcox production in the Tom Lyne field exhibits permeability as high as $8.9 \mathrm{md}$ at $11,500 \mathrm{ft}$, and coincides with a bottom-hole temperature of approximate $300^{\circ} \mathrm{F}$.

\section{F. Investigation of Depth Effect on Permeability}

Petroleum engineers are aware that permeability generally decreases with depth, due to the increasing weight of overburden. It has been suggested that the permeability of geopressured formations may be higher than in equivalent normally compacted zones, because the overburden pressure should initially be somewhat offset by the load-bearing effect of the abnormally pressured water. An attempt was made to evaluate this effect, by examining the permeability of a large number of gas wells producing from a variety of reservoirs at all depths, both normally and abnormally pressured. The results of this study are summarized in Figure 23, plot of effective permeability versus depth for more than 100 gas wells throughout the study region. This plot fails to disclose any obvious trend toward either reduced or. increased permeability caused by penetrating the geopressured zone. The overwhelming effect displayed is that of reduced permeability with depth, regardless of formation fluid pressure. The trend shown in this figure is particularly disappointing, since in no case are wells with permeability as great as $10 \mathrm{md}$ shown to be coincident with depths at which temperatures as high as $300^{\circ} \mathrm{F}$ occur. The overwhelming number of deep south Texas reservoirs exhibit effective permeability values of $1.0 \mathrm{md}$ or less.

Results of studies in two fields, one in the south and one in the north of the study region, are shown in Figures 24 and 25. In these figures, permeability of a number of producing horizons in the same fields are plotted versus depth. In Figure 24, wells in the McAllen-Pharr field in Hidalgo County are summarized, and in Figure 25 results of investigation of the Ann-Mag field in northern Brooks County are shown. In both cases, the reduction in permeability with depth appears to amount to roughly one order of magnitude for each $2000 \mathrm{ft}$ of increased depth, in the range from 6,000 to $14,000 \mathrm{ft}$.

\section{G. Significance of Permeability to Long-Term Water Well Performance}

Parmigiano (1973), in the only comprehensive study of geopressured water production known to the authors, has analyzed the aquifer size requirements for production of useful quantities of energy from Gulf Coast formations of this type. In order to investigate the effect of permeability on the performance of south Texas aquifers, calculations of transient and steady-state behavior of such reservoirs under various permeability conditions were performed during this program.

When water is first produced from a subsurface reservoir, there is a transient period during which the well can produce at very high rates of flow. If the well is flowed at a constant maximum rate, the pressure will decline exponentially for a relatively short period of time, after which it will continue to decline linearly until the reservoir is depleted. A well in a reservoir with a permeability of $100 \mathrm{md}$ capable of producing $100,000 \mathrm{bbl}$ water/day for 20 years, would be capable of flowing at a rate in excess of 1 million bbl water/day after one day of production (if casing and tubing were sufficiently 


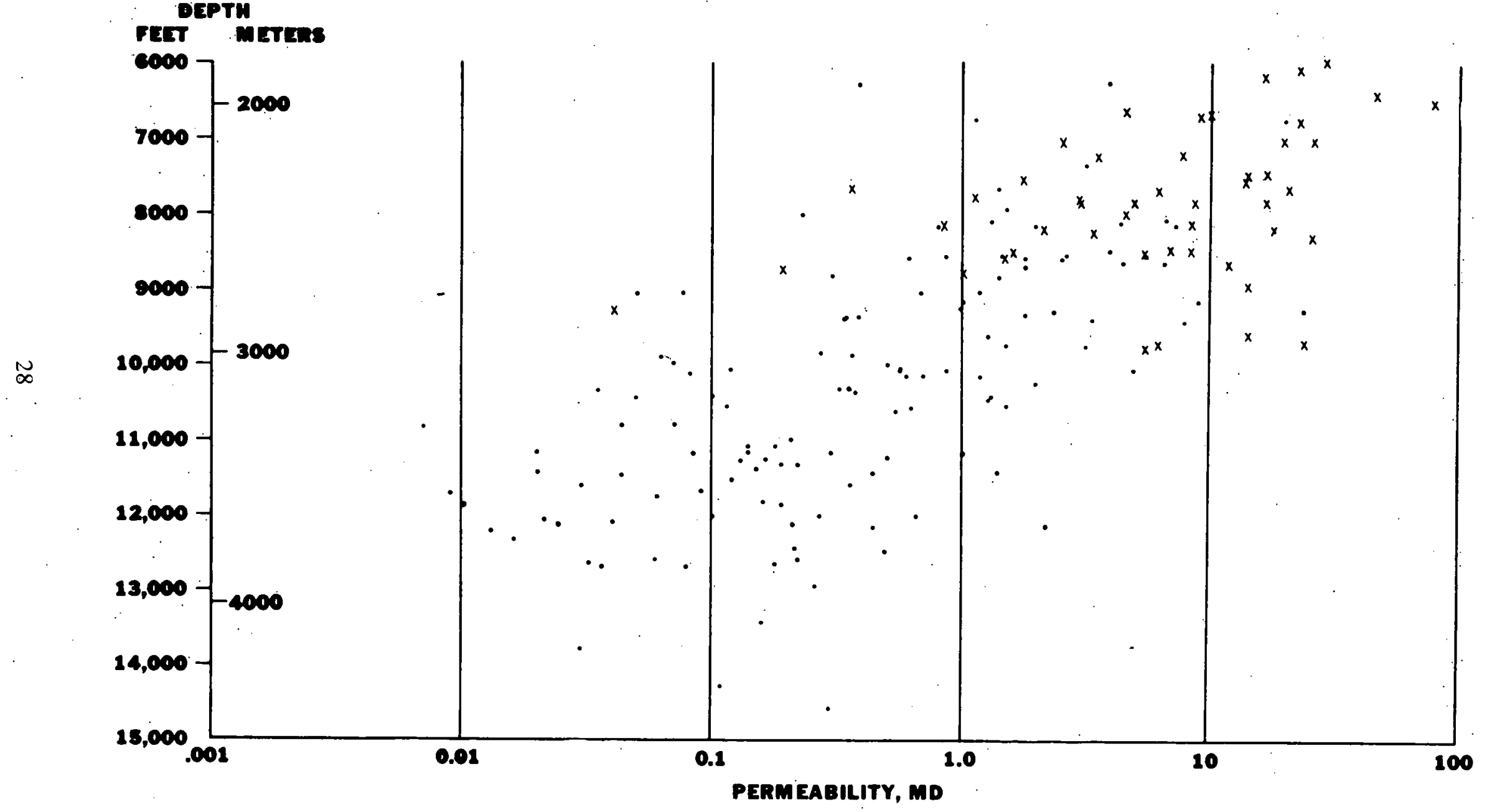

$X$ normally pressured wells • geopressured wells

I:IGUIRI: 23. 1:1FTICTIVI: PERMEABILITY VS. DEPTH FOR A LARGE NUMBER OF GAS WELLS IN IIIIAALCO. BROOKS. CAMIERON ANI) KLNNEDY COUNTIES IN SOUTH TEXAS 


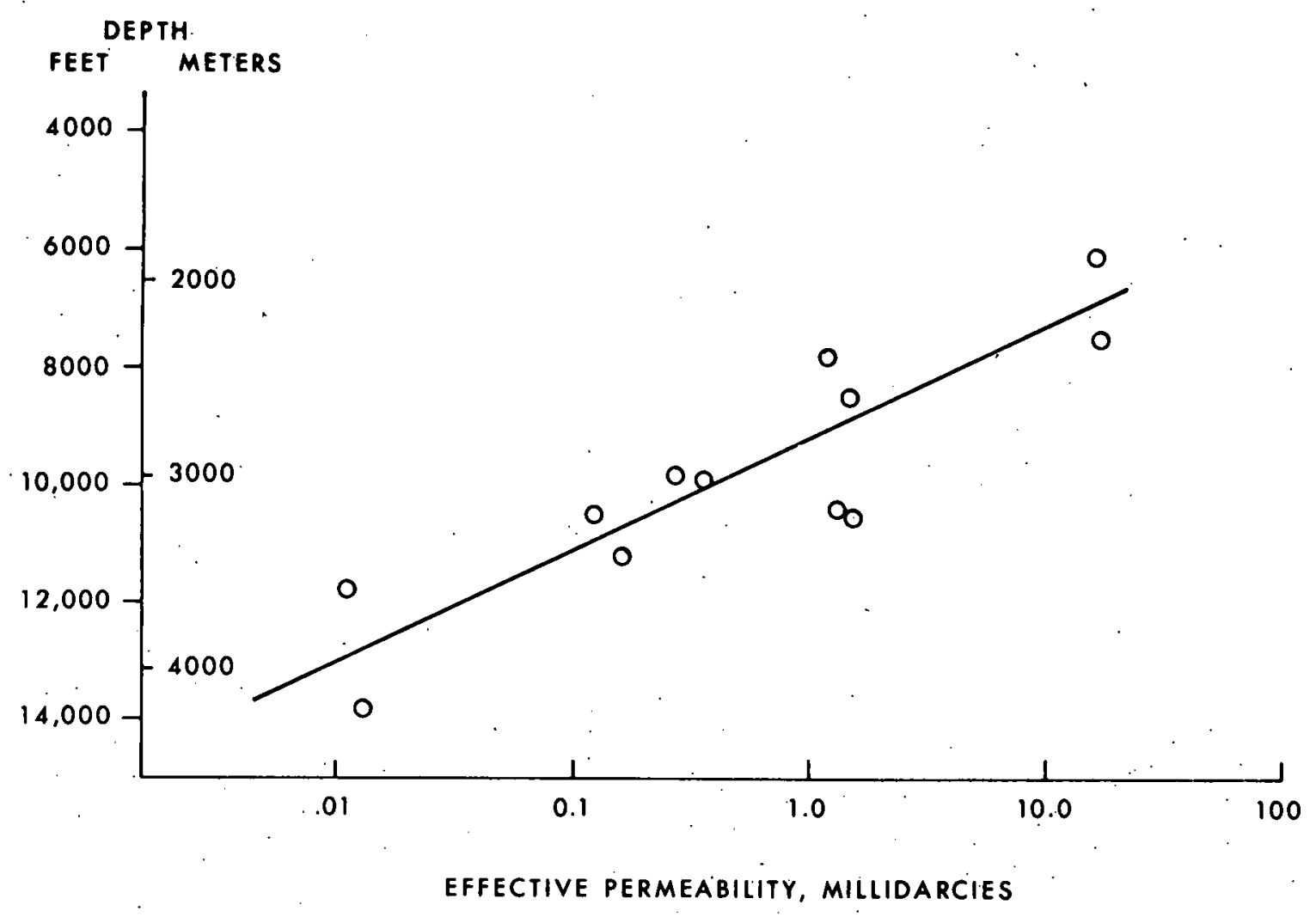

FIGURI: 24: VARIATION OF EFIECTIVE PERMEÄBILITYY WITH DEPTH, MCALLEN-PHARR AREA

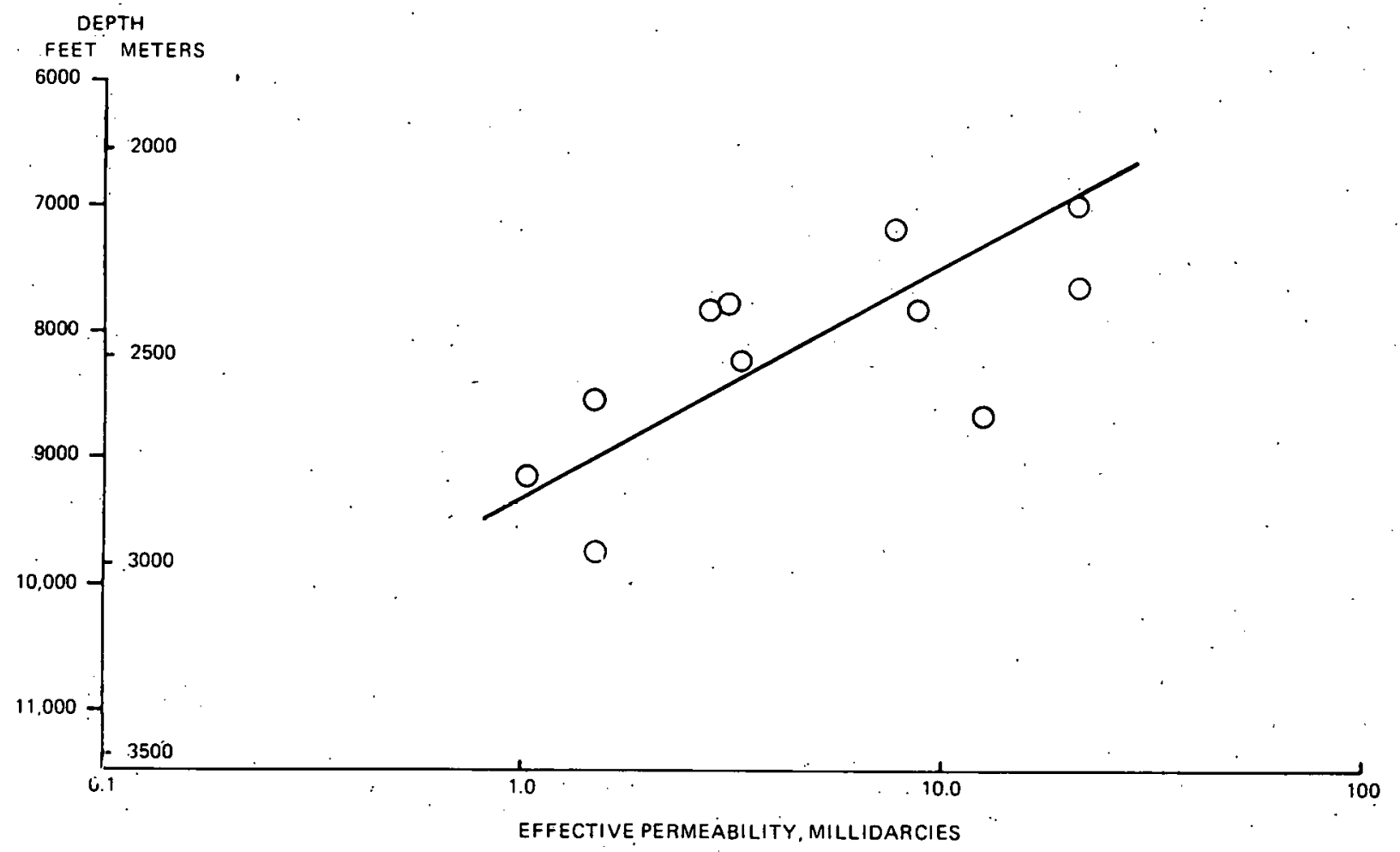

FIGURE 25. VARIATION OF PERMEABILITY WITH DEPTH, ANN-MAG FIELD, NORTHERN BROOKS COUNTY 
large). After 100 days, the open-flow potential would still be nearly $800,000 \mathrm{bbl}$ of water/day. Open-flow tests of the producing capability of a well early in its life greatly exceed rates that the well can sustain for a long period, e.g. 20 years.

An examination of data from gas fields in south Texas indicates that the permeability of geopressured reservoirs there is much lower than $100 \mathrm{md}$, seldom is as high as $10 \mathrm{md}$, and frequently is less than $1.0 \mathrm{md}$. Calculations were made to determine how long a well would produce at a rate of $100,000 \mathrm{bbl}$ water/day if the permeability were less than $100 \mathrm{md}$. The results are shown in Figure 26.

Formation parameters assumed in these calculations are as follows:

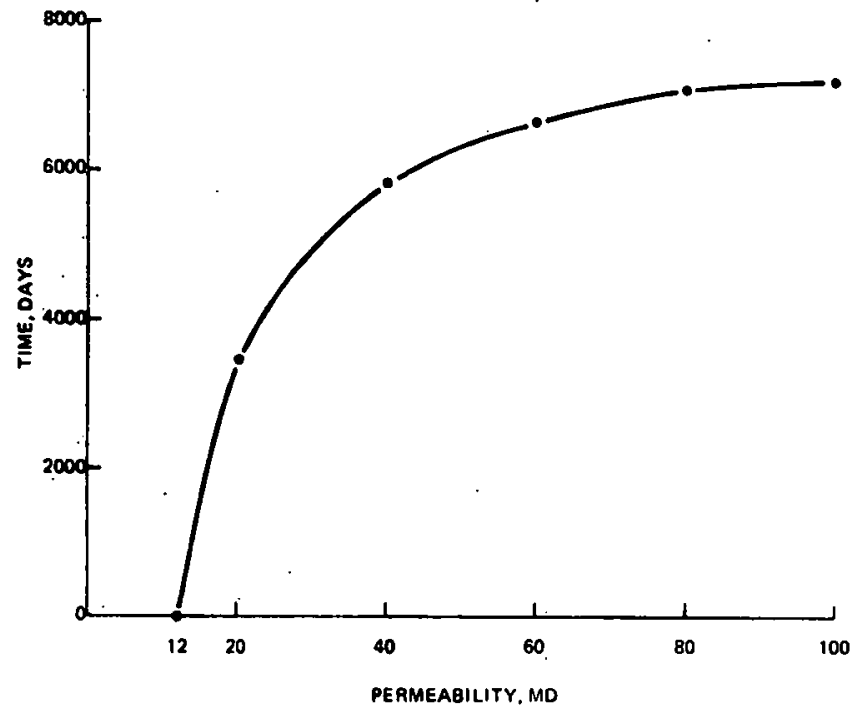

FIGURE 26. FLOWING TIMI:, DAYS, I:OR WHICH A WLLL CAN MAINTAIN A FLOWING; RATL OF 100,000 BBL WATER PER DAY, VS RESERVOIR PERMEABILITY
Formation thickness

Porosity Initial Pressure Hydrostatic Pressure Pressure drop (9-7/8" pipe)

Radius of well

Radius of reservoir Compressibility Viscosity of water Permeability

$$
h=500 \mathrm{ft}
$$$$
\phi=12 \%
$$$$
P_{\dot{e}}=10,000 \mathrm{psi}
$$$$
P_{h y}=5200 \mathrm{psi}
$$$$
P_{f}=280 . \mathrm{psi}
$$$$
r_{w}=0.401 \mathrm{ft}
$$$$
r_{e}=9326 \mathrm{ft}
$$$$
C_{e} \cdot=6.23 \times 10^{-5}
$$$$
\mu_{w}=0.2 \mathrm{cp}
$$$$
k=\text { variable }
$$

Calculations indicate that in such a reservoir if the permeability were less than $12 \mathrm{md}$, the well would not flow $100,000 \mathrm{bbl}$ water/day. The length of time a well would flow at a rate of $100,000 \mathrm{bbl}$ water/day increases rapidly as the permeability of the reservoir increases as shown in the figure. If the permeability of the reservoir were $100 \mathrm{md}$, the well would flow for 20 years.

If the reservoir permeability were as little as $1 \mathrm{md}$, the well would flow approximately $9,000 \mathrm{bbl}$ water/day for 20 years. These calculations are shown in Appendix C.

\section{H. Water Salinity}

Reliable data on salinity of connate water from producing horizons in the study region were obtained where possible, and a regional overview of water quality from these data is summarized on the map in Figure 27. The least saline water occurring over a sizable area was found along the Weslaco fault in lower Hidalgo County. Here "fresh" water sands (water salinity of 4000-6000 ppm $\mathrm{C} 1$ ) occur generally as massive sand units in the basal Frio and upper Vicksburg formations. This is in contrast to local, isolated fresh-water sands that are sometimes identified on well logs in geopressurized zones in many places in the study area. Fresh water is also common, although not general, in Live Oak County.

\section{Reports of Well Tests}

The results of several drill stem and production tests of unsuccessful gas well completions in the geopressured zones have been located. These give considerable insight into the problems of developing high-volume water wells in these reservoirs. 

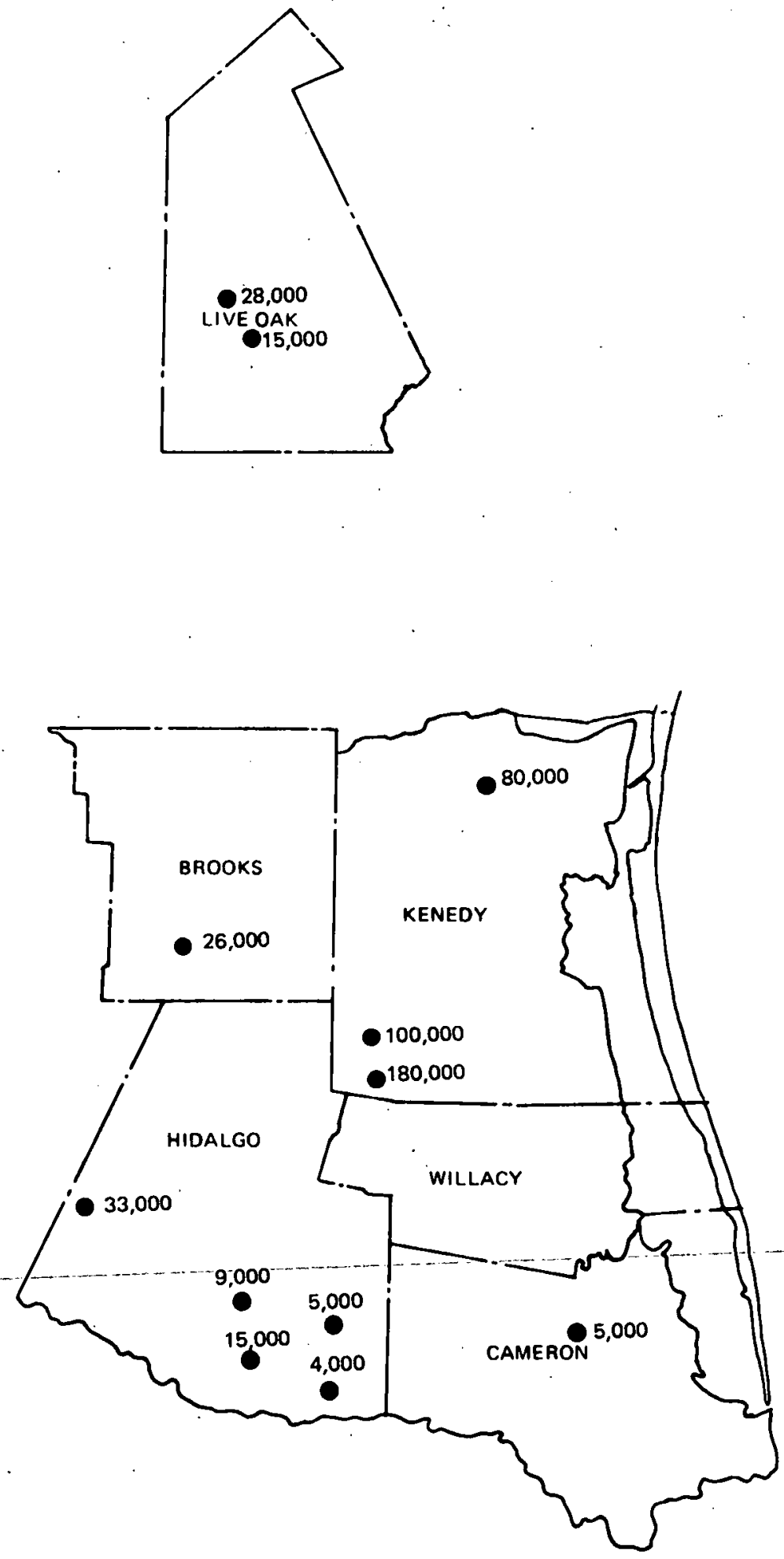

IIICURE 27. CONNATE WATER SALINITY, PPM C1, REPRESENTATIVE GEOPRESSURED PRODUCING RESERVOIRS IN SOUTH TEXAS 


\section{Donna Area, Hidalgo County}

The most recent of these tests was in the Mercedes-Donna area, near the Donna fault (Lone Star Prod. Co. No. 1 Denzer). The well is typical of the area east of the Donna fault near the Cameron County line, exhibiting low salinity, high-resistivity Frio sands. We believe this well was completed in a water sand, and represents an unwitting test of a geopressured water zone. The $\log$ is reproduced in Figure 28.

After several unsuccessful deep completion attempts, the well was perforated (selectively) from 9371-9268, acidized and given a nitrogen pressure treatment. The well flowed gas, nitrogen, and formation water. On a 20/64-inch production choke, the well tested an absolute open-flow potential of $280 \mathrm{mcf}$ gas per day, plus 450 barrels of water $(5400 \mathrm{ppm} / \mathrm{Cl})$. This declined to 120 mcf plus 140 barrels of water, and the completion was aborted with a plug. Other perforations at depths from 8994 to 8818 produced similar results and the well was abandoned.

This completion attempt opened a total of $42 \mathrm{ft}$ of perforations in the geopressured zonc from which the potential test was made. The 450 barrels of water/day with substantial gas is probably typical of the test results one can expect from water sands in this area. Likewise, the rapid decline can be expected, the probable result of gas released from the water due to the pressure drop in the formation. The relative permeability is such that released gas quickly dominates the flow, blocking further water flow as a result. This reduces the rate at which gas can be released, and the rate of flow of both steadily declines. We believe this sort of performance can be expected in any flow test in the consolidated formations of this region, unless measures are taken to drastically restrict flow rate.

\section{Santa Maria Area}

A somewhat deeper test in the same general vicinity is reported by Shell in the No. 1 W.H. Drawe in the Santa Maria area, south of the Weslaco field. In this completion test, perforations selectively opened a total of $10 \mathrm{ft}$ between 11,594 and 11,660. The report only indicates that the well "flowed small amount gas and water through $3 / 8$ inch choke," but the flowing tubing pressure dropped from 5000 to $20 \mathrm{lb}$ during the test, indicating the same general condition as in the first test reported above.

\section{Mercedes Area}

In a third well (J.M. Huber Corporation No. 1 A.M. Miller), similar test results were obtained about 1 mile southwest of the Mercedes field. The $\log$ of this well is shown in Figure 29. A total of $27 \mathrm{ft}$ of perforations was opened between 12,873 and 13,083, and the well completed for a test potential of $450 \mathrm{mcf} /$ day plus 350 barrels of water/day. Tubing pressure dropped slowly from 4317 psi to $39 \mathrm{psi}$. This well was also abandoned.

\section{Edinburg Area}

A fourth dry hole is of interest because it apparently tested water sands in an area off the south flank of the south Edinburg field in one of the favorable geopressured areas of Hidalgo County, from the standpoint of geopressured sand development. This well (Standard of Texas, No. 1 L.E. German Unit) is located 4 miles southeast of the city of Edinburg. The tests reported open holc drillstem tests of the Reichert sand, a deep Vicksburg sand in the area, and production tests in the Marks \& Bond Sands. The deeper test, a 4.5 minute open-hole drill stem test, was run below 5-in. 


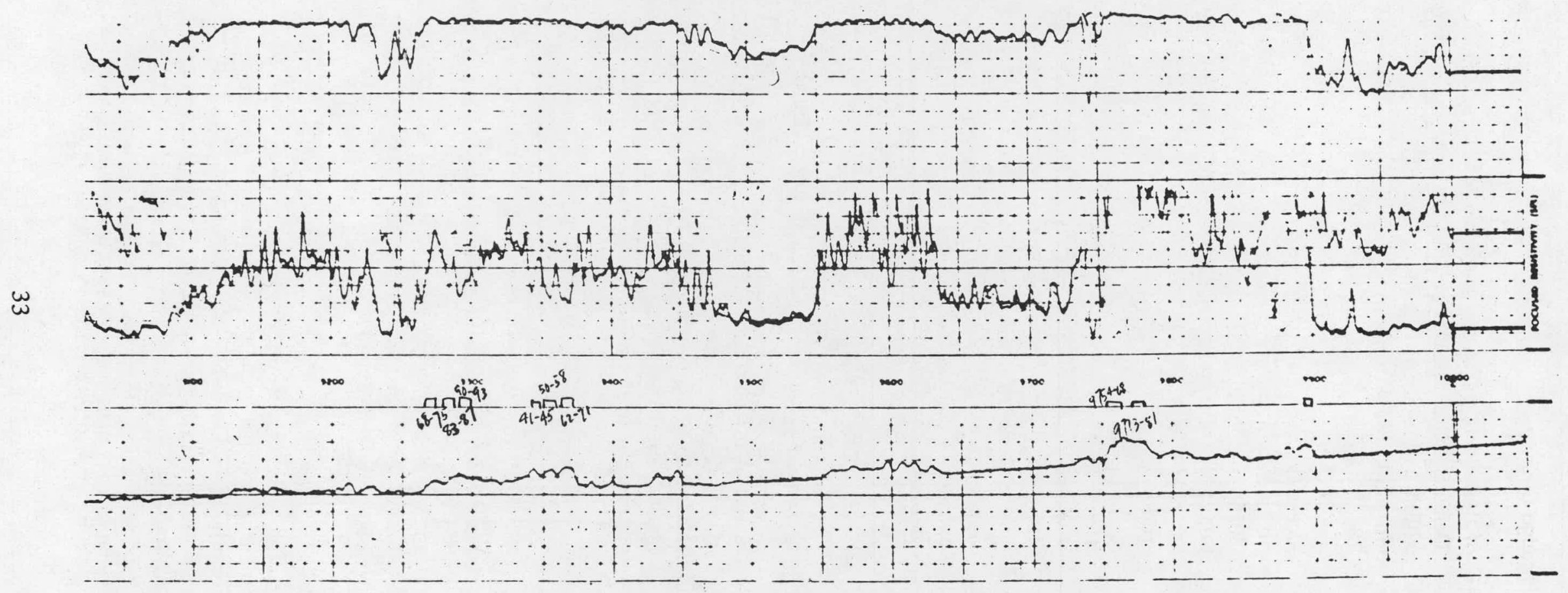

FIGURE 28. SOUTH HIDALGO COUNTY TEST WELL. Highly resistive, fresh water sands are typical of deep Frio in this area. (Lone Star No. 1 Denzer, Donna Area. See text.) 


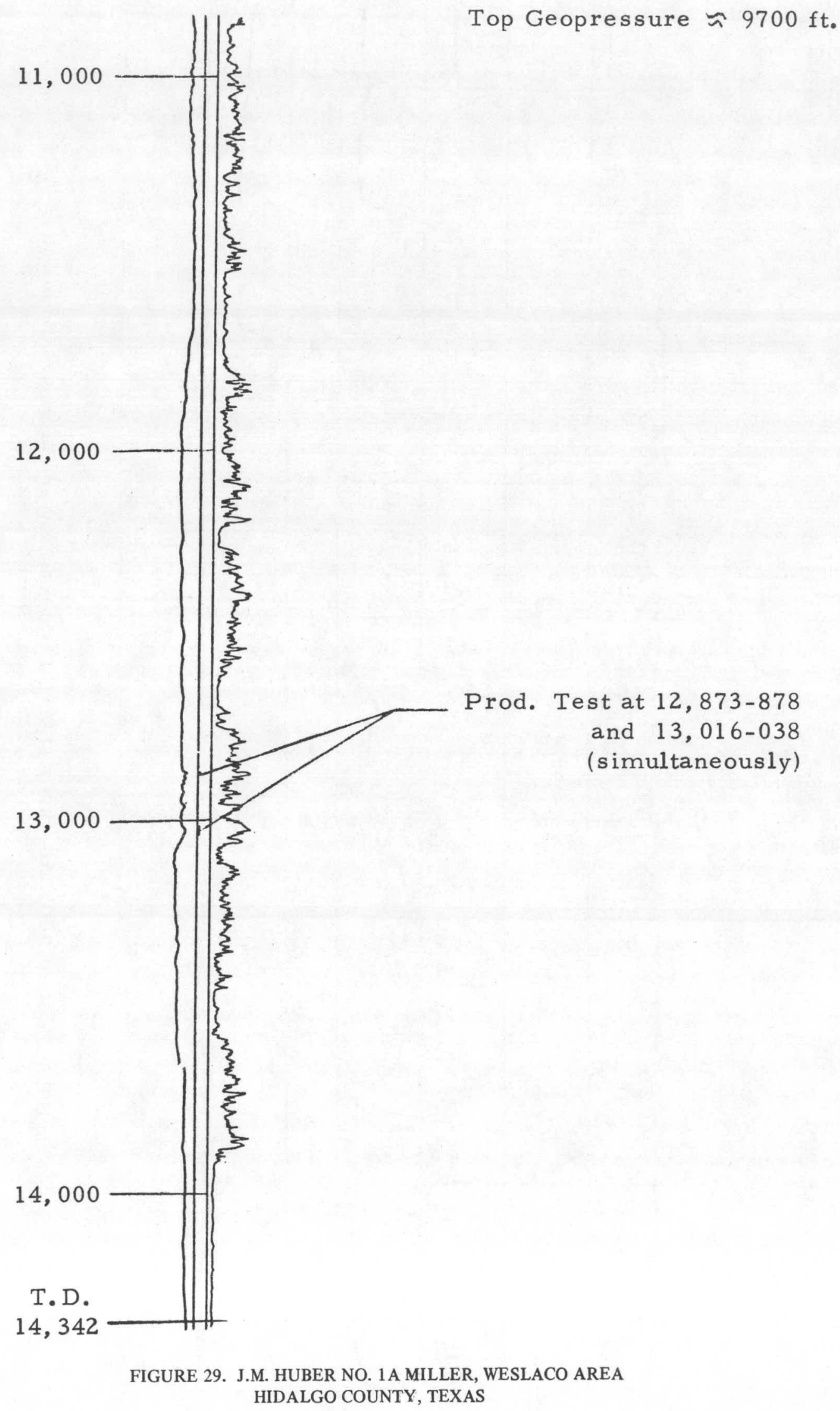


casing from 13,206 to $13,665 \mathrm{ft}$, through an 8/64-inch choke with full stage water cushion. The test recorded shut-in pressure of 11,275 to 11,445 psi, flowing pressure of 6926 to $7553 \mathrm{psi}$, and recovered $5400 \mathrm{ft}$ of gas-cut mud. A plug was set at $12,000 \mathrm{ft}$ and a number of production tests attempted through perforations in the Bond and Marks series from 11,598 to 10,977. Each of these tests produced a small amount of water and some gas. Water salinity of recovered water varied from 14,000 ppm to $4,500 \mathrm{ppm}$ in the various sands of these zones.

The normally productive sands are wet in this well. The relative permeability is such that when the sands are water saturated, little or no flow is obtained. The gas is probably released from water solution. This behavior seems to be typical of the Edinburg field. Wells below the gas-water contact will not flow, or will flow only a small amount of water and gas.

\section{Southern Brooks County, Encinitas Area}

Test results of Vicksburg geopressured sands in southwestern Brooks County have been reported by Coastal States Producing Company, in the No. 1 DeLuna in the East Encinitas field, 8 miles south of the town of Rachal.

A section of the well $\log$ of this well is reproduced in Figure 30. It is a typical Vicksburg zone of a type represented by fields such as Kelsey, McAllen Ranch, and Jeffress in Hidalgo County. The well was bottomed in the Vicksburg at $11,377 \mathrm{ft}$ and casing set to bottom. Top of geopressure (not shown in the figure) is between 8700 and $8800 \mathrm{ft}$.

Production testing in this well began in the deeper zone, through perforations from 10,895 to 11,134 . This zone failed to produce fluid, even after bailing dry. The sand is undoubtedly wet, but with effective permeability essentially zero, in spite of the fact that it is an example of excellent deep Vicksburg sand development. These perforations were squeezed.

The well was then perforated in the next higher zone from 10,447 to $10,749 \mathrm{ft}$. This 300-ft interval flowed a small amount of water in initial tests. After bailing the perforations, the well flowed a small amount of gas and condensate with a flowing tubing pressure of $850 \mathrm{lb}$. The zone was reperforated from 10,555 to $10,749 \mathrm{ft}$ and given a fracture treatment. The well immediately sanded-up (frac sand). The well was cleaned and swabbed in after which it flowed gas, some water and continued to flow frac sand. The completion was unsuccessful, and the well was squeezed.

Final perforations were made in the upper zone from 9,766 to $79 \mathrm{ft}$. The well flowed gas, condensate and water on test, with a tubing pressure of $1,275 \mathrm{lb}$ (flowing). The well was squeezed and reperforated from 9,766 to $73 \mathrm{ft}$, and successfully completed, with AOF potential of 11 million CFGPD and a bottom hole shut-in pressure of $6365 \mathrm{psi}$. This zone has a calculated $\mathrm{kh}$, from buildup-drawdown tests, of $22.5 \mathrm{md}$ feet ( $3.2 \mathrm{md}$ ).

The tests of the lower zones in this well are very discouraging; although sand development is good, pressure gradient is high, and the equilibrium temperature close to $300^{\circ} \mathrm{F}$ at a relatively shallow depth, the zone evidently will not produce water.

Other wells in the Encinitas field have produced at depths below 10,000 ft, but only gas, and none with permeability as high as the 9700-ft zone in the DeLuna well. The deepest production recorded in the field, the Texaco No. $36 \mathrm{McGill}$ Bros. was completed in a zone from 10,707 to $10,942 \mathrm{ft}$. The effective $k h$ of the entire $235-\mathrm{ft}$ zone was less than $1 \mathrm{md}-\mathrm{ft}$. 


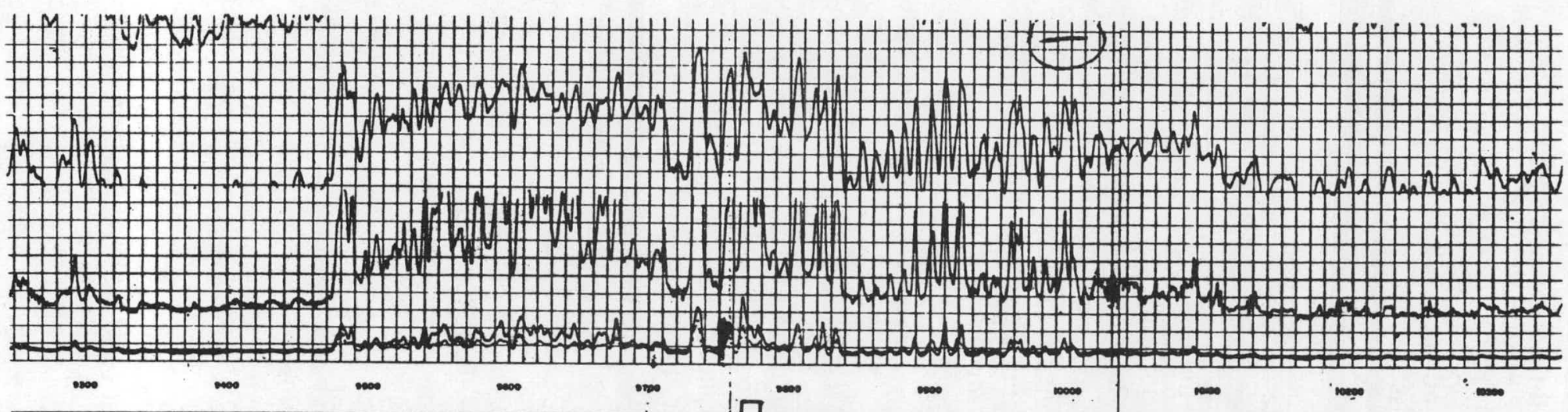

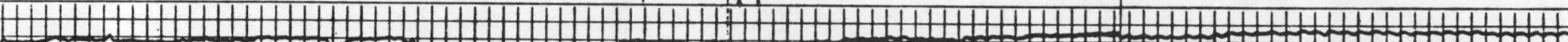

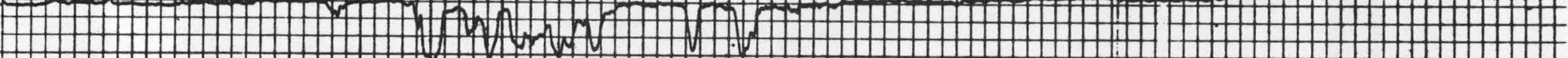
P

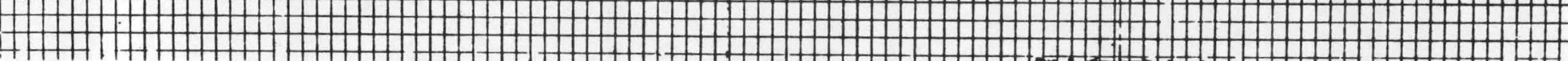

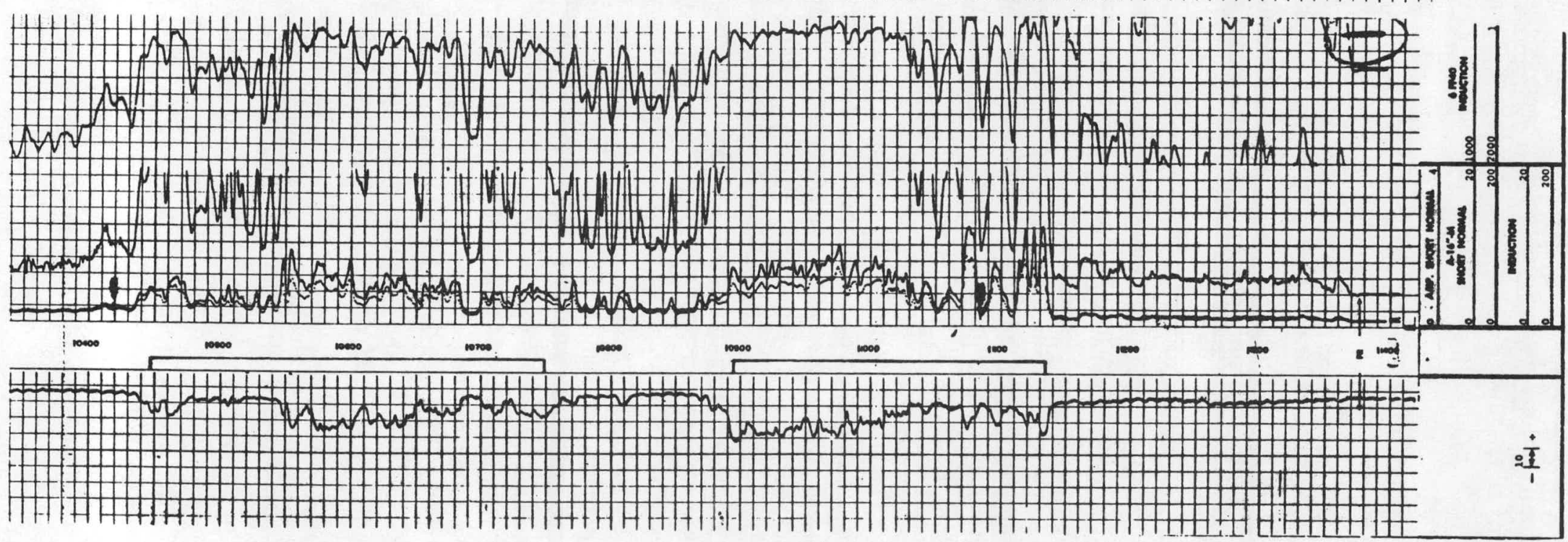

FIGURE 30. SOUTH BROOKS COUNTY WELL IN WHICH DEEP VICKSBURG PRODUCTION TESTS (in zones marked) WERE REPORTED. (Coastal States No. 1 DeLuna, see text) 


\section{Effect of Fracture Treatment}

Another well in the same field gives insight into the effect of hydraulically fracturing low permeability Vicksburg sands. A section of the $\log$ of this well, the Coastal States No. 1 Pettus, is shown in Figure 31. Abnormal pressures were encountered at approximately $8500 \mathrm{ft}$. Recorded bottom hole temperature at 10,908 was $236^{\circ} \mathrm{F}$. The well was completed in the zone from 10,213 to 10,422 , and on production test, tested $3.4 \times 10^{6}$ CFGPD. The well then received a frac treatment, following which it tested $4.7 \times 10^{6} \mathrm{CFGPD}$.

Calculated effective permeability after fracturing was $0.09 \mathrm{md}$, an improvement of a factor of 2. This is typical of successful fracture treatments in tight Gulf Coast formations at this depth. Flow rate increase equivalent to a two-fold permeability improvement is about the best that can be expected.

\section{Live Oak County, Tom Lyne Area}

An inadvertent test of a water-sand was located during the study of Live Oak County. Atlantic Refining Company originally completed the No. 8 T. J. Lyne in 1961. During completion tests, a lower Wilcox sand was perforated from 10,366 to $10,372 \mathrm{ft}$. The well flowed salt water and gas, and was allowed to clean itself into the pits and continue flowing. On a 1/4-in. choke, the well flowed salt water at the rate of $350 \mathrm{bbl} / \mathrm{day}$, with a bottom-hole flowing pressure of $7300 \mathrm{psi}$, and bottom-hole shut-in pressure of $7930 \mathrm{psi}$. Water salinity was $28,000 \mathrm{ppm} \mathrm{Cl}$. The well was eventually squeezed and recompleted at 10,194 to 10,206 ft. Within $1 \mathrm{yr}$, that zone had also watered out, and the well was plugged back and recompleted in a shallow, normally-pressured sand. Temperature at the $10,000-\mathrm{ft}$ depth is approximately $270^{\circ} \mathrm{F}$. 


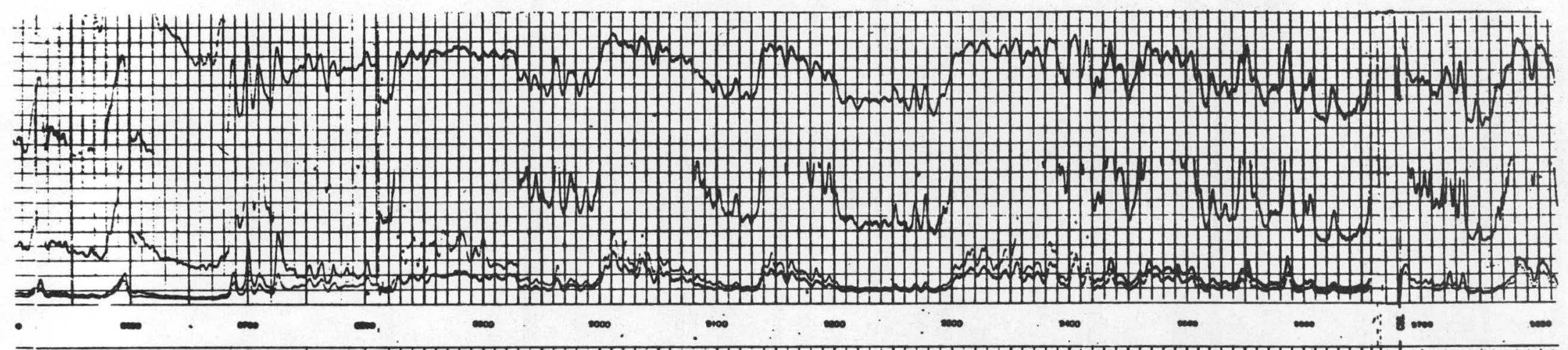

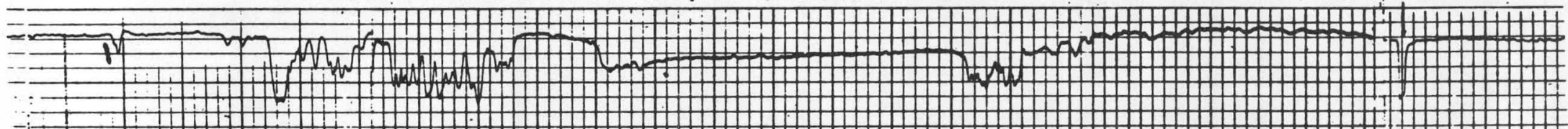

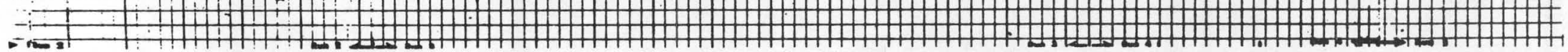

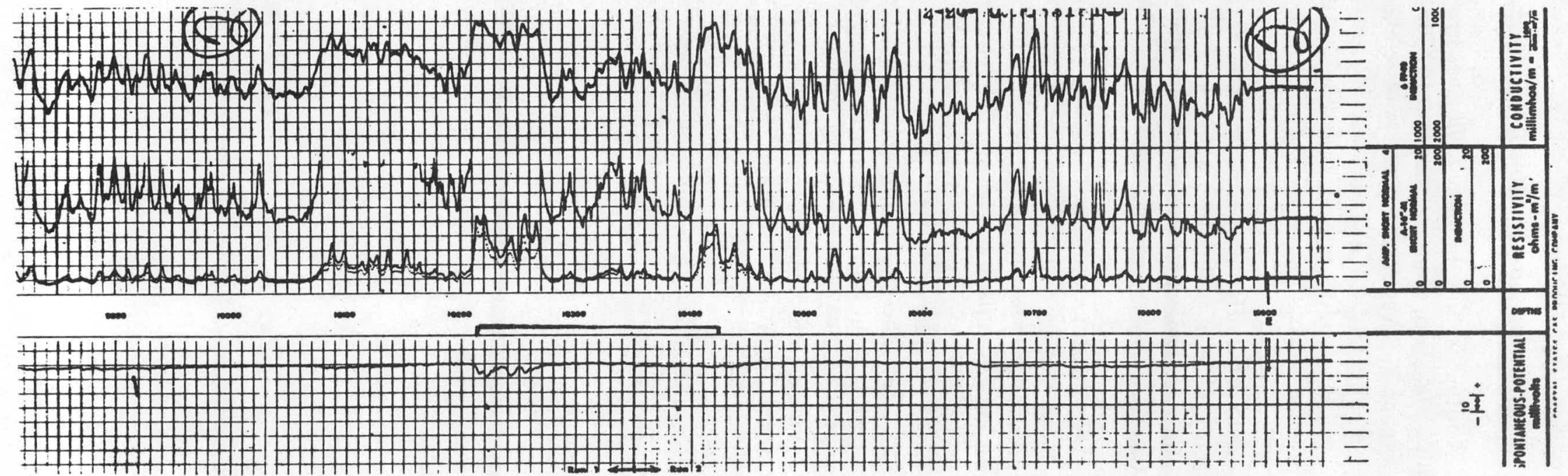
FIGURE 31. SOUTH BROOKS COUNTY VICKSBURG WELL IN WHICH FRAC TREATMENT IS SHOWN TO INCREASE EFFECTIVE PERMEABILITY ABOUT TWO-FOLD. (Coastal States No. 1 Pettus, sec text) 


\section{GEOLOGY AND ASSESSMENT OF PRODUCING AREAS}

On the basis of the reservoir evaluation and a geologic investigation of each field, assessment of the individual producing areas has been made and is summarized in the following paragraphs.

The question of fluid deliverability has been shown to be paramount in considering the south Texas geopressured formations as an energy source. In consideration of this question, the permeability-thickness product, or $\mathrm{kh}$, is the critical parameter in determining initial flow rates, while areal extent is mainly of importance in establishing reservoir life. Considerable effort has been spent in determining effective permeability values throughout the Study Region, and these have been shown to be low. The only compensating factor is formation thickness. The philosophy of this assessment has been to stress the importance of flow rate as compared to reservoir lifetime. If a reservoir will not produce fluid at an adequate rate, the size is immaterial. If adequate flow of fluid at reasonably high temperature can be achieved, the long-term performance can only be determined by extensive test programs. We have attempted to select those areas that represent the best potential for further evaluation, including testing.

\section{A. Brooks County-The Frio-Vicksburg Flexure}

The shallowest occurrence of geopressure in the study area was discovered along and to the east of the Frio-Vicksburg flexure which parallels the Gulf Coast just west of the Hidalgo County border, extending diagonally through central Brooks County and beyond. Geopressured reservoirs along this fault system are mainly in Vicksburg sediments of Oligocene Age, immediately underlying the Frio. The term "flexure" refers to the large folds on the downthrown side of the fault. Both the Frio and Vicksburg are greatly thickened to the east of the Frio-Vicksburg flexure.

During the geologic period preceding Vicksburg deposition (Jackson), the seas had transgressed. Vicksburg Seas, encroaching on a slowly subsiding coastal plain, brought huge quantities of argillaceous sediments inland, but to a point not so far advanced as in Jackson times. These sediments were the remnants of vast clastic deposits moved to the sea by the ancestral Rio Grande River. They accumulated as overlapping, irregularly lenticular sedimentary masses, reworked by longshore currents into an extensive system of barrier bars. The weight of these sediments is believed to have caused slumping of the Jackson continental slope, resulting in the Frio-Vicksburg flexure.

In many places along the Texas Gulf Coast, the Vicksburg formation consists primarily of marine shale, which can be traced laterally across upper south Texas into massive deltaic sandstone and shale in the Rio Grande Valley as described by Boyd and Dyer (1965). Nowhere is Vicksburg sand development better than in the Hidalgo-Brooks-Kenedy County region, and is responsible for much of the prolific petroleum production in this area.

Nine separate geopressured gas fields were identified in Brooks County. Without exception, the abnormally pressured production occurs in Basal Frio-Vicksburg or Vicksburg sands. In all but one (Viboras), the sand deposition is directly related to development and thickening along the FrioVicksburg flexure. In common with the Vicksburg formation throughout Texas, deposition is primarily shale; most of the sand buildup when it occurs is near the top of the section. On occasion, however, there are isolated sand units deep within the Vicksburg. These must be considered the principal geothermal prospects within Brooks County, since the upper units are at depths too shallow to offer temperatures of interest. 


\section{South Ann-Mag Field (No. 36 on Figure 2)}

Ann-Mag is an old, normally pressured oil fïeld on the Brooks-Kleberg county line. A relatively new field extension to the south, known as Ann-Mag South, is in Brooks County. Production is generally from lower Frio sands, with some production from abnormally pressured zones in the upper Vicksburg. Top of geopressure is generally coincident with the top of the Vicksburg at approximately $9000 \mathrm{ft}$. Control in the field to $10 ; 000 \mathrm{ft}$ is fair, but deeper control is lacking. Formation temperature at the deepest horizon penetrated, is approximately $250^{\circ} \mathrm{F}$ at $10,500 \mathrm{ft}$. Sand development in the Vicksburg below this depth is unknown. The effective permeability of the principal geopressured producing sand is less than 1 md at $9750 \mathrm{ft}$. Structurally, the upper.Vicksburg is largely undisturbed by faulting, as shown in the structure map in Figure 32. The lack of well control makes assessment of the high temperature zones impossible, but the low permeability in the producing sand is discouraging.

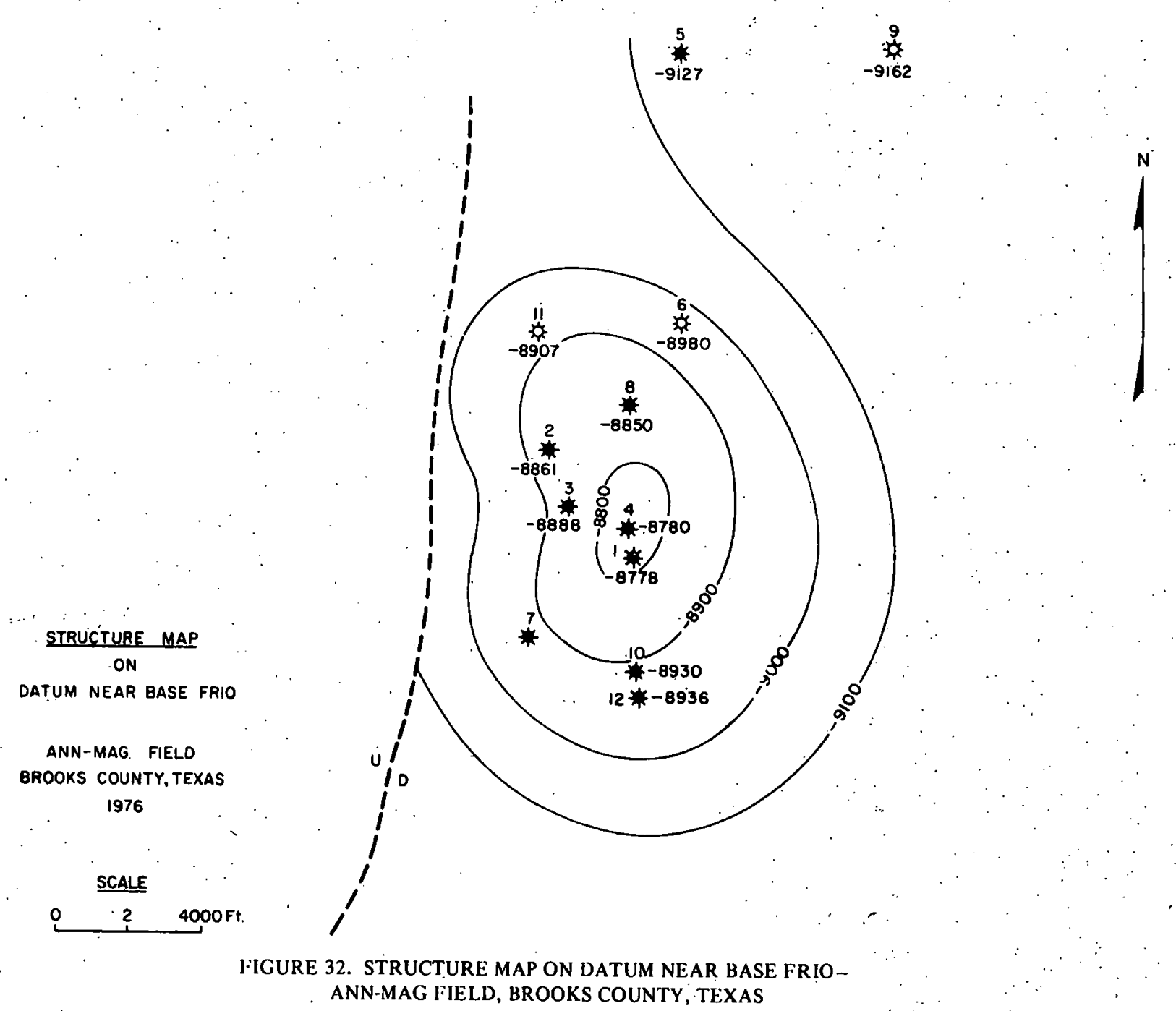

2. Viboras Field (No. 33 on Figure 2)

Viboras is a normally pressured gats and oil lield near thie Kenedy County border in east central Brooks County. The Fiedl, like Ann-Mag, nomally produces from lirio sands above the top of geopressure. The most favorable geothermal prospect in this area is in the southeast extension of 
Viboras field, across a large fault to the east. Frio-Vicksburg and Vicksburg sands are highly developed on the downthrown side (east) of this fault. Below the lower-Frio mapping datum in Figure 33 , Well No. 18 on the map (arrow, lower right) shows over $850 \mathrm{ft}$ of relatively clean, massive sands and clean sand stringers to about $-12,200 \mathrm{ft}$. The well has produced from a zone at 12,105 to 12,119 with an initial potential of $7.3 \mathrm{MMcf}$ gas per day. Calculated effective permeability in thits producing zone is approximately $0.5 \mathrm{md}$. The remainder of the well to total depth at $13,500 \mathrm{ft}$ encountered only shale. Temperatures in the well-developed sands range from approximately $220^{\circ}$ to $310^{\circ} \mathrm{F}$. Unfortunately, there is no other control on this section available. Wells Nos. 14 and 25 are not deep wells, but correlation is good on the mapping datum at the top of the zone: Based on this sketchy information, the zone immediately to the east of this fault can be considered a good prospect for the production of water at temperatures in the range of $250^{\circ} \mathrm{F}$.

One of thic significant questions about geothermal production from abnormally pressured zones is the ability of extensive vertical sections to produce fluid simultancously. If several hundred feet of section can be suceesslully produced, the generally low permeability may be somewhat compensated. S. E. Viboras is a good area in which to attempt to llow a long section of low permeability sand over a considerable depth interval.

The potentially productive section in this zone is shown in the log section in Figure 34 .

\section{Kelsey-Encinitas Area (Nos. 28 and 29 on Figure 2)}

Kelsey is a large, old oil field shared by Brooks, Starr, and Hidalgo Counties with major production occurring at shallow depths. A minor branch of the Frio-Vicksburg fault cuts the eastern edge of the field, providing some deeper sand buildup in the Vicksburg at depths below $8000 \mathrm{ft}$. The deep horizons of the Encinitas field are: on the same trend along the same fault. A structure map on a datum in the Textularia Warreni zone (Vicksburg) is shown in Figure 35. Geothermal possibilities on this trend are in a series of relatively clean Vicksburg sands from the top of geopressure at approximately 8,300 to about $10,000 \mathrm{ft}$. Available temperatures at these depths vary from about $200^{\circ}$ to $275^{\circ} \mathrm{F}$, but permeability is less than $1 \mathrm{md}$ in the single productive gas sand. Although geopressure occurs at a shallow depth and the temperature gradient is relatively high, overall sand development is only fair. With no favorable reservoir parameters uncovered, Kelsey and Encinitas fields cannot be considered to hold good geothermal potential.

\section{La Encantada Field}

This field is just to the northeast of Encinitas and there is some evidence that the principal aquifer is continuous. Sand development in the Vicksburg is only fair and permeability is low. The field produces from thin sand stringers that undoubtedly represent sand lensing. There is little to recommend this area other than a reasonably high-temperature gradient.

\section{Scott and Hopper Field (Map No. 31)}

This field lies along a main branch of the Frio-Vicksburg fault in central Brooks County, with excellent sand buildup immediately adjacent to the fault; although unfortunately the best sands are under normal pressure. The only known deep Vicksburg sand occurs to the east at 10,500 $\mathrm{ft}$. Wells have not explored this zone near the fault. There is inadequate control at depth to adequately assess the geothermal potential, but if the sand build-up continues to sufficient depth to thicken the 10,000 -ft sand, it could be an interesting prospect. The depth of the $300^{\circ} \mathrm{F}$ geothermal surface is at approximately $12,000 \mathrm{ft}$, and low priority can be given to deep exploration here. 


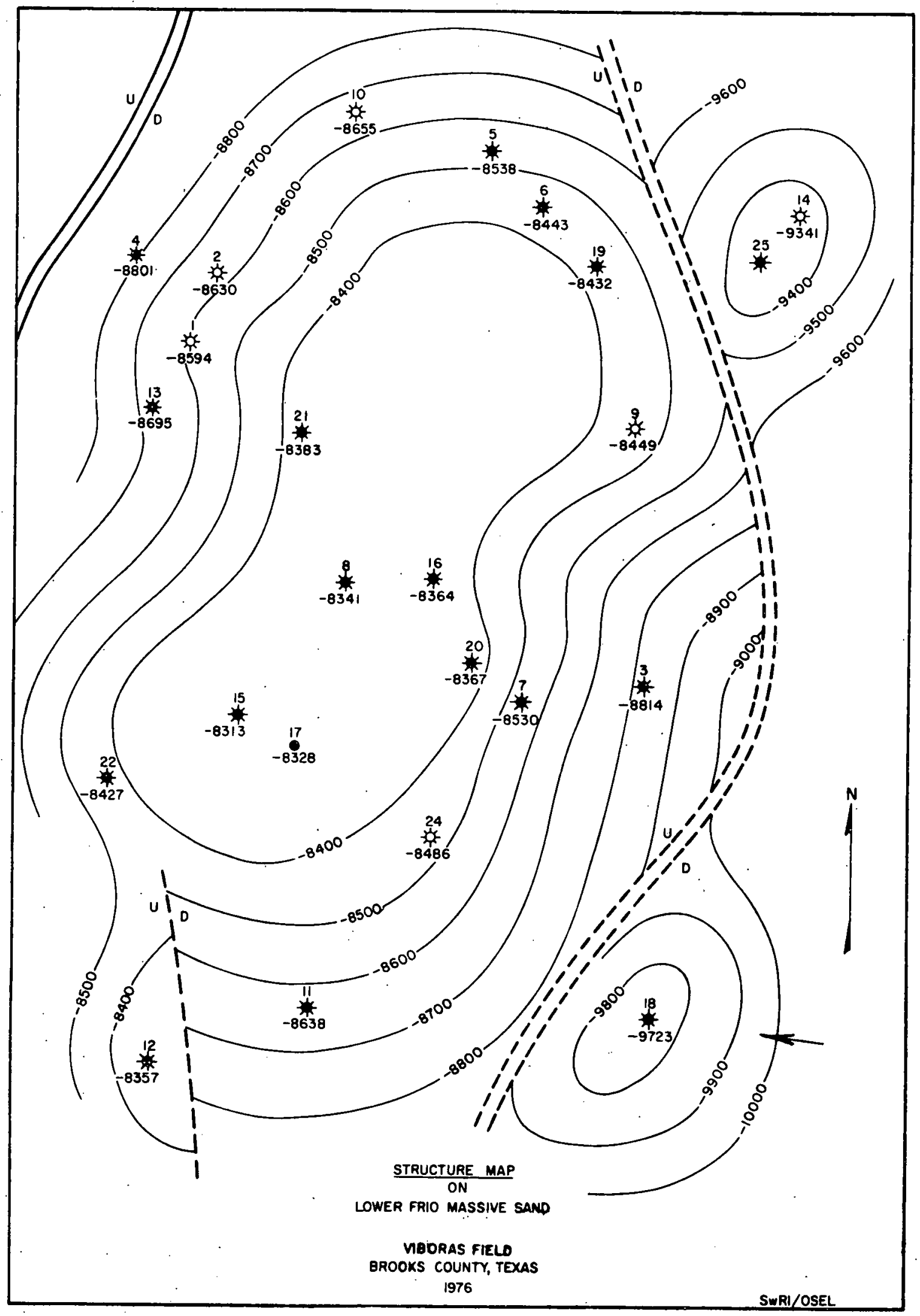

IIGURI: 33. SIRUCTURI: MAP ON IOWI:R I:RIO MASSIVI: SANI) VIBORAS IIII:LI), BROOKS (OOUN'Y, TI:XAS 


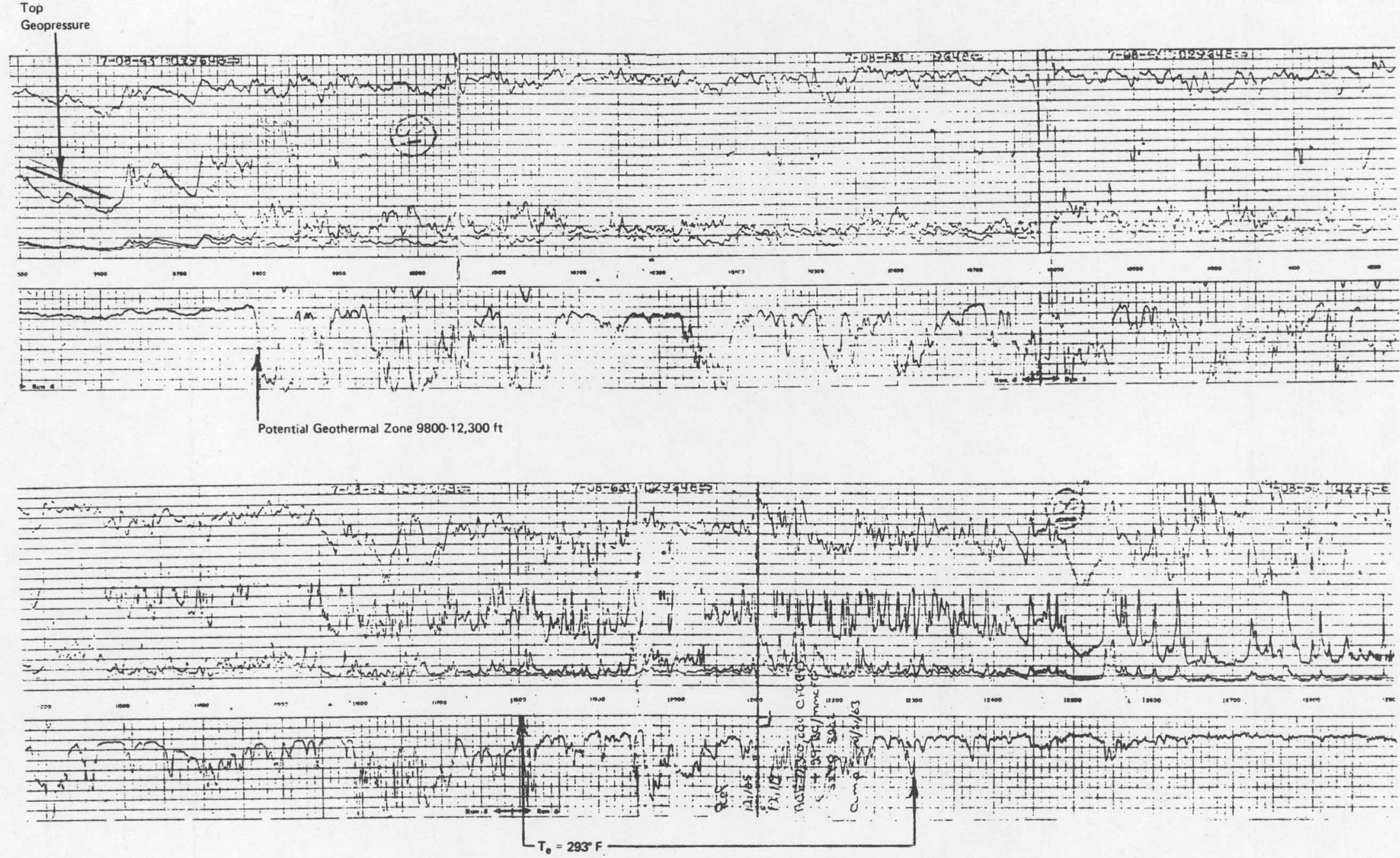

FIGURE 34. POTENTIAL GEOTHERMAL SANDS IN FRIO-VICKSBURG AND VICKSBURG SANDS,

S.E. VIBORAS FIELD, BROOKS COUNTY, TEXAS

Equilibrium Temperature at $11805 \mathrm{ft}=293^{\circ} \mathrm{F}$ (Humble $\# 37$ Kleberg) 


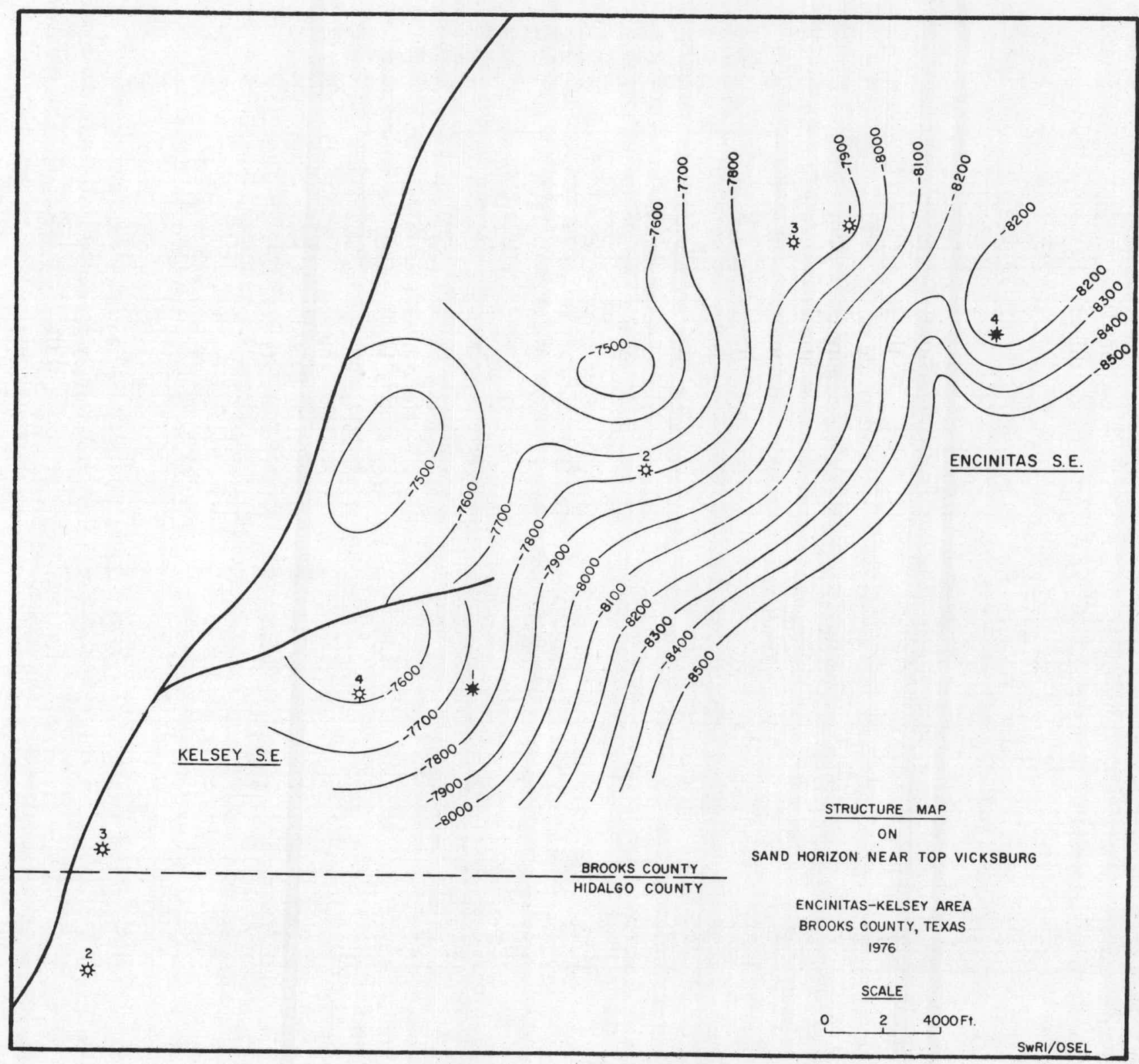

FIGURE 35. STRUCTURE MAP ON SAND HORIZON NI:AR TOP VICKSBURGENCINITAS-KELSEY AREA, BROOKS ('OUNTYY, TEXAS 


\section{Skipper-Cage Ranch-Alta Mesa Area (Map Nos. 32, 34, 35)}

Related structurally to Scott and Hopper and La Encantada fields and producing from generally shallow sands, these fields all have some production history from a common Vicksburg zone showing relatively good sand development at depths ranging from 9,400 to $10,500 \mathrm{ft}$. One of the best of these is shown on the log section in Figure 36 from the Skipper field. Although these sands are unusually clean for Vicksburg sands, permeability calculations from production tests indicate effective permeability of $1 \mathrm{md}$ or less. We do not consider this area to represent an attractive prospect.

\section{Summary of Brooks County Investigation}

All of the identified geopressured production in Brooks County lies to the east of the Frio-Vicksburg flexure and ranges from the base of the Frio through the Vicksburg formation. Several of the fields exhibit fair sand buildup on the downthrown side of the various faults in the region. The temperature gradient, particularly near the Frio-Vicksburg fault, is high but the depths to which exploration has reached are modest and there is little indication of potential production of water at temperatures as high as $300^{\circ} \mathrm{F}$. Faulting is somewhat less complex than in many parts of Hidalgo County, and the continuity of aquifers less disturbed by such faulting. However, the sands are often lenticular with small, single-well reservoirs the rule. We consider the best possibility to be in the southeast Viboras area near the Kenedy county line, where a test of methane production from water at $250^{\circ} \mathrm{F}$ or so could be accomplished at moderate depth from excellent Frio-Vicksburg sands. Testing of an extended vertical interval of low permeability needs to be attempted, and this is a promising place to do so.

\section{B. Kenedy County}

Sediments thicken basinward across the study region from west to east. Thus, Kenedy County is in an area of greatly thickened Frio and Vicksburg deposition, particularly near the coast. In most locations, the top of the geopressured zone is coincident, or nearly so, with the top of the Vicksburg. This point occurs at greater depth in Kenedy County than in Brooks County, but the temperature gradient in Kenedy County is lower. Production from Vicksburg sands is not so common in Kenedy as in Brooks County, although the deepest production $(15,000 \mathrm{ft})$ in the south Texas study region occurs in Vicksburg sand in E1 Paistle field, to the south of the Nueces county line. Temperatures as high as $300^{\circ} \mathrm{F}$ occur only in the Vicksburg and deeper sediments. A total of eight geopressured gas fields were located in the county.

\section{Candelaria Field}

Candelaria is in west central Kenedy County, to the east of a major extension of the McAllen fault. Most of its production history has been from normally pressured Frio sands, but two wells have produced gas from a geopressured sand that is probably in the Vicksburg. Many of the shallow Frio wells exhibit high permeability, but both geopressured producers show permeability less than $1 \mathrm{md}$.

The geopressured section in Candelaria includes the lower part of the Frio, and the Vicksburg formation. Both the Frio and Vicksburg sections contain sands of considerable thickness, individual units often measuring as much as 50 to $100 \mathrm{ft}$. However, correlations between the two Candelaria geopressured producing wells and dry holes in the area are extremely tenuous in the geopressured zone, suggesting sand lensing. Continuity of these sands over a broad areal extent, such as 

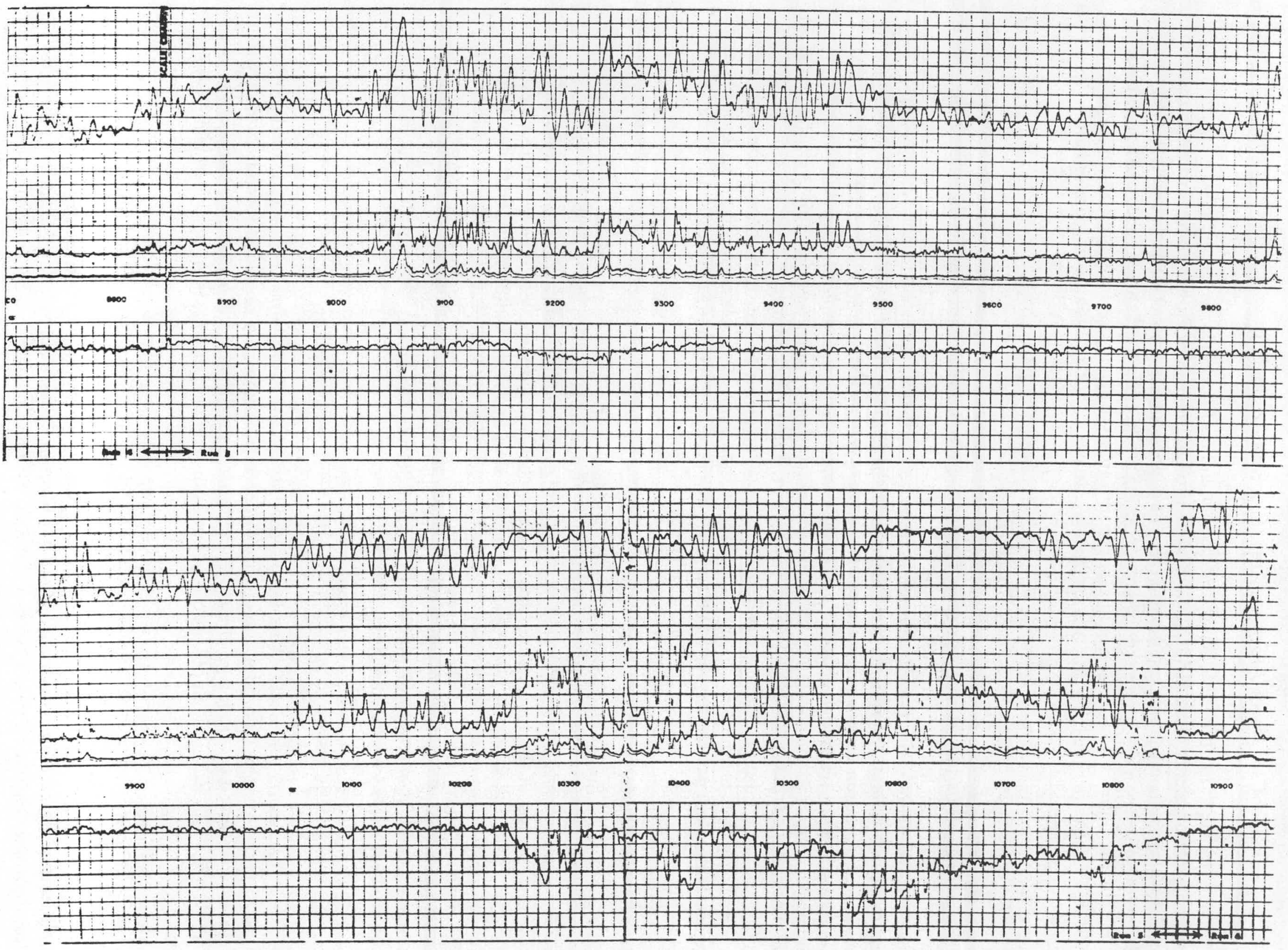

FIGURE 36. DEEP VICKSBURG SAND DEVELOPMENT TYPICAL OF CENTRAL BROOKS COUNTY, TEXAS

Approximately $250 \mathrm{ft}$ of Clean Sand between 10,250 and 10,800 ft. (Humble \#11 Skipper, Skipper Field) 
would be favorable for the containment and potential extraction of large quantities of water. appears unlikely.

Structure maps constructed on the top of the 8500 -lit sand unit in the lirio and another on the probable top of the Vicksburg appear as Figures 37 and 38 . Firom the available control, faults within the field are few in number, and small in displacement. The large fault displayed on the western side of the field was not encountered in the wells studied, but was projected from the work of others. The down-to-the-coast fault to the southeast of the field was only mildly defined by the Humble C. M. Armstrong No. 20 and No. 22 (designated as wells No. 3 and No. 7 in Figures 37 and 38). No evidence was found to indicate that prominent cross-faults isolate this area to the northeast or the southwest. Individual sand units in the Vicksburg are not readily correlatable from the Candelaria area to Mifflin, El Paistle, or Sarita fields to the northeast, but the good sand buildup in Candelaria thickens in that direction.

Numerous well-developed Vicksburg sands to depths as great as 17,000 ft have been logged, and in the absence of test information, production from zones of this type cannot be ruled out. Eventual testing of such deep sands in Candelaria, and to the east and northeast of Candelaria, may be warranted.

On the negative side, however, is the unlavorable reservoir information from shallower gas-producing sands, with Candelaria geopressured wells exhibiting very low (less than $1 \mathrm{md}$ ) permeability at depths of only 10,000 to 12,000 lt. The temperature gradient is low with the $300^{\circ} \mathrm{F}$ geotherm at approximately $13,000 \mathrm{ft}$, and the sands are probably lenticular. For these reasons, Candelaria rates only "fair" as a geothermal prospect.

\section{Rita Southeast}

The southeast extension of the shallow Rita field, immediately to the northwest of Candelaria, is apparently separated from Candelaria by stratigraphy. Correlation to Candelaria field is difficult, indicating the lenticular nature of the individual sand units. Overall Vicksburg sand development, however, remains good, but the limited deep control in the field prevents any serious assessment. The permeability in the producing sand at $12,800 \mathrm{ft}$ is low. We consider, from a geothermal standpoint, that this field is in the same trend as Candelaria and any lack of continuity of the aquifers is due to sand lensing. For geothermal purposes, this field can be grouped with Candelaria El Paistle, Sarita East, and Baffin Bay.

\section{El Paistle, Sarita East, and Baffin Bay}

These three deep fields in north central Kenedy County continue the trend toward thick. well-developed Vicksburg sands that extends northward from the Candelaria field. The deepest recorded production is in El Paistle field where the Humble No. 7 Kenedy was completed in a thick zone from 15,057 to $16,805 \mathrm{ft}$ with an initial potential of 2.4 MMcf gas per day. Effective permeability of this long interval is extremely low and discourages any prospects of deeper production. There are a number of well-developed sands at shallower depths in all three of these fields, with the best sands apparently occurring in Sarita. Production in Sarita has been from zones as deep as $14,500 \mathrm{ft}$. A type log from E. Sarita is shown in Figure 39.

The top of the geopressured zone in El Paistle is at approximately $11,200 \mathrm{ft}$ in the Vicksburg. Well-developed sands occur in intervals from 12,400 to 13,400 and from 14,200 to 


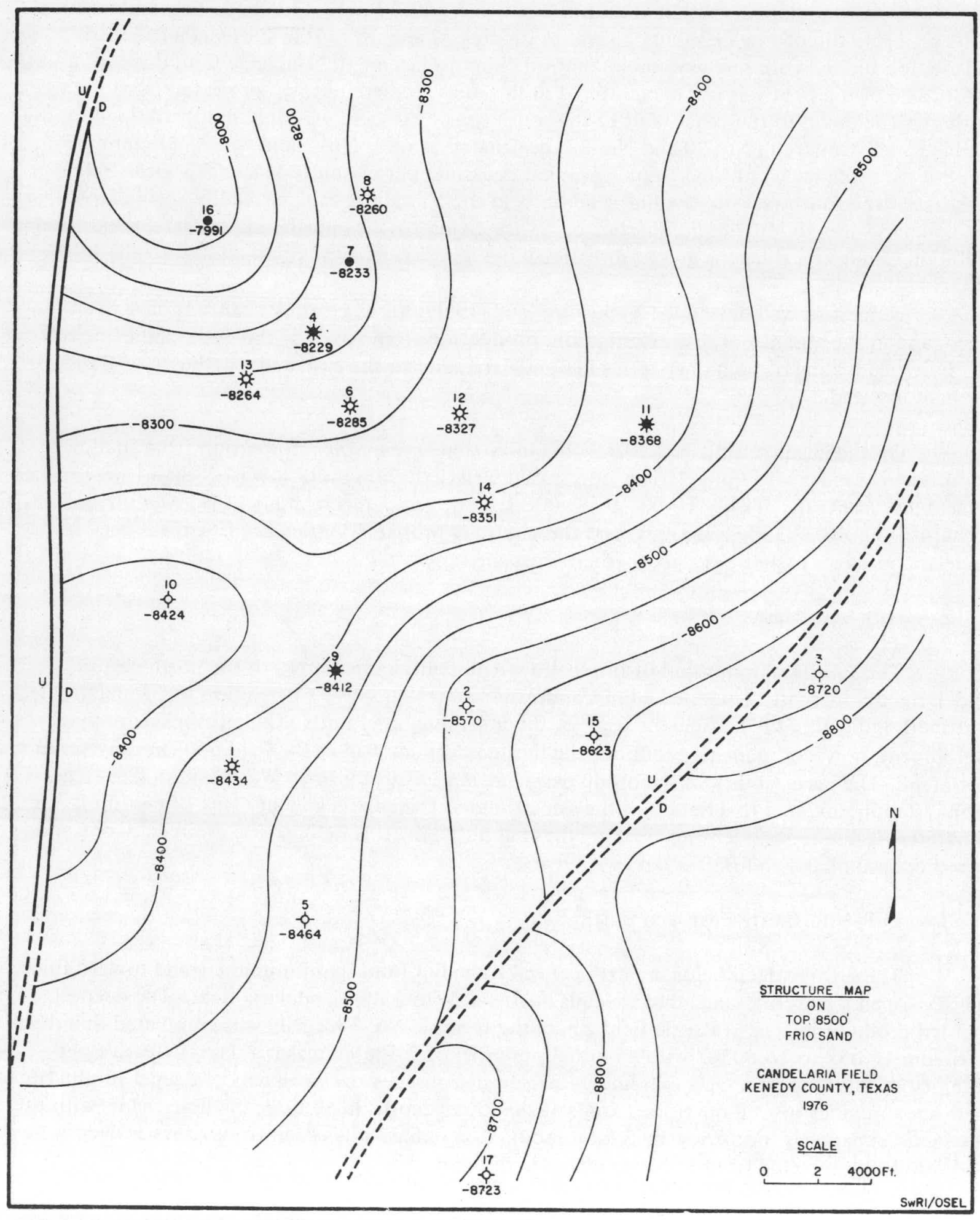

FIGURE: 37. STRUC"TURI: MAP ON TOP 850) ITT I:RIO SAND CANDELARIA IIIILD, KEINI:DY COUNTY, TEXAS 


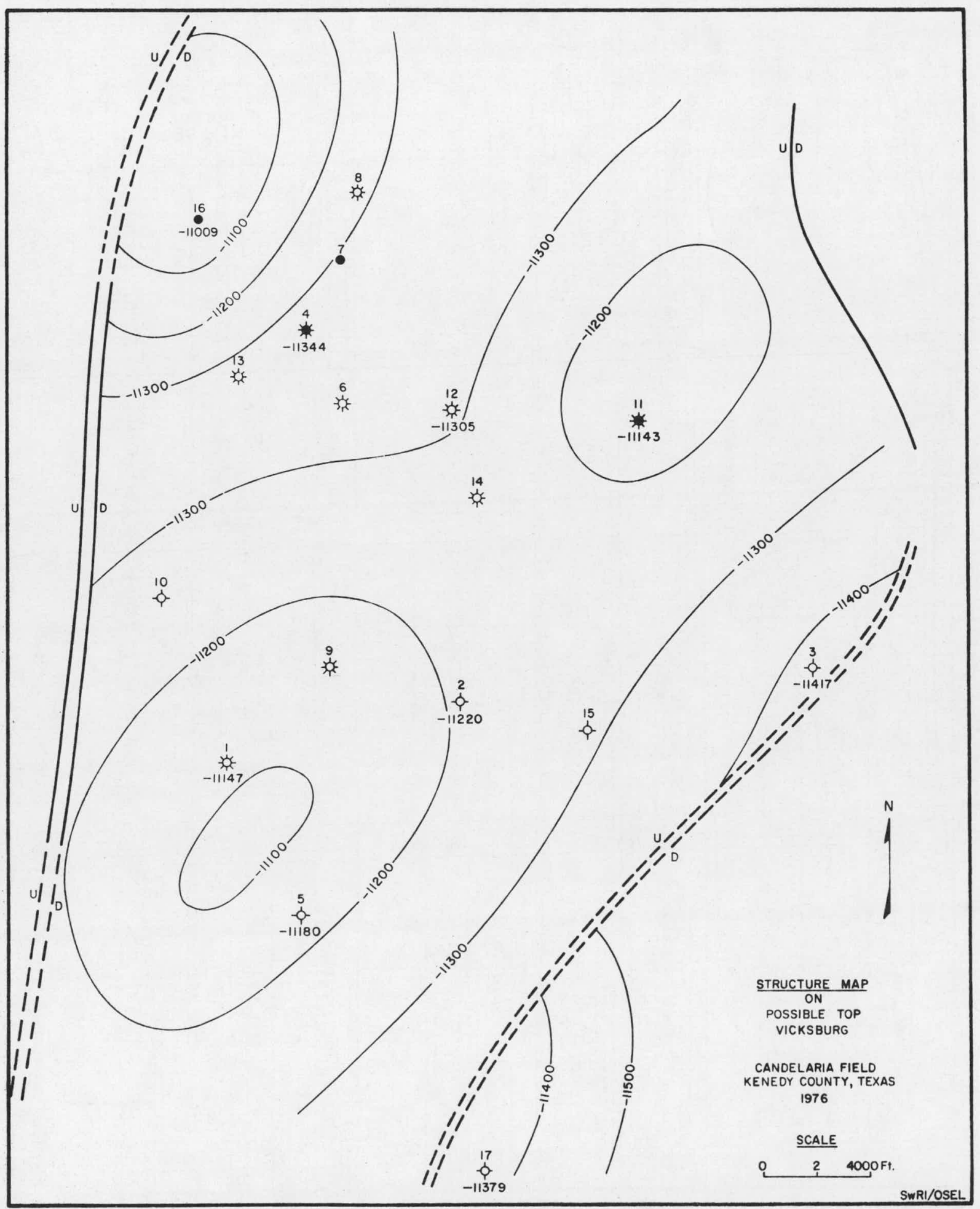

FIGURE 38. STRUCTURE MAP ON POSSIBLE TOP VICKSBURG

CANDELARIA FIELD, KENEDY COUNTY, TEXAS 


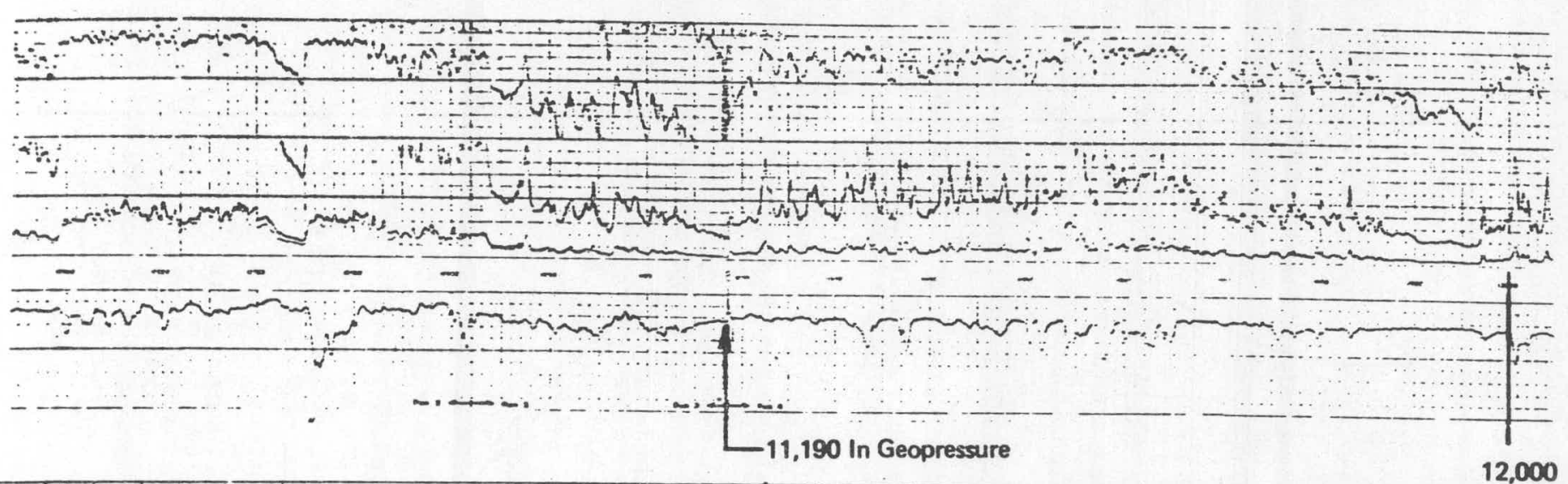

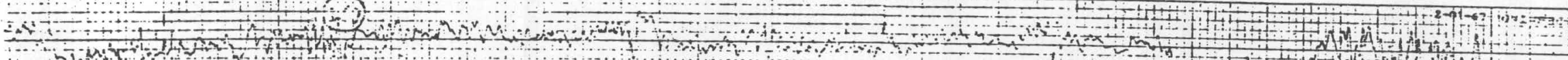
Pand (a) -

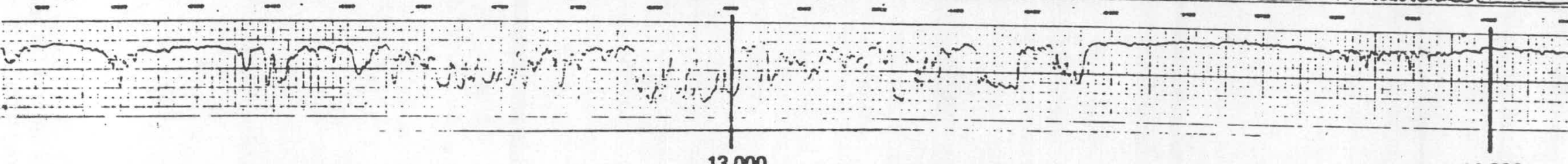
ard ard (n)

ond a

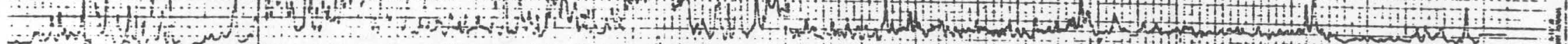

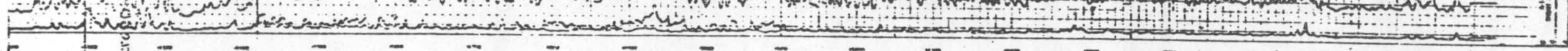

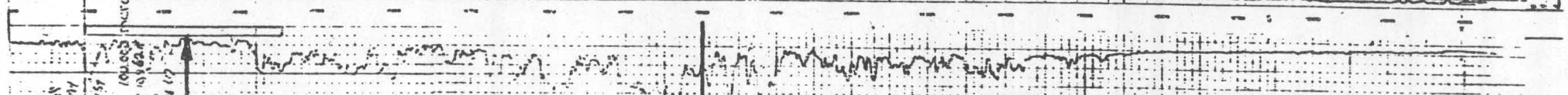

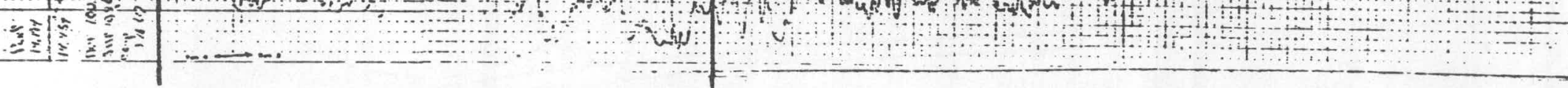

Gas Production

IFIGURE 39. LOG SECTION OF GEOPRESSURED SEDIMENTS PENETRATED IN SARITA FIELD, KENEDY COUNTY,

TEXAS. Top of Geopressure 10,950 ft; Recorded BHT $=306^{\circ}$ at $16,000 \mathrm{ft}$

(Humble \#1 3 East "B") 
$15,200 \mathrm{ft}$ with reasonable possibility of producing fluid. There is a total of nearly $1000 \mathrm{ft}$ of good, well-developed sand between the top of geopressure and $16,000 \mathrm{ft}$.

Baffin Bay continues the same trend, with less well-developed Vicksburg sands and lower permeability. The best prospect in the northern part of Kenedy County is probably in the Sarita area. However, the temperature gradient is relatively low with the $300^{\circ} \mathrm{F}$ geotherm located at approximately $14,000 \mathrm{ft}$. Correlation of the individual sand units between fields is not possible, and it is likely that lenticular sands and limited aquifer size are the rule. The general area is, however, worthy of further consideration, because of the sands at depth in the Vicksburg.

\section{Sorillo}

The geopressured production in Sorillo field is in a south extension of an old, shallow field in the northwest corner of Kenedy County. The single well geopressured producer has nothing to recommend the area as a geothermal prospect. The well produces from a thin Vicksburg stringer at 11,600 ft and there is no further sand development indicated to the total well depth of 13,500 ft. The top of geopressure is located at approximately $10,000 \mathrm{ft}$ and the geothermal gradient is low. The depth of the $300^{\circ} \mathrm{F}$ geotherm is at approximately $14,000 \mathrm{ft}$.

\section{Tordilla-Stillman Area}

Two geopressured producing fields were located in the southwestern corner of Kenedy County near the Hidalgo County border. Both produce from lower Frio Sands near the top of geopressure, and while permeability is as high as $8.0 \mathrm{md}$, there is no indication that Vicksburg prospects are good. The $300^{\circ} \mathrm{F}$ geotherm is at approximately $13,000 \mathrm{ft}$ in this area.

\section{Summary of Kenedy County Investigation}

The best geothermal prospects in Kenedy County occur in a diagonal belt from the Candelaria field area northeast to El Paistle and Sarita. Particularly on the downthrown side of the large faults, Vicksburg sand development is good in many of the wells investigated. Correlation between sand units is extremely tenuous, however, and the probability of small, lenticular aquifers of limited extent is high. The best prospect appears to be in the Sarita field area, although no favorable reservoir information was uncovered. Permeability is low as is the geothermal gradient. But deep Vicksburg sands are present, and adequate testing should be accomplished. The deliverability of water sands at great depth is unknown.

\section{Hidalgo County}

Twenty of the forty-seven geopressured fields identified during the study were located in Hidalgo County. These fields may be grouped with the three major fault systems under whose influence their structures developed. Six of the fields, located near the western boundary of Hidalgo County, are similar to fields in central Brooks County, along the Frio-Vicksburg flexure. Four fields slightly to the east produce from sediments controlled by the Tabasco fault. The remainder are roughly oriented along the huge McAllen-Alazan fault system, which extends from southern Hidalgo County through Kenedy County and beyond.

The four easternmost fields, although listed with those on the McAllen fault, are actually the result of a fourth system, not usually considered a major flexure, known locally as the Weslaco 
fault. It should be understood that these categories are only broadly defined. Each major fault system is composed of almost countless branches, and unnamed transverse faults are commonplace.

The trend as one moves from north to south into Hidalgo County is one of increased faulttrapping in the south, with small individual fault blocks the rule. To the north, in Kenedy and Brooks Counties, the trend is toward less complex faulting with increasingly frequent sand lensing.

\section{Western Hidalgo County}

The Frio-Vicksburg flexure, to the west of the Hidalgo county line, has been described previously in this report in connection with Brooks County. That general description applies to western Hidalgo County, with gradual thickening of Vicksburg sediments to the south. Sand development in the region generally shows improvement over that in Brooks County, but faulting becomes more complex. Six geopressured fields were identified along this trend. They are: (1) South Kelsey, (2) McMoran, (3) McAllen Ranch, (4) Arrowhead, (5) McCook, and (6) Jeffress. These fields all produce from Vicksburg sediments and the geopressured production occurs at depths as great as 14,000 ft. Producing zones in each of the fields are typical, with small individual reservoirs and fault closure the rule. Even within the two largest fields, McAllen Ranch and Jeffress, it is difficult to obtain correlation between more than two wells in the same productive zone. Faulting increases in complexity with depth. The region can be typified by discussion of these two major fields.

\section{a. Jeffress Field}

Jeffress is a large prolific gas field in west central Hidalgo County with the highest geothermal gradient in the county. Geopressured zones can be identified at depths as shallow as $6000 \mathrm{ft}$, but the average top of geopressure lies between 7000 and $8000 \mathrm{ft}$. Current gas production is from isolated sand elements from 6,000 to $13,500 \mathrm{ft}$ in depth, separated by complex faulting and typical of barrier-bar deposition and lensing. Abnormal pressures increase rather gradually with depth, from approximately the top of the Vicksburg formation. Intermediate casing is normally set near $7000 \mathrm{ft}$, and usually a second intermediate string must be set at depths between 9,500 and $10,000 \mathrm{ft}$. At a depth of $10,000 \mathrm{ft}$, the pressure gradient is typically above 0.9 . Faulting becomes more complex below the blanket sand known as the Vicksburg " $S$ " sand. Below the Vicksburg " $T$ " sand, correlation between individual units becomes extremely tenuous.

These two sand bodies, the " $\mathrm{S}$ " and the "T," are shown on the type-log in Figure 40. They are generally well developed, and thicken appreciably on the downthrown side of the several faults that cut the field. These faults are shown in the two structure maps in Figures 41 and 42 , which also show the increased faulting with even moderate increases in depth. We consider these two sands to be of interest and worthy of testing, because the depths are moderate, testing should be simple, and the likelihood of producing water saturated with dissolved gas is excellent. Although the temperatures at this depth are not high, they exceed $250^{\circ} \mathrm{F}$ in the Vicksburg " $\mathrm{T}$ " sand.

A number of outstanding questions can best be approached by testing geopressured sands at depths and under conditions as moderate as possible. These include experience with gas production from water solution, experience with corrosion and scale problems with south Texas geothermal fluids, and attempts to produce multiple sand sections at different depths in the same well. Jeffress' shallow Vicksburg sands are likely to be continuous, and successful operation of a well here would add a great deal to the background of knowledge on the subject of geopressured water production. 

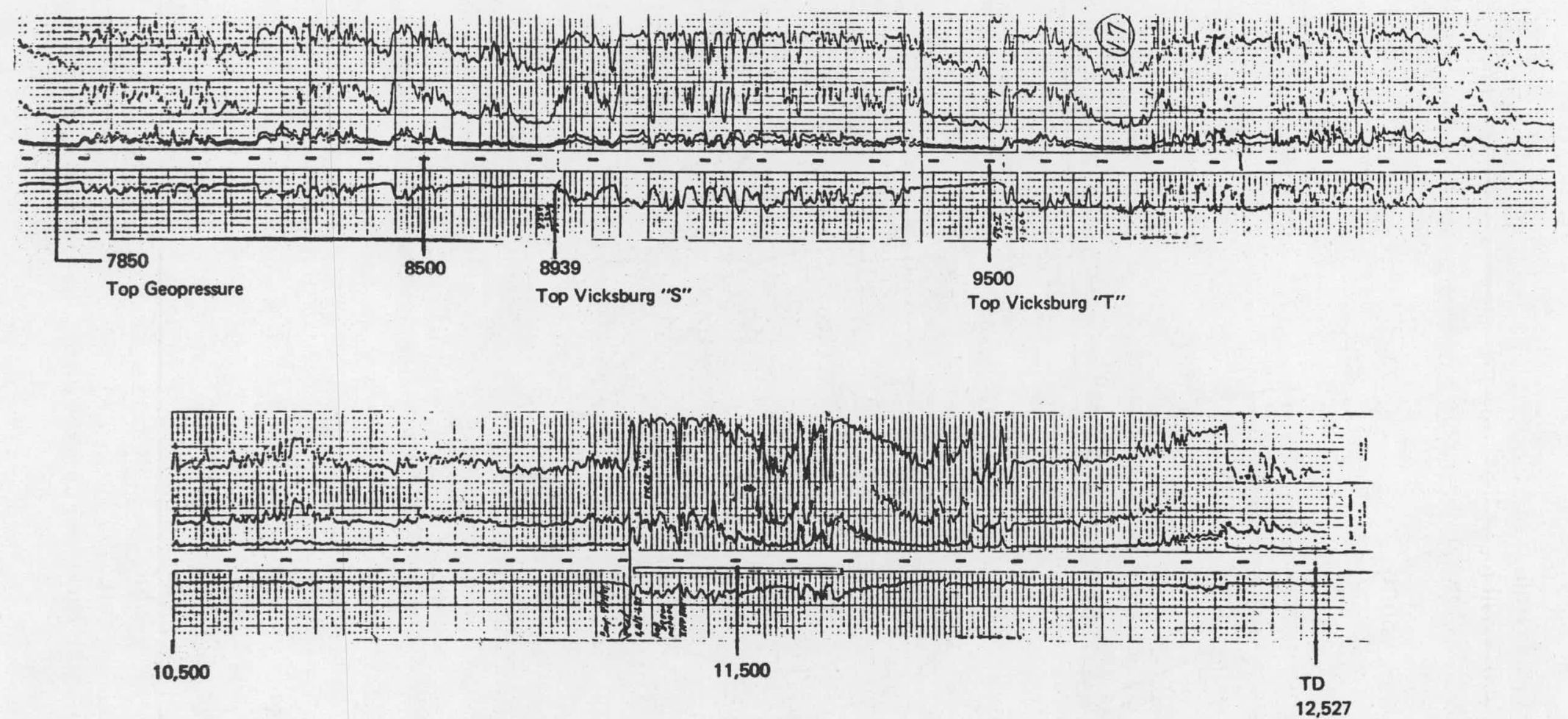


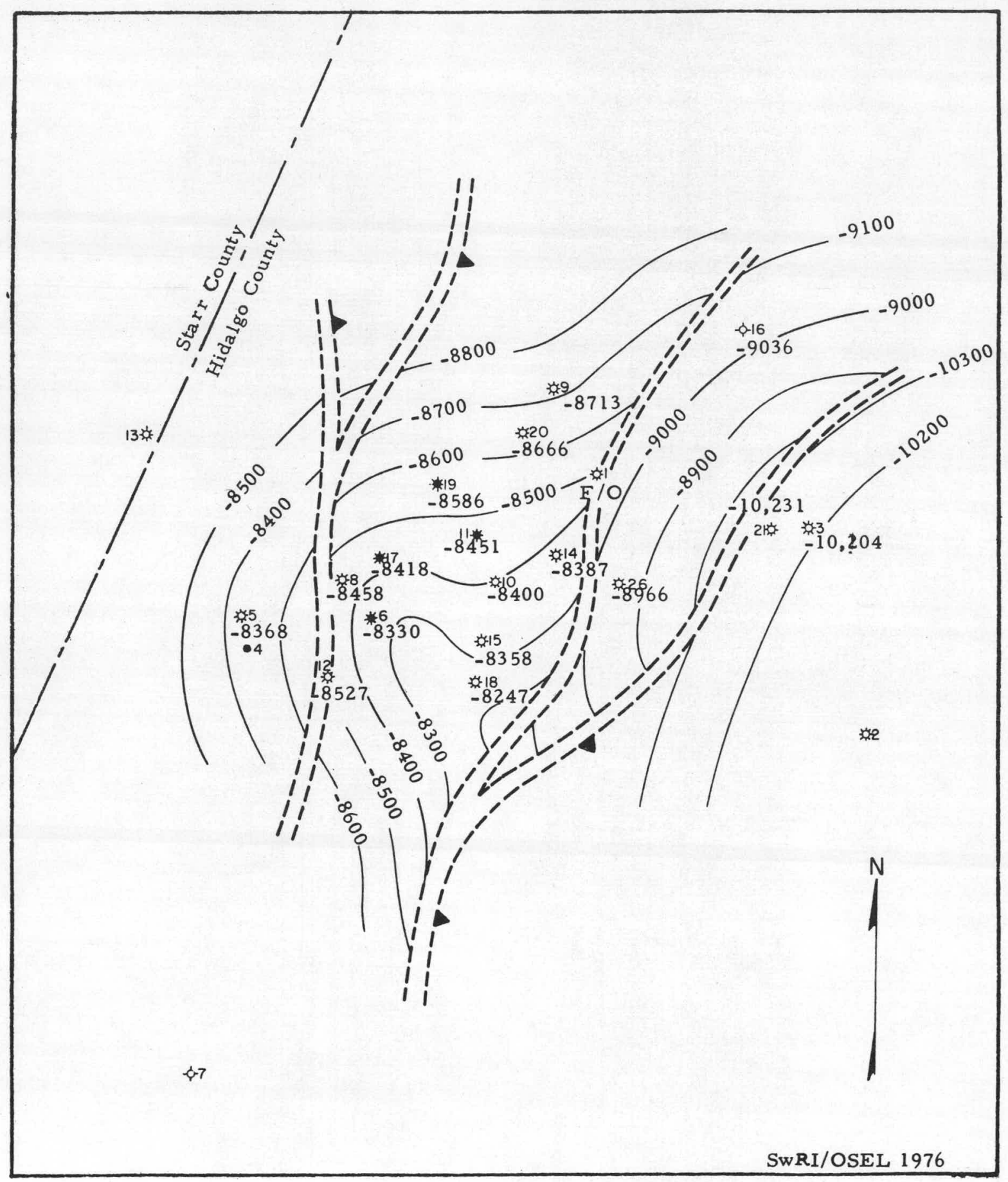

FIGURE 41. STRUCTURE VICKSBURG “S” SAND, JEII'RLSS FIELD, HIDALGO COUNTY, TEXAS 


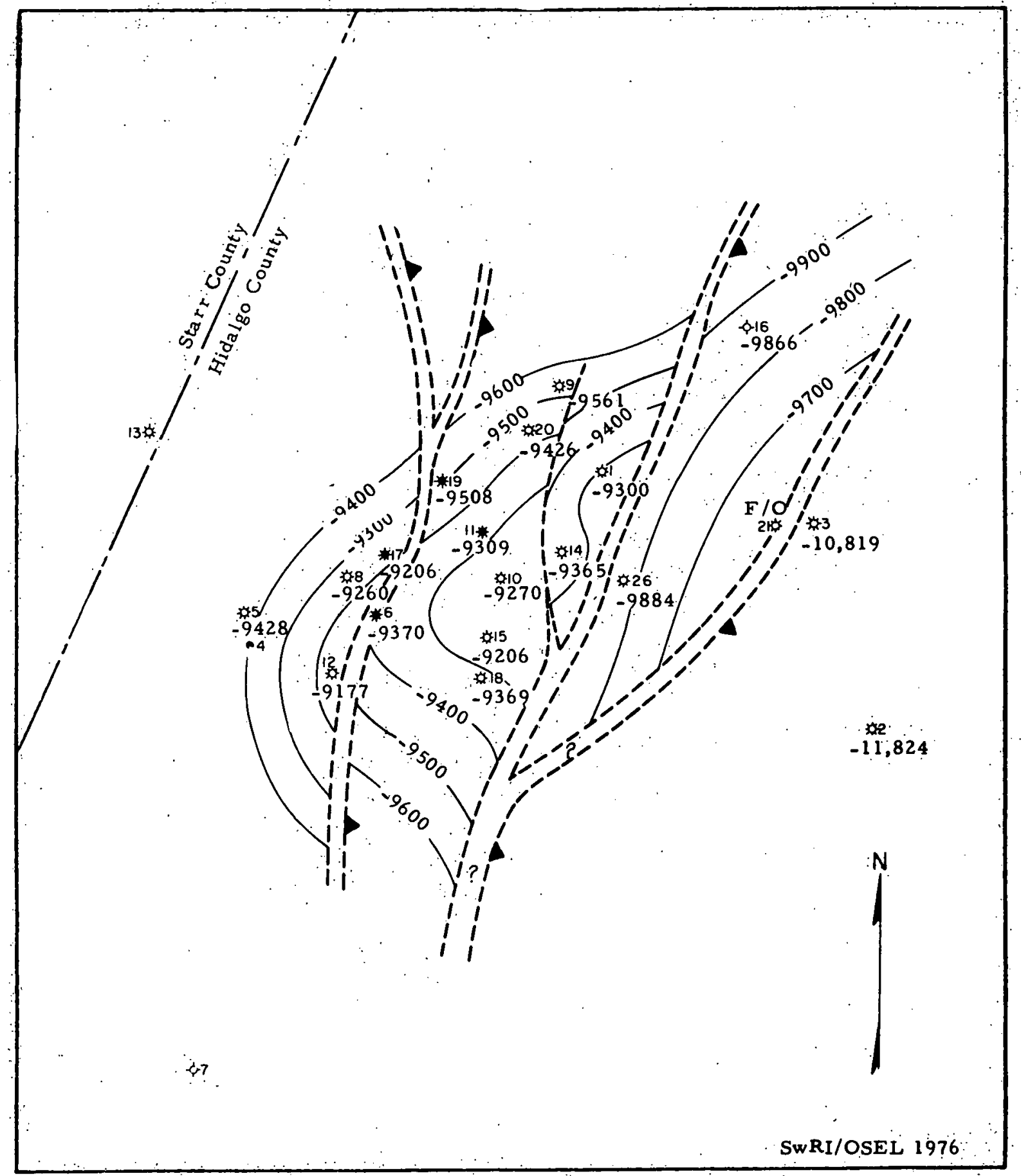

FIGURE 42. STRUCTURE VICKSBUURG “T” SAND, JILIIRI:SS IIILLD, HIDALGO COUNTY, TEXAS 


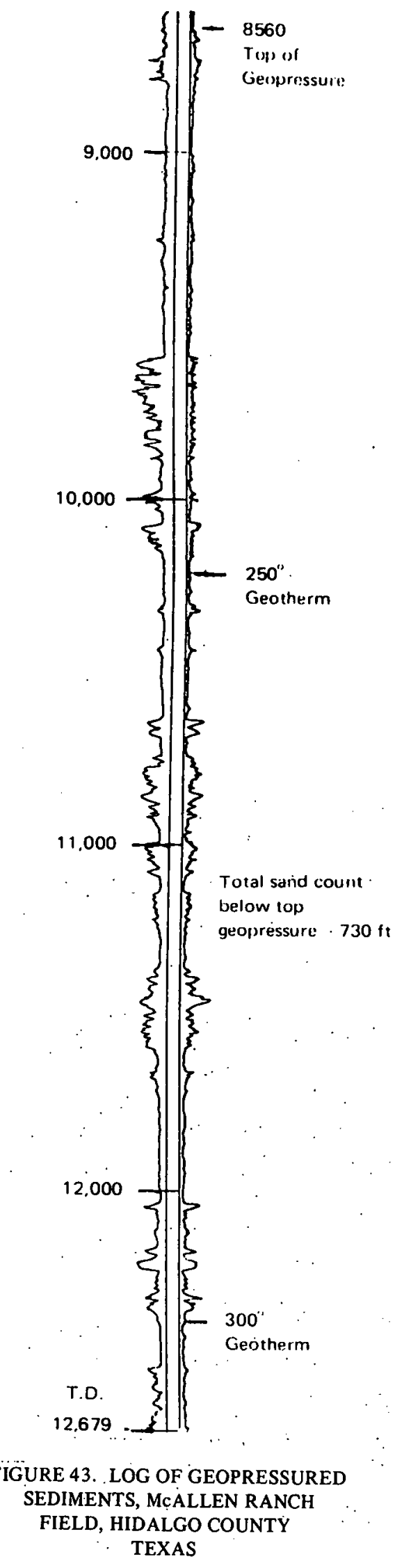

The possibility of deep water production in Jeffress is doubtful; reservoir properties at depth are poor and the sands discontinuous.

\section{b. McAllen Ranch}

McAllen Ranch is a large Vicksburg gas field east and north of Jeffress. It is typical of three smaller adjacent fields (south Kelsey, McMoran and Arrowhead). Structurally, McAllen Ranch field is dominated by two faults. one of which is responsible for most of the sand development in the field, the other cutting the field production into two components. Wells produce gas and condensate at depths ranging from 10,000 to $14,000 \mathrm{ft}$. Deep Vicksburg sands are numerous, and the geothermal gradient is high. The depth of the $300^{\circ} \mathrm{F}$ geotherm is approximately $12,000 \mathrm{ft}$. However, the permeability is very low, and production of water at high flow rates extremely doubtful. A type-log of McAllen Ranch is shown in Figure 43, and structure maps on . two consistent Vicksburg sands are shown in Figures 44 and 45 . Deeper sands are much more elusive and correlation difficult.

In spite of its size and relatively high temperature gradient, the less well-developed upper zones make MçAllen Ranch not as attractive as Jeffress for a shallow test, and the lack of encouraging reservoir parameters at dep th give neither field a good chance for high-temperature production.

\section{Tabasco Fault Area}

Four relatively unimportant fields, from the geothermal standpoint, are grouped along the Tabasco fault, a minor system in the sou thwestern part of Hidalgo County. These fields are, by map number, (7) Monte Christo; 


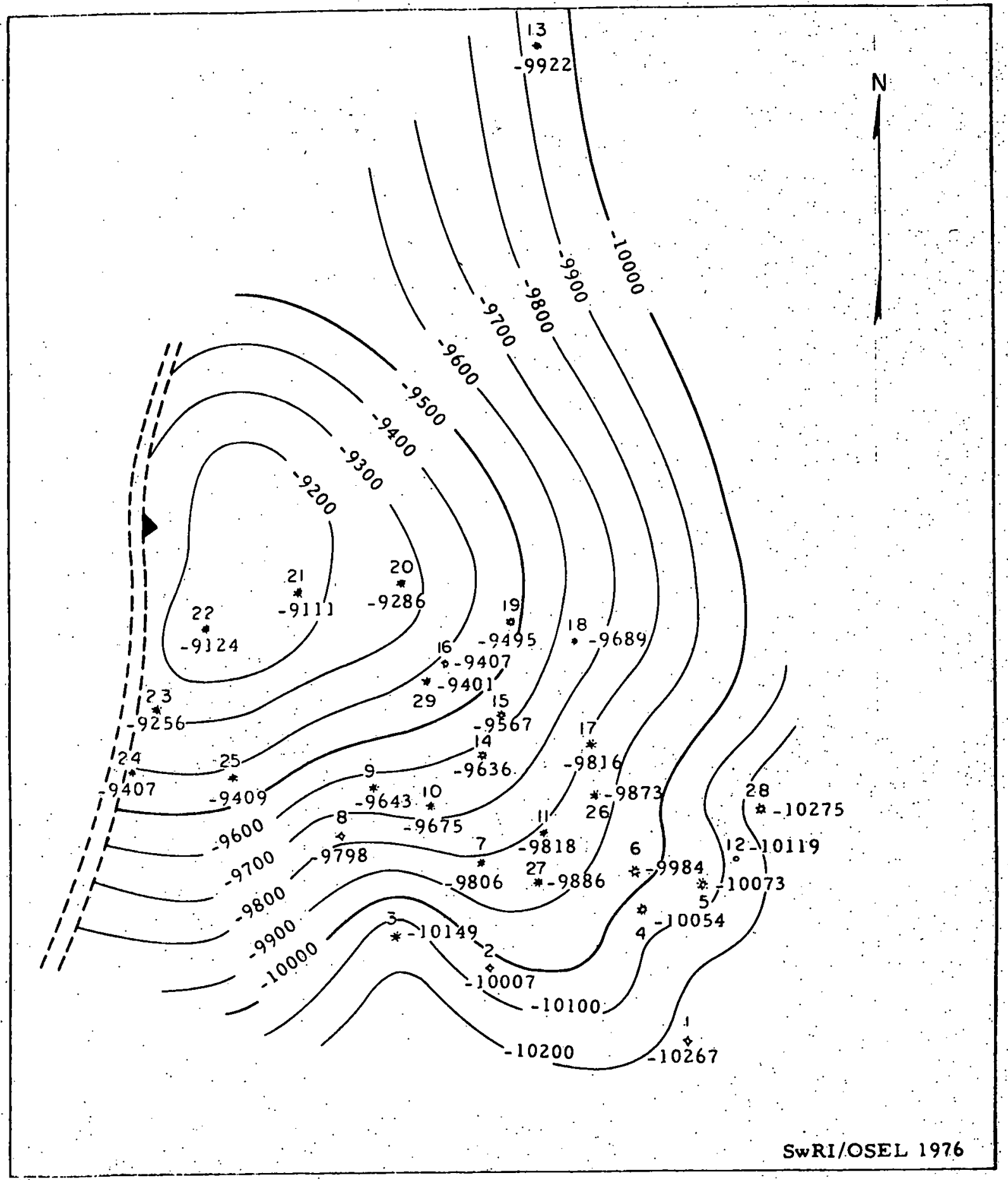

l:I(:URI: 44. STRUC"IURI! TOP VIC:KSBURG "I," SANI), MCALLI:N RANCH, IIIDALGO COUNTY, TJXXS 


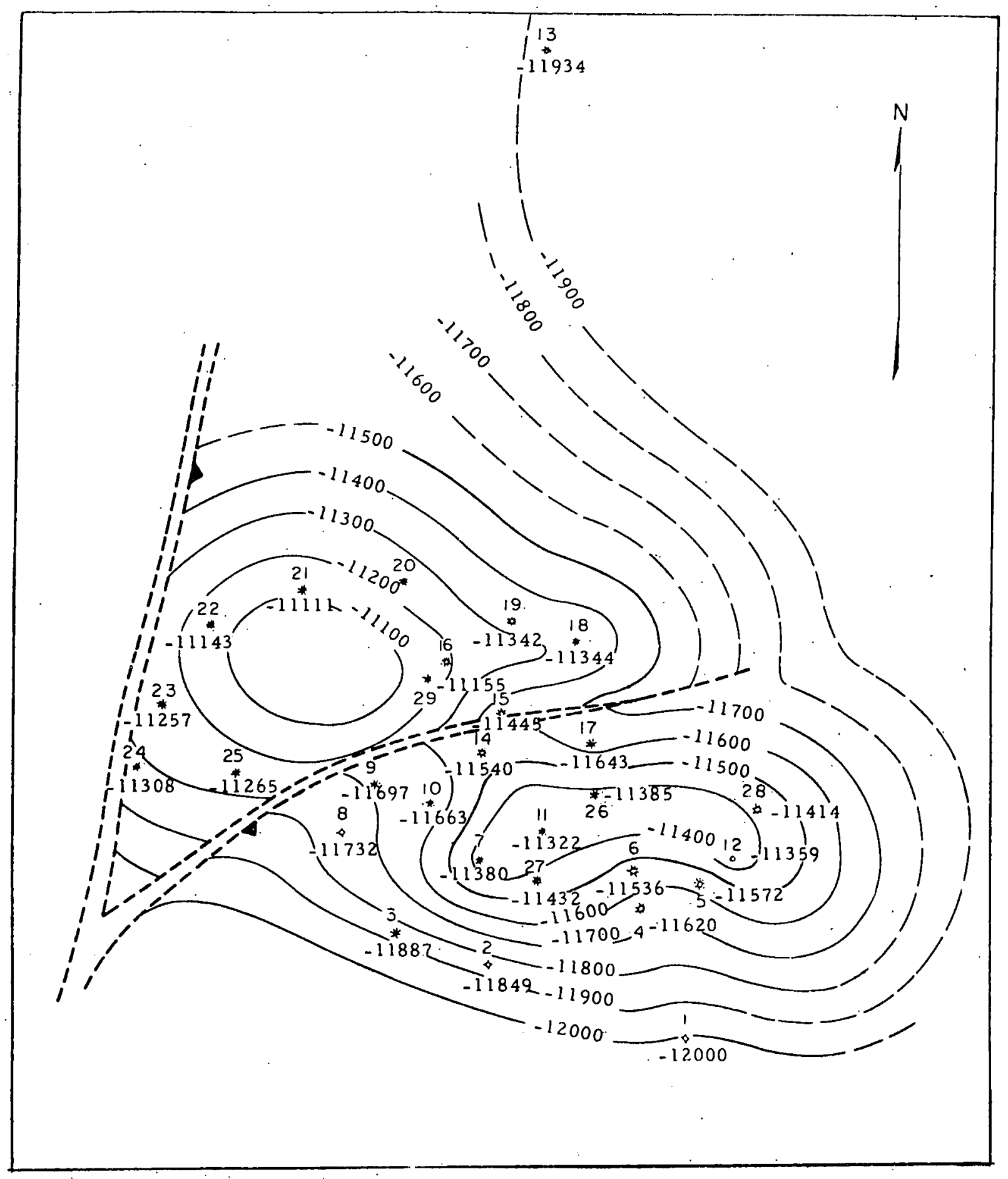

FIGIIRL: 45. STRUCTURE: TOP VICKSBUR(; "S" SANI), MUAIIIIN RANCII, IIII)AI,(;O ('OUN'IY, 'TI:XAS 
(8) Foy; (9) Oblate; (10) Santellana. The largest of these is Monte Christo, producing from lower Frio and upper Vicksburg sands ranging in depth from 6000 to below $11,000 \mathrm{ft}$. Top of geopressure is at approximately $8600 \mathrm{ft}$. Sand development below $11,000 \mathrm{ft}$ is poor. In the deepest test in the area (Shell No. 5 Hamman Ranch), some shaley sand of generally poor quality and limited extent was located between 16,400 and $16,900 \mathrm{ft}$. Temperature at this depth is $350^{\circ} \mathrm{F}$ or more. The best sand development is from 9,000 to $10,000 \mathrm{ft}$, but this sand is known to have low permeability.

The remainder of the fields are not significant, each containing one or at the most two wells producing from small abnormally pressured reservoirs. Sand buildup along the Tabasco fault has apparently been restricted to shallow sediments. A deep test in the Foy area discloses virtually no sand at all from 6,000 to $12,000 \mathrm{ft}$. Although the temperature gradient is good here, reservoir prospects are poor. We do not consider the Tabasco fault area to offer attractive testing possibilities at this stage.

\section{The McAllen Fault-Lower Hidalgo County}

The McAllen fault, dividing the county to the east of center, is one of the largest growth fault systems on the lower Gulf Coast. It has been active throughout the geologic history of the area and was probably caused by structural weakness in the basement rather than by simple slumping. According to Collins (1967), the earliest indication of the fault is the steep westward (reverse) dip of the lower Frio beds in the McAllen field, indicating thickening into the fault. Each successive bed was deposited contemporaneously with fault movement and therefore thickens into the downthrown side, away from the basin. The tremendous amount of deposition associated with the Rio Grande embayment, coincident with the activity of this huge fault system, created enormous reservoir possibilities for both petroleum (which it has produced prolifically) and for geothermal fluid all along its length. The large McAllen-Pharr field area, with numerous separate producing reservoirs, and the Edinburg field just to the north, are situated on this thickened deposition.

The Weslaco fault, a minor system to the east is largely responsible for Frio and upper Vicksburg sand development in four other fields nearby. These fields in the Weslaco-Mercedes area are of interest because they contain the least saline water of any fields studied.

\section{a. McAllen, Pharr, and S. Edinburg Fields $(13,14,12)$}

A promising area for the occurrence of continuous geopressured reservoirs of broad areal extent is in the vicinity of the McAllen-Pharr and the south Edinburg gas fields. These fields are situated between two north-south trending fault systems, the McAllen fault and the Donna fault. The sedimentation and structure of the area were controlled primarily by the massive McAllen growth fault to the west of the fields but in part by the relatively stable area created to the east by the Donna fault. The east-west trending Shepherd fault, with several thousand feet of throw, limits the fields on the south. A type-log of McAllen-Pharr is shown in Figure 46.

Gas and gas condensates have been produced from more than a dozen Frio-Vicksburg sands between the depths of 5,800 and 13,700 ft. In the upper portion of the geopressured section (Hansen Sand), the production occurs in a large stratigraphic trap; deeper production is from small fault blocks, with the beds dipping generally away from the basin. Of principal interest in this study are the lower Frio-Vicksburg sands of the Marks and Bond series and below, where the temperatures are in the range of $300^{\circ} \mathrm{F}$ and higher. The Marks and Bond series alone contain as much as $800 \mathrm{ft}$ of sand, with some individual sand beds more than $100 \mathrm{ft}$ in thickness. According to Collins, most of the faults do not disrupt the continuity of the aquifers because the thickness of the sands is greater 


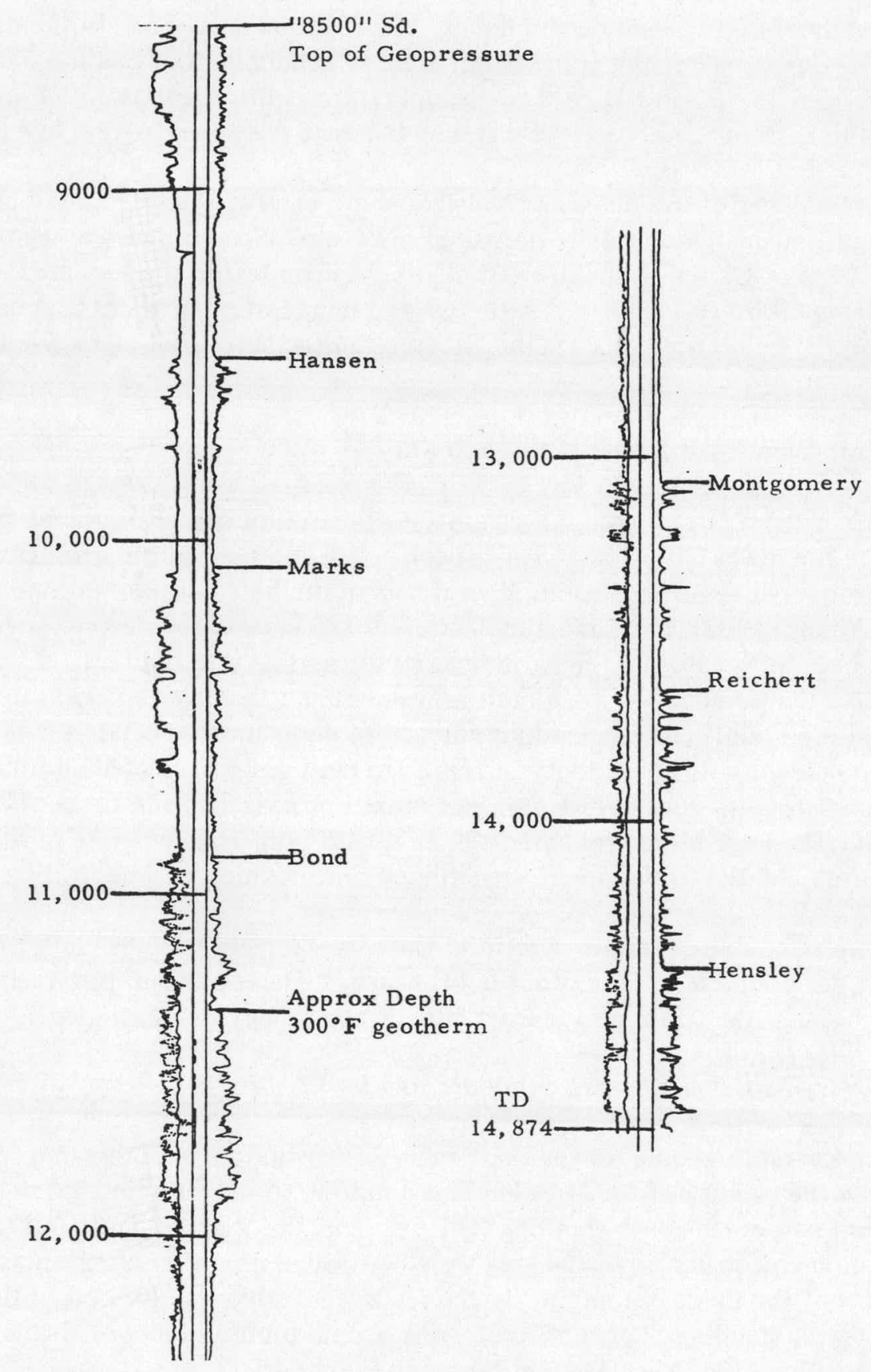

FIGURE 46. WELL LOG OF DEEP, GEOPRESSURED SANDS IN MCALLEN FIELD, HIDALGO COUNTY, TEXAS

than the throw of the faults. Generally, the individual stratigraphic units can be correlated between fields suggesting a potential sand solirce of 20 to 30 square miles or even more.

Figure 47 is a strúcture map; on the top of the Marks sand. Here, correlation between McAllen-Pharr and South Edinburg fields is so definite as to strongly suggest continuity over the area between, even though direct control is limited: 


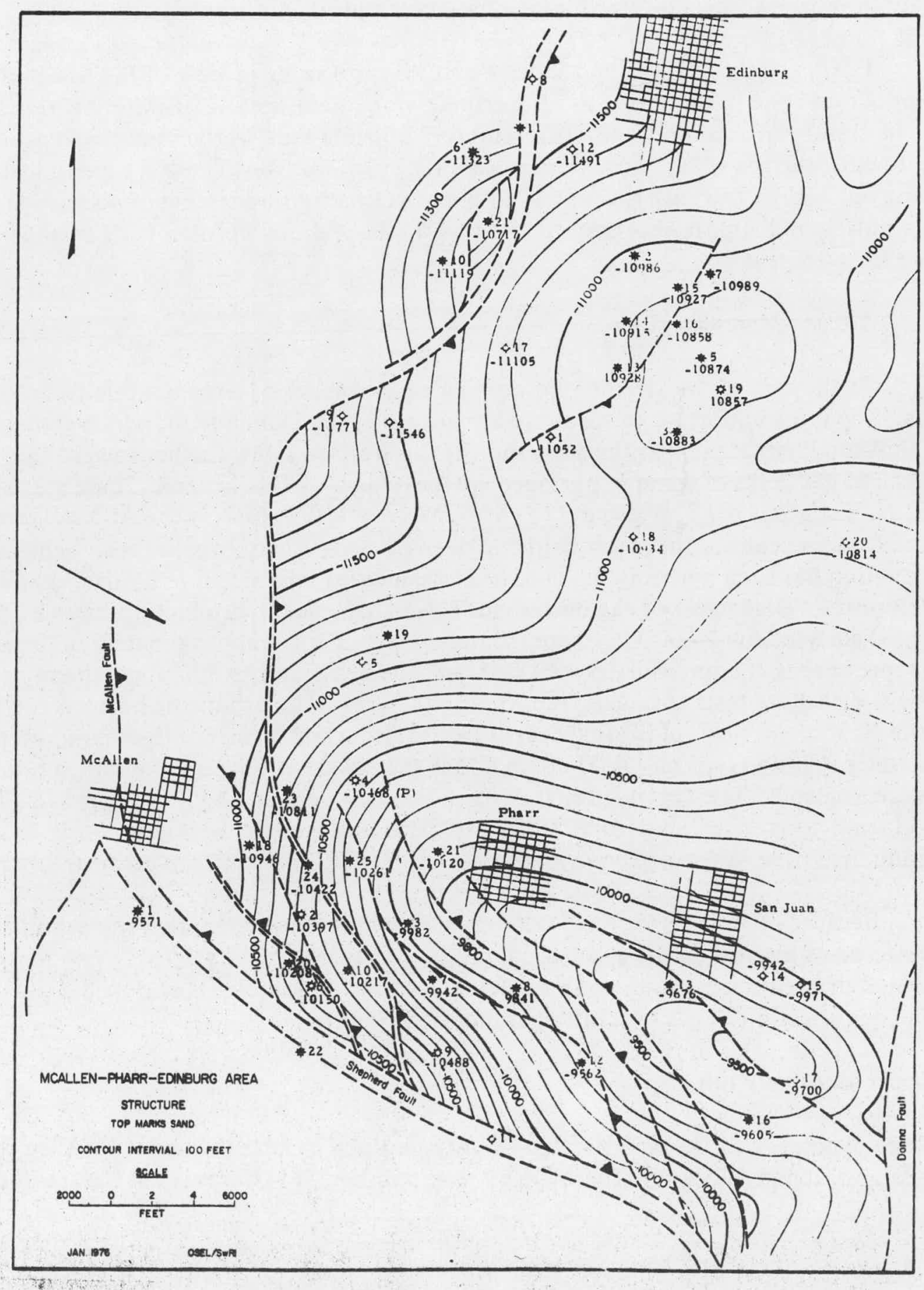

FIGURE 47. STRUCTURE TOP MARKS SAND MCALLEN-PHARR-EDINBURG ARLA 
Several tests in the McAllen-Edinburg area might be profitable to pursue. First, the thickening of sediments into the McAllen fault, to the west of the producing fields, is known to yicld sand intervals of great vertical extent. For example, the 8500 -ft (Frio) sand itself is nearly $1400 \mathrm{ft}$ thick at McAllen, and the Marks-Bond series thickens from $540 \mathrm{ft}$ at Pharr to $1200 \mathrm{ft}$ at a distance of one mile from the McAllen fault. These sands, below the gas-water contact, have not been adequately tested, and this is an excellent place to do so. Gas content, permeability, and the ability to successfully flow a long interval of water-bearing sand all need confirmation.

Testing of the Marks-Bond series seems less promising in view of the low permeability in the gas-production zone in that horizon. Nevertheless, adequate testing of water-bearing strata off-structure has not been accomplished. It is remotely possible that, as the sand thickens into the McAllen fault below the gas-water content, permeability may improve. There is a great deal of experience arrayed against this suggestion, but no proof. Off-structure testing of deep, hightemperature sands would appear necessary to test this thesis, and the McAllen fault area is perhaps the best place to attempt it.

\section{b. Weslaco-Mercedes Area}

To the east of the McAllen-Edinburg area lie a series of large but relatively local growth faults. The most important of these are known as (1) the Donna fault, which geologically isolates the McAllen-Pharr area from the east, and (2) the Weslaco fault, further toward the coast. Four geopressured gas fields of some importance are located along this system. These are, by map number, (17) N. Weslaco; (18) S. Weslaco; (19) S. W. Mercedes; (20) Mercedes. All are characterized by massive fresh water sands in the lower Frio and deep into the Vicksburg, in those wells in which the latter formation has been penetrated. The fields are located on a structural "high" known as the "Weslaco uplift." The largest of the deep fields is North Weslaco. Production there is from the Frio at depths slightly below $10,000 \mathrm{ft}$ where the pressure gradient is approximately $0.75 \mathrm{psi} / \mathrm{ft}$, the top of geopressure is at approximately $9500 \mathrm{ft}$, and the depth of the $300^{\circ} \mathrm{F}$ geotherm near $13,000 \mathrm{ft}$. Few Vicksburg tests have been reported in the area. The producing horizon correlates well across the $\mathrm{N}$. Weslaco field, indicating only minor faulting and large, continuous aquifers. The low connate water salinity (typically $4,000 \mathrm{ppm} \mathrm{C1}$ ) is the lowest of any area for which reliable water data were available. The type-log for the North Weslaco field is shown in Figure 48. The principal producing horizon is indicated at 10,200 ft. This is one of the best gas wells in the field. The 15-ft productive zone has an effective $\mathrm{kh}$ value of $17 \mathrm{md}-\mathrm{ft}$, or an average permeability of $1.16 \mathrm{md}$.

Because of the massive sand development and the low connate water salinity, this area would appear to be of interest to the geothermal program. However, the relatively low temperature gradient and lack of encouraging reservoir parameters restrict the usefulness of possible tests in this region, to the identification of gas in solution at moderate depths.

\section{Upper McAllen Fault}

Three geopressured fields in Hidalgo County lie along or near the upper McAllen fault which extends into Kenedy County. These are by map number, (11) Cerda; (15) LaJara; (16) Hargill.

\section{a. Cerda}

Cerda is a small geopressured field of isolated extent producing from thin FrioVicksburg sand elements from 10,000 to $12,000 \mathrm{ft}$. Permeability in the discovery well was over $5 \mathrm{md}$, but offset wells failed to find the producing sand and only two additional wells have produced, 


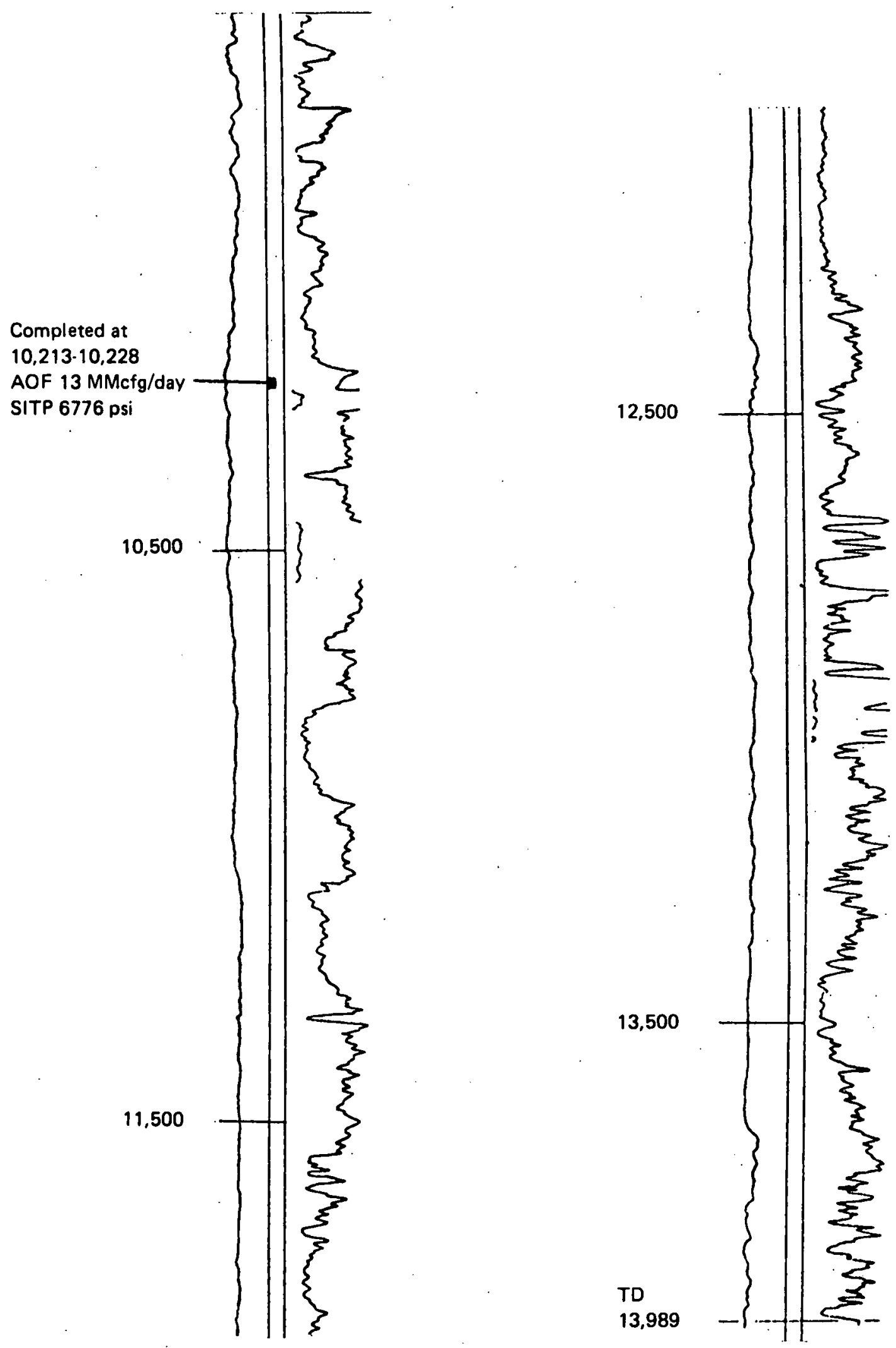

FIGURE 48. TYPE LOG, N. WESLACO FIELD SHOWING MASSIVE DEEP FRIO-VICKSBURG FRESH WATER' SANDS TO 14,000 FT (NORTH.PUMP NO. 2 HARRIS) 
each at separate depths from separate thin sand stringers. The total sand development in the area is poor, the single good gas producer undoubtedly producing from a small sand lens of unusual quality. A number of dry holes in the region give fair control to the area, but the lack of deep Vicksburg sands leaves scant hope for profitable testing.

\section{b. Hargill-LaJara Area}

Both these two fields (Nos. 15 and 16 in.Figure 3) produce from Lower Frio sands of good quality but limited extent near the top of geopressure at approximately $11,000 \mathrm{ft}$. A 14,000-ft test in LaJara logged isolated, well-developed sand elements in the Vicksburg to total depth, but the temperature gradient is only moderate. In the face of generally unfavorable reservoir information, the area has little to recommend it for geothermal interest.

\section{Live Oak County}

Geopressure is common in the deeper horizons of south and south central Live Oak County, and has been identified in six producing gas fields in the Wilcox formation. These fields are all to the east of the Mirando-Gohlke fault, a major growth fault system which, like other major fault systems in south Texas, parallels the coast. Historically, it is along the downthrown side of this system that much of the regional Wilcox petroleum production has been located. Live Oak County, in this regard, may be considered typical of nearby counties along the fault, including Zapata, Webb, Duval, McMullen, Bee, Goliad, and Victoria.

The south Texas Wilcox sands are of Eocene age, and consist of shallow marine and continental facies, ranging from coarse to fine grained, heterogenous, crossbedded and interbedded with silts, clays, peat and lignite. Deposition evidently took place in flood plains in nearshore marine waters, lakes, swamps, embayments, and a wide flat coastal plain traversed by shifting streams, aggrading, degrading, and flooding in much the same depositional environment that prevails along the Gulf Coast today.

During early Wilcox time, the seas were retreating; then fluctuated with slow subsidence of the coastal plains during middle Wilcox; and finally were encroaching in the final period of Wilcox time. The sands toward the outcrop are of different age than the downdip beds; thus, regionally the sand members are not correlatable on dip as time units. In localized areas, and on strike for considerable distances, the sand and shale zones are generally characteristic and electric log correlations can be made with comparative ease.

Structurally, the Wilcox reservoirs in south Texas are characterized by low relief, elongated anticlines associated with normal down-to-the-coast faulting. Usually the structures which close against a fault are on the upthrown block but frequently the structures seem to have been developed simultaneously with the faulting, and the formation dips into the fault on both the upthrown and downthrown blocks.

Northeast of Lavaca County the Wilcox has larger structures which appear to be less dependent on faulting. The lower members of the formation here are often productive, whereas to the southwest, in the region of our interest, the upper members are predominantly more productive. Toward the Rio Grande Valley, the structures a 2 generally fewer in number with less faulting. The predominantly marine facies also tend to cause the formation to be less permeable. 
The type of deposition leads to a high degree of heterogenity of the sands, the characteristics of which often vary considerably from field to field and even within the same reservoir. Accurate prediction of reservoir performance is difficult because of the varying porosity, permeability, and the number of small and larger faults. These features act as barriers or partial barriers to the broad areal movement of hydrocarbons or water. For these reasons Wilcox sands, like Vicksburg sands, must be considered to have many drawbacks as geothermal producers. Nevertheless, in south Texas the temperature gradient to the Wilcox is high, and where reservoir conditions are favorable, production of fluid at temperatures higher than $350^{\circ} \mathrm{F}$ is a possibility.

\section{Individual Fields in Live Oak County}

The locations of the six geopressured fields identified in Live Oak County were shown on the map in Figure 2. All are in close proximity to each other, although structurally isolated. They are (47) Tom Lyne; (44) East Tom Lyne; (45) Kitty Burns; (42) Katz-Slick; (43) Clay West; and (46) Mikeska. Five of these fields are shown on the structure map on the top of the Wilcox in Figure 49. Mikeska is located off the map to the east.

A cross section of the Katz-Slick field, on the section marked "AA," is shown in Figure 50. The severe faulting which is no doubt the controlling factor in geopressure in the field is clearly evident.

Good sand development is general in the area of these fields. Permeability, although spotty, is frequently very good for sands at these depths. The highest permeability values in any reservoirs with equivalent temperatures in the study region were located here, ranging to a high of $8.8 \mathrm{md}$ at $11,500 \mathrm{ft}$.

The best prospect for a relatively large geopressured aquifer in the Live Oak-producing area is south of the principal fault in the Katz-Slick field, along the line of the fault to the northeast (arrow in Figure 50). Two log sections, one from.Well No. 3 and one from Dry Hole No. 8, are shown in Figure 51. Good sand development throughout the Wilcox section holds as one proceeds down the anticline (off-structure), and gives evidence of continuing to do so to the east. The deep Wilcox sand at $14,000 \mathrm{ft}$ in Well No. 8 is at a temperature near $37.5^{\circ} \mathrm{F}$, and we select it as the most favorable high temperature water producing prospect in the entire Study Region.

Well No. 1 adds control to the south, and indicates good sand development continuing in the 10,000 and $12,000-\mathrm{ft}$ sands. This well was too shallow to penetrate the $14,000-\mathrm{ft}$ sand, however,

Other prospects, which lack sufficient control to establish credibility, exist between other major faults in the area, particularly off-structure to the southwest and northeast-of-Elay-Westand Kitty Burns.

The most pressing question at this time is whether or not commercially viable sources of geothermal fluid exist in south Texas, and if so, whether or not such fluid contains methane. It is likely that the abundance of methane in the earth declines with temperature, above some critical point. A source of $375^{\circ} \mathrm{F}$ or hotter water should be tested soon, and verification of gas saturation obtained. In most of south Texas, the prospect of producing $375^{\circ} \mathrm{F}$ water is poor, but in Live Oak County, the possibility of successfully testing such a zone is good. 


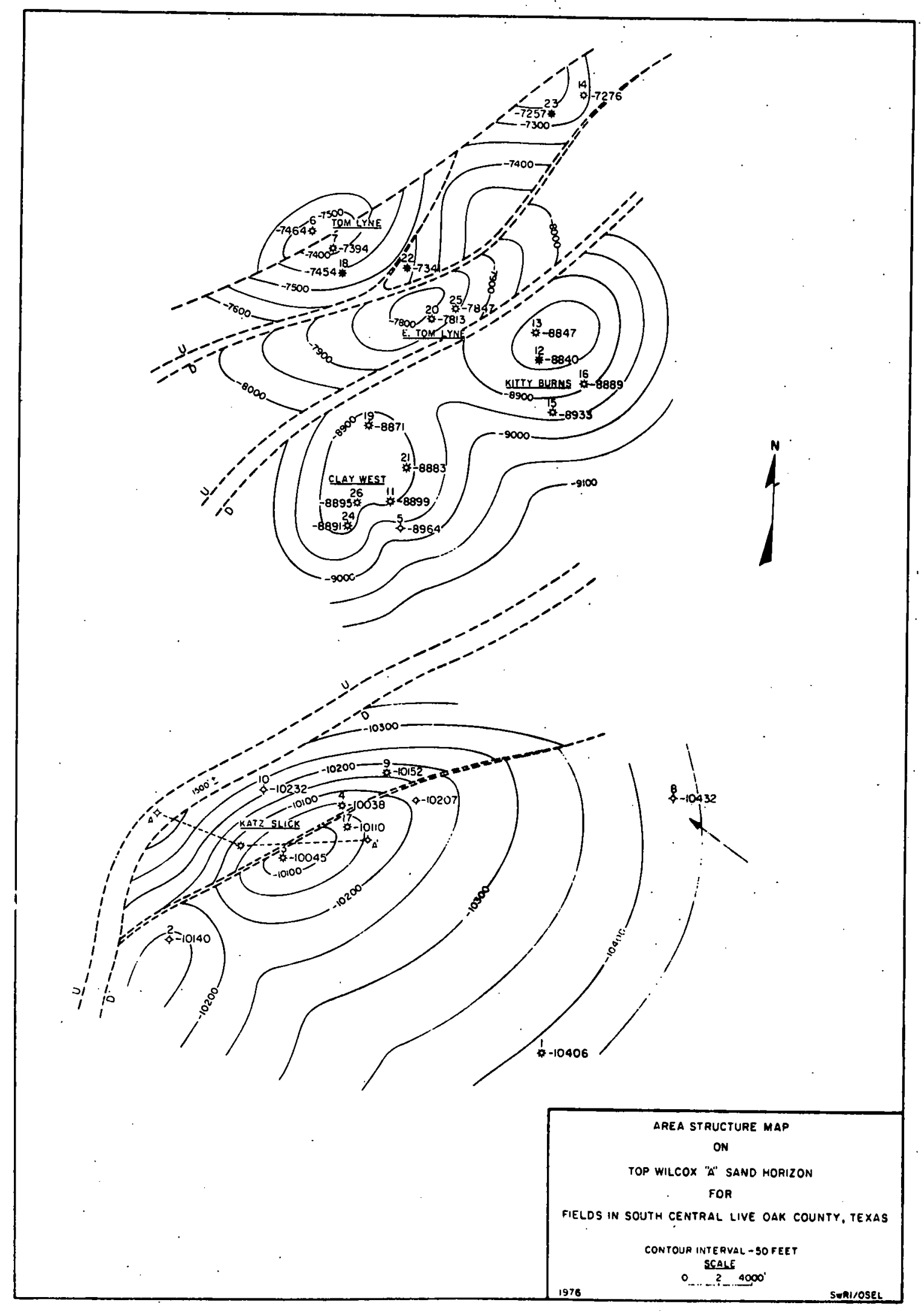

IIGIURL 49. AREA STRUCTURL MAP ON TOP WILCCX "A" SAND IIORI\%ON IOOR IIIILIOS IN SOUIII CLNTRAL LIVLE OAK ('OUNTY, T'LXAS 
9

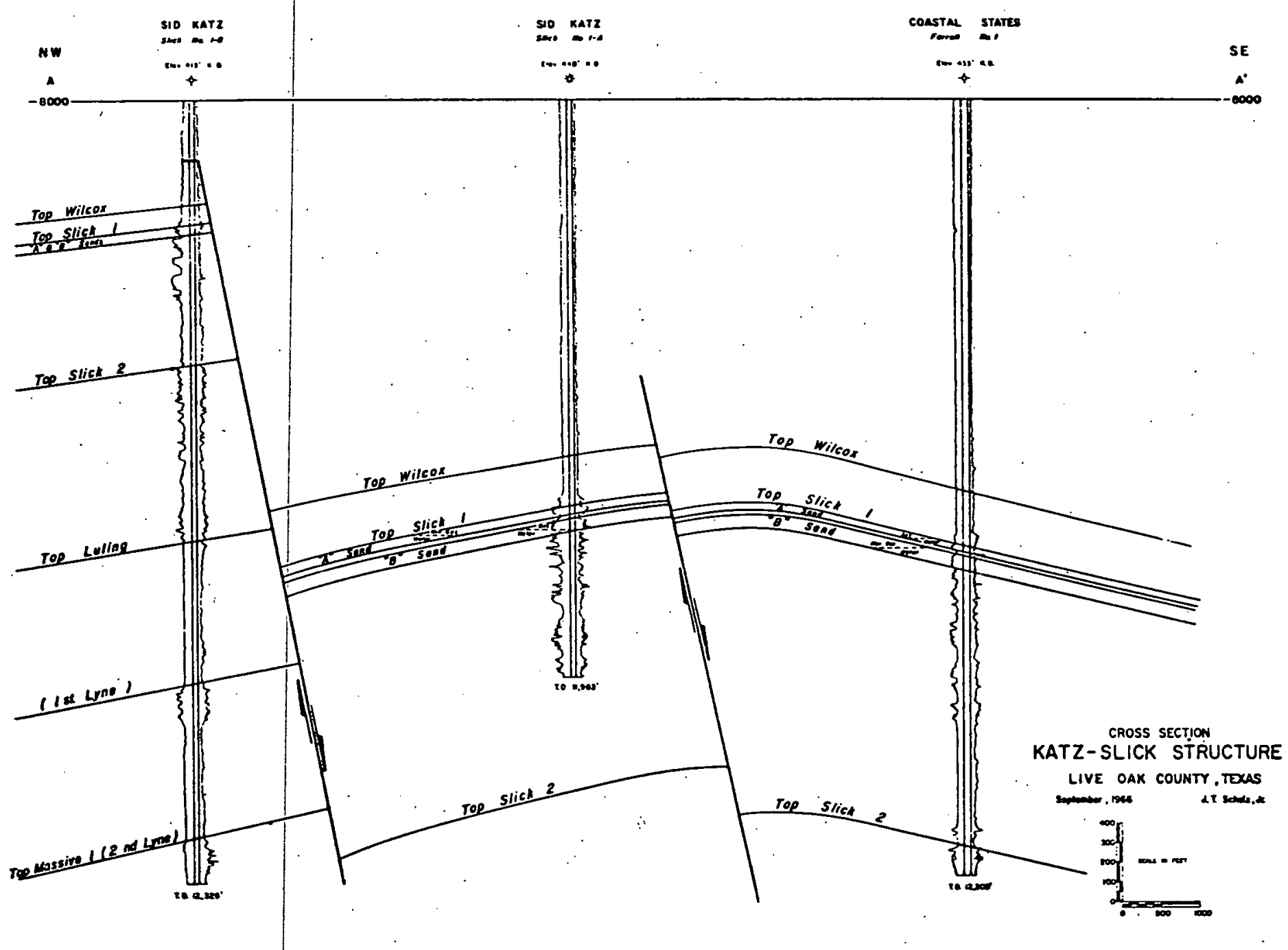

After Shultz, from "Typical Oil and Gas Fields in South Texas," 1967 (used by permission of Corpus Christi Geological Society).

FIGURE 50. CROSS SECTION KATZ-SLICK STRUCTURE, LIVE OAK COUNTY, TEXAS 


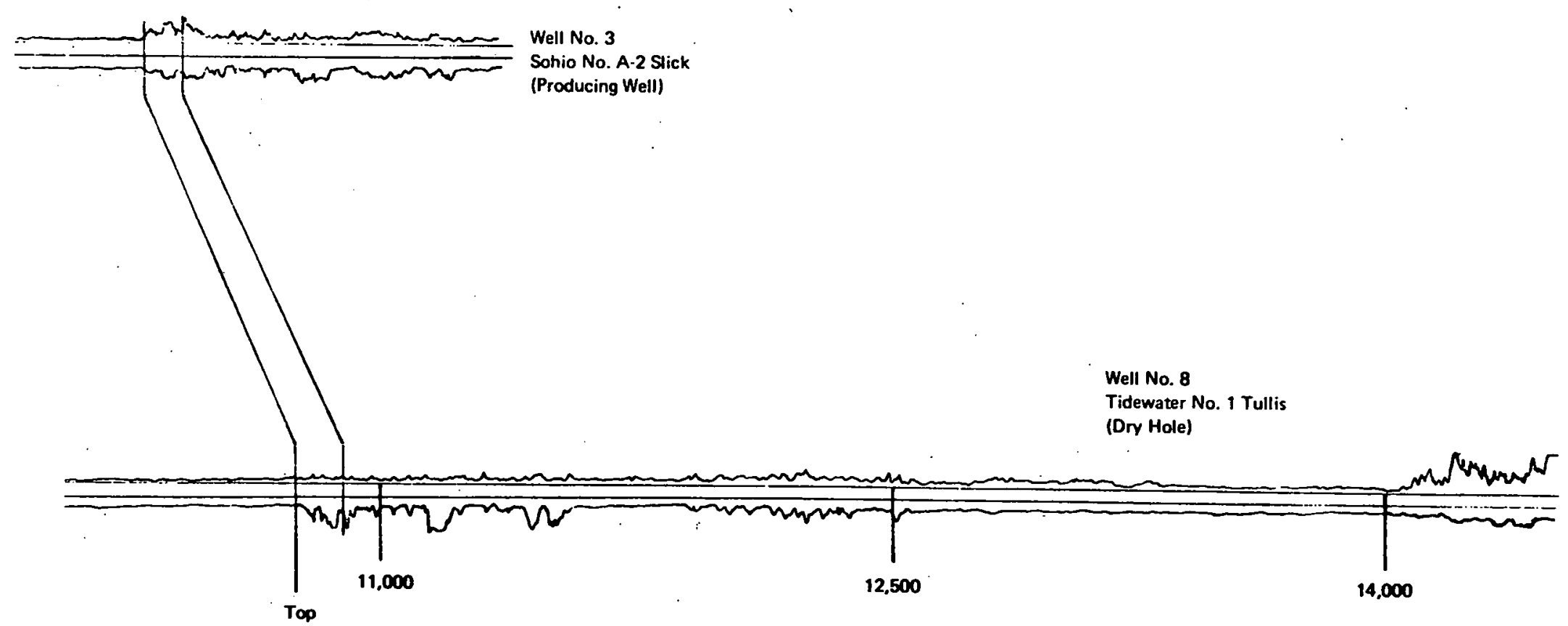

Wileox

FIGL'RE 51 . DEEP WILCOX DEVELOPMENT OFF-STRUCTURE, (WELL NO. 8) TO NORTHEAST KATZ-

SLICK FIELD. LIVE OAK CO.. TEXAS 


\section{Nonelectric Uses of Geothermal Fluid}

Live Oak County is in one of the favorable areas for uranium production in the Southwest. The active development of the resource in Texas is presently restricted to Live Oak and adjacent Karnes Counties, and the location of the Live Oak uranium deposits is roughly coincident with the Wilcox geothermal prospects. The available hot water may complement the leach-production of the underground uranium ore. There are severe problems in considering such activity, but the possibility is at least worth consideration.

\section{E. Cameron County}

- Cameron County has been notoriously disappointing to exploration geologists. Only a handful of producing fields have been successfully completed, and the only geopressured production identified is in the San Martin field in the extreme southeastern corner of the county, where the Skelly No. 1 Gatewood recorded an initial fluid pressure gradient of 0.58 at $9400 \mathrm{ft}$ (Miocene). No deeper production has been discovered in the county, although a number of deep exploration wells lave been drilled. Lack of significant sand deposition in the Frio shale is commonly cited as the reason for the failure to discover good petroleum prospects.

On the basis of production experience, the geothermal potential in Cameron County cannot be accurately assessed. Locations of three deep wildcats, spaced diagonally across the county, can be seen in Figure 3, shown earlier in this report. Examination of these wells gives some insight into the matter. The deepest of the three; in the approximate center of the county (Chevron No. 1 Rodriguez) reached a total depth of $18,500 \mathrm{ft}$. Below the top of geopressure at $12,000 \mathrm{ft}$, the few sands encountered are poorly developed and show little promise. One zone, from approximately 16,000 to $17,000 \mathrm{ft}$, showed fresh water sands (calculated $R_{w}=5,000 \mathrm{ppm} \mathrm{C1}$ ), with total sand thickness of about $200 \mathrm{ft}$. Less well-developed sands from approximately $17,600 \mathrm{ft}$ to total depth may add as much as 100 additional total net feet. The maximum temperature recorded was less than $350^{\circ} \mathrm{F}$. We do not consider Cameron County to offer good geothermal possibilities.

\section{F. Willacy County}

Willacy County, the site of several large shallow fields, has limited deep production, with abnormal pressures identified in three fields in the west central part of the county. Niles and Riggan fields report wells with small abnormal pressure gradients at depths from 9,000 to $10,000 \mathrm{ft}$.

La Sal Vieja is a Frio field with production from slightly below $10,000 \mathrm{ft}$ and an initial fluid pressure gradient of approximately 0.8 . The temperature at this depth is only about $200^{\circ} \mathrm{F}$. There is no deeper production experience on which to base assessment of potential high-temperature reservoirs in the County. The average permeability in the 10,000-ft zone in La Sal Vieja is less than $1.0 \mathrm{md}$, and the depth of the $300^{\circ} \mathrm{F}\left(150^{\circ} \mathrm{C}\right)$ geotherm is approximately $14,000 \mathrm{ft}$. The highest permeability ( $24.0 \mathrm{md}$ ) of any geopressured producing zone in the study region, however, was in the $9400-\mathrm{ft}$ sand in Riggan field. 


\section{CONCLUSIONS AND RECOMMENDATIONS}

The study of south Texas gas fields has produced a number of general conclusions about the region that apply to its geothermal potential. These are discussed in the following paragraphs. In addition, a well-developed assessment methodology has emerged which is applicable to broad areas of the Gulf Coast. Certain specific recommendations are also made with regard to geothermal development in the south Texas region.

\section{A. Summary of Results}

\section{Depth and Occurrence of Geopressure}

Geopressure is evidently a general feature of deeper sediments throughout the study region, and occurs locally at relatively uniform depths. In Live Oak County, geopressured gas production is restricted to the Wilcox formation, east of the large Mirando-Gohlke fault. Abnormal pressures are encountered there at depths generally near $9000 \mathrm{ft}$.

In the lower south Texas study area, the shallowest occurrence of geopressure is along the Frio-Vicksburg flexure, roughly coincident with the western Hidalgo County border and the southeastern half of Brooks County. Here, as in most places in lower south Texas, abnormal pressures are the province of the Vicksburg formation; the top of geopressure is frequently approximately coincident with the top of the Vicksburg. A notable exception is in the massive Frio delta near McAllen in Hidalgo County, where Frio deposition and active subsidence along the McAllen fault system were contemporaneous, and Frio sands occur to depths at least as great as $14,000 \mathrm{ft}$. The top of geopressure there is in the middle Frio.

The occurrence of abnormal pressure occurs at gradually increasing depth to the east; through central Cameron, eastern Willacy, and extreme eastern Kenedy Counties, geopressured Frio sediments occur to unknown depths. Where the Frio is greatly thickened near the coast, marine shale predominates, and sand buildup is generally poor.

\section{Temperature Regime}

In Live Oak County, temperatures above $300^{\circ} \mathrm{F}$ are restricted to Wilcox and deeper sediments. In the lower study region, temperatures of interest occur mainly in the Vicksburg formation and below. The geothermal gradient is highest in the west, generally declining to the east. Based on a limited number of control points, a $375^{\circ} \mathrm{F}$-geothermal surface was found to range from a depth of $14,000 \mathrm{ft}$ in southwestern Live Oak County to $22,000 \mathrm{ft}$ in eastern Kenedy County.

\section{Reservoir Parameters}

Examination of gas fields in the study region disclosed that the question of the deliverability of potential productive reservoirs is paramount, and that the critical parameter is formation permeability. Permeability of producing reservoirs throughout the region is indicated to be an inverse function of depth, and no effective permeability values as great as 10 md have been identified at depths which are associated with $300^{\circ} \mathrm{F}$ or higher temperatures.

In two widely separated fielas, each with a large number of separate producing horizons, the Ann-Mag field in the extreme north of Brooks County and McAllen-Pharr in the extreme south 
of Hidalgo County, permeability is shown to be highly dependent on depth, with a reduction of approximately one order of magnitude in permeability for each $2000 \mathrm{ft}$ of increased depth over the range of 6,000 to $14,000 \mathrm{ft}$.

The average permeability of lower south Texas gas fields at depths of 10,000 to 12,000 $\mathrm{ft}$ is $1 \mathrm{md}$ or less. In Live Oak County, the average permeability at this depth is somewhat higher but less uniform. The highest permeability value located in any reservoir with $300^{\circ} \mathrm{F}$ or higher temperature was $8.8 \mathrm{md}$ at $11,500 \mathrm{ft}$ in the East Tom Lyne (Wilcox) field, in Live Oak County.

Deep production throughout the lower south Texas study area has been largely confined to the Vicksburg formation, with the exception of the deep Frio delta in the McAllen-Edinburg area. Permeability values in the Oligocene are apparently primarily a function of depth rather than formation age. Frio sediments in the McAllen field are notably comparable in permeability to Vicksburg sediments at the same depth in northern Brooks and Kenedy Counties, even though the Frio sands are generally better developed.

\section{B. Conclusions}

Production of water from reservoirs similar to the south Texas gas reservoirs unquestionably cannot approach flow rates of $100,000 \cdot \mathrm{bbl} /$ day for sustained periods of time. While both Frio and Vicksburg formations include vertical intervals containing more than $500 \mathrm{ft}$ of sand, the permeability is too low to achieve high rates of flow.

Simultaneous production of extended intervals of sands at widely varying depths has not yet been attempted, and will be a prime requisite to successful exploitation of the geopressure-geothermal resource in south Texas.

Based on a minimum useful permeability of $1.0 \mathrm{md}$, water production at a temperature of $300^{\circ} \mathrm{F}$ is likely to represent an upper limit in south Texas reservoirs, with somewhat higher temperatures possible in Live Oak County.

Geopressure seems likely to originate in lenticular or highly faulted sand units deep in the Vicksburg, over most of the south Texas study region. Diffusion upward, particularly leakage along fault planes, tends to equalize the pressure over geologic time, resulting in the development of abnormal pressures in upper, larger sands which have become sealed during later periods. Thus high pressure aquifers of large extent may occur mainly near the top of the geopressured zone: Reservoirs such as the McAllen "8500" (Frio) sand, and the Vicksburg " $S$ " or " $T$ " sands in Jeffress field, relatively shallow and at unimpressive temperature, are likely to represent the best high-volume water prospects, with methane production as the principal goal.

High-temperature production $\left(>300^{\circ} \mathrm{F}\right)$ is most likely to be successful in Live Oak County because of the higher temperature gradient at depth, and the higher permeability of local deep Wilcox sands near the Mirando-Gohlke fault.

\section{Recommendations}

Specifically, the recommendations resulting from the study are as follows:

(1) Plans for implementation and demonstration of power plants based on south Texas geopressured water production should not be pursued. The low temperatures available indicate no 

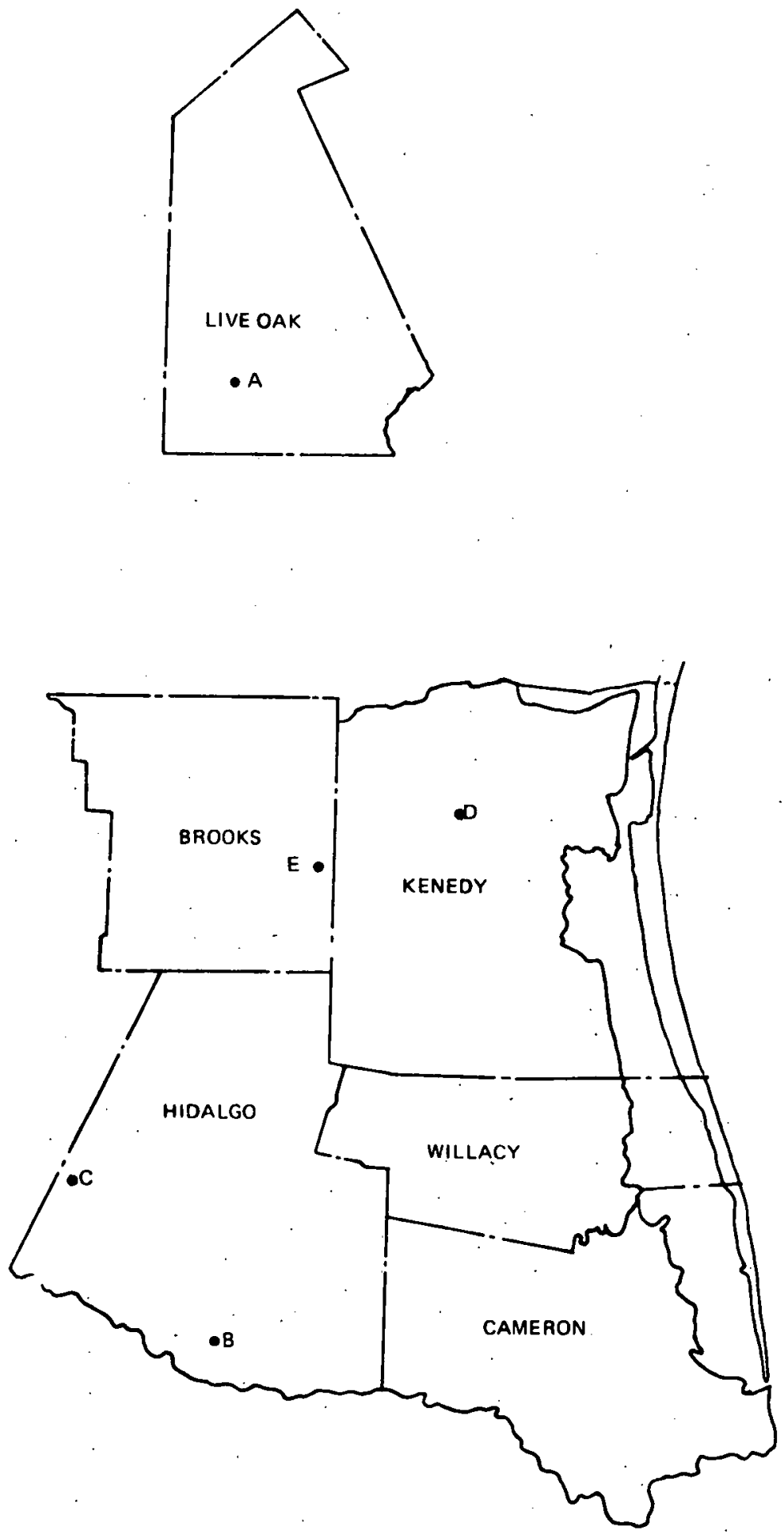

FIGURE 52. AREAS RECOMMENDED FOR FURTHER EVALUATION AND TESTING. (A) KATZ-SLICK AREA, LIVE OAK COUNTY:

(B) MCALLEN FAULT AREA, HIDALGO COUNTY; (C) JEFFRESS AREA, HIDALGO COUNTY; (D) CANDELARIA-SARITA AREA, KENEDY COUNTY; (E) VIBORAS AREA, BROOKS COUNTY economic success in exploitation of the available thermal energy for power purposes, until technology is greatly advanced in the use of low-temperature working fluids. Promising approaches to the latter should continue to receive support.

(2) In Texas, further assessment efforts at this time should be confined to a detailed search for permeable formations at depth. Generally speaking, Texas Gulf Coast reservoirs at depths below $10,000 \mathrm{ft}$ with permeability greater than $10 \mathrm{md}$ are rare, whether geopressured or not.

(3) Limited testing of certain selected areas in south Texas may be warranted, assuming useful information is acquired from tests now pending in Louisiana. These locations are marked on the map in Figure 52.

\section{a. Live Oak County.}

Flow tests to determine gas content at temperatures above $350^{\circ} \mathrm{F}$ are desirable, and Live Oak County appears to offer the greatest chance of success. A zone at $14,000 \mathrm{ft}$ in the deep Wilcox, to the northeast of the KatzSlick field, shows promise. A considerable body of professional opinion suggests there may be no gas at temperatures of $375^{\circ} \mathrm{F}$. This fact should be established as quickly as possible.

\section{b McAllen Fault Area.}

Enormous sand deposition occurs in the area immediately to the west of the McAllen field, adjacent to the McAllen fault. Here geopressured sands thousands of feet thick occur at every potential geothermal horizon and these should be explored from the top of geopressure to great depth. While there are few encouraging reservoir parameters in the producing field, it is possible that permeability may 
improve off-structure; if so, the tremendous thickness of the potentially productive section here could represent a favorable prospect.

c. Western Hidalgo County. In the Jeffress field area, blanket Vicksburg sands (the "S" and " $T$ " sands) occur at depths between 8,000 and 10,500 ft, and are apparently continuous over a reasonably large area. The depth is moderate, and the temperature gradient is the highest in Hidalgo County, with temperatures approaching $300^{\circ} \mathrm{F}$ at $10,000 \mathrm{ft}$. This is a promising place to attempt to produce a long vertical interval of low permeability sand, with a good chance of producing gassaturated water.

d. Northern Kenedy County. East of Candelaria field, Vicksburg sands at depths as great as $17,000 \mathrm{ft}$ have been logged. North of Candelaria, in El Paistle and E. Sarita Fields, Vicksburg sands produce gas to depths below $15,000 \mathrm{ft}$. Knowledge of the capability of these very deep south Texas sands to produce water is needed. The area should be more thoroughly evaluated, and these very deep sands explored and eventually tested.

e. Eastern Brooks County. The S.E. Viboras area, near the Kenedy-Brooks county line, lies along a large fault that separates it from the main Viboras field. Frio-Vicksburg sand buildup along the fault is excellent. Although control is limited, the aquifer, containing nearly $1000 \mathrm{ft}$ of sand from 9,800 to $12,300 \mathrm{ft}$, appears continuous off-structure along the fault to the north. Production of methane-saturated water from a long interval of clean, low permeability sand could be attempted here at relatively low cost. The temperature ranges from $220^{\circ}$ to $275^{\circ} \mathrm{F}$ over the section.

(4) Barring revolutionary developments in thermodynamics and heat engine design, the most favorable prospect for Gulf Coast geothermal water is in its direct, nonelectric uses. Suggestions for such use should continue to receive cautious evaluation. The application of hot water to leach-mining of Live Oak County uranium ore represents one such possibility. 


\section{BIBLIOGRAPHY}

Am. Assn. of Petroleum Geologists, "Geothermal Gradient Maps of the United States," AAP(; Geothermal Survey Committee, 1971.

Amyx, Bass \& Whiting, Reservoir Engineering, McGraw Hill, New York, 1960.

Bebout, D. G., "Subsurface Techniques for Locating and Evaluating Geopressured Geotherınal Reservoirs Along the Texas Gulf Coast," Proc. Second Geopressured-Geothermal Energy Conl., Austin, Texis, Feb. 23-25, 1976.

Boyd, D. R. and Dyer, B. F., "Frio Barrier Bar System of South Texas," Trans. Gulf Coast Assn. Geol. Soc., XIV, pp 309-322, 1965.

Collins, J. W., "The Geology of the McAllen-Pharr Field Area, Hidalgo Co., Tex." Trans. Giulf Cosast Assn. Geol. Soc., XVIII, 1968.

Dickinson, G. (February 1953): "Geologic Aspects of Abnormal Reservoir Pressures in Gull Coast Louisiana," Bull. AAPG 37, pp 410-432.

Dowdle, W. L. and Cobb, W. M., "Static Formation Temperature From Well Logs," J. Pet. Tech., XXVII, November 1975.

Fatt, 1., "The Effect of Overburden Pressure on Relative Permeability," Trans., AIME, 198, pp 325-326, 1953.

Fatt, I. and Davis, T. H., "The Reduction in Permeability With Overburden Pressure," Trans., AlMl:, 195, p 329, 1952.

Holt, B. and Bergman, J., "Investment and Operating Costs of Binary Cycle Geotlermal Power Plants," NSF Geothermal Conf. Proc., 1974.

Hottman, C. E. and Johnson, R. K., "Estimation of Formation Pressures Irom Log-Derived Sliale Properties," J. Pet. Tech. 234:6, pp 717-722, 1965.

Hottman, C. E., "Method for Producing a Source of Energy From an Over-Pressured Formation," U.S. Patent No. 3,258,069, June 1966.

Jones, P. H., "Hydrodynamics of Geopressure in the Northern Gulf of Mexico Basin," J. Pei. Tech.. pp 803-810, July 1969.

Joyner, H. D., "Correlation of E. Log Indicated Reservoir Temperature With Actual Reservoir Temperature," J. Pet. Tech., XXVII, February 1975.

Lewis, C. R. and Rose, S.C., "A Tlieory Relating High Temperatures and Overpressures," Soc. Pet. Eng., AIME, SPE 2564 Preprint, 8 p., 1. 19. 


\section{BIBLIOGRAPHY (Cont'd)}

Mattllews, C.. S. and Russcll, D. G., Pressure Buildup and Flow Tests in We'lls, Monograph Series, 1:48, Soc. Pel. Ling., AIME, Dallas, 1.967.

McLalchic, L. S., I lcmstock, R. A., and Young, J. W., "Eflective Compressibility of Rescrvorr Rocks and Its liflects on Permeability," Trans., AIME, 213, pp 386-388; 1958.

Nichols, F. A., "Geothermal Gradients in Mid-Continent and Gulf Coast Oil Fields," TP 2114 , Petrolcum Technology, 44-49, November 1946.

Osoba, J. S., Swanson, R. K., Oetking, P., and Hagens, R. C., "Production of Water from Geopressured(icothermal Rescrvoirs in South Texas," presented at Second Geopressure-Geothermal Energy Conf., Austin, Texas, 23-25 February 1976 (Southwest Res. Inst., San Antonio, 1976).

Parmigiano, J. M., "Geohydraulic Energy from Geopressured Aquifers," Thesis, Dept. of Petr. Engr., Louisiana State University, 1.973.

Schoeppel, R. J. and Gilarrani, S., "Use of Well Log Temperatures to Evaluate Regional Geothermal (iradients," J. Pet. Tech., 667-673, June 1966.

Sclmult\%, J. T., Jr., "Kat\%-Slick Ficld,"in Typical Oil \& Gas Fields of South Texas, Corpus Christi (icol. Soc. Pub., Corpus Christi, Texas, 1967.

Thomas, R. D. and Ward, D. C..." Effect of Overburden Pressure and Water Saturation on Gạs Permcilbility of Tight Sandstone Cores,": J. Pet. Tech., April 1972.

Vairogs, I., Hearn, C. L., Dareing, D. W. and Rhoades, V. W., "Effect of Rock Stress on Gas Production from Low:Permiability Reservoirs," J. Pet. Tech., pp 1161-1167, September 1971.

Willace, R. II., "Abnormal Pressures and Potential Geothermal Resources in the Rio Grande limbayment of Texas," Proc. Sec. Symp. on Abnormal Surface Pressure, pp 86-1 16, Baton Rouge; Lil., Louisiana State University.

Wilson, John S., et al., Dow Chemical Company; "A Study of a Phase "O". Plan for Production of liectricial Power From U.S. Gull Coast Geopressured Geothermal Waters," Proc: Sec. Geopressure(ieothermal Energy Conf., IV, February 23-25, 1976. 
APPENDIX A

Fields with Production Depths Deeper than 7000 Feet by County South Texas Study Area 
THE EOIINTIES FEOIIESTE[ AFE HILALIII

THE MINIMIM, MAXIMIIM EIEFTH FIEDIESTE[I IS ALL

THE LIWEF LIMIT IN YEAFi IS $1 \% A I L$

\begin{tabular}{|c|c|c|c|}
\hline FIELLI NAME & EDINTY & LIATE & LIEF'TH \\
\hline ALAMIISANLEF:S & HICIALEIII & AFFis 4 & $72 \geq 0$ \\
\hline ALAMII & HICIALGII & MAFi7 1 & 8065 \\
\hline AFIFIOIWHEA[I & HI IIAL.IIII & NIIVE.7 & 11942 \\
\hline EEAIIFL INEEAST & HIIIALIIII & $\Xi E F G=$ & $75 \div 1$ \\
\hline I:ANII-MEXIIII & HI [IALEII] & $B E F: 5$ & 7628 \\
\hline I:AF I SALLII & HI [IALEII & NIIV7 1 & 8039 \\
\hline DASAS: & HI [IALGII & MAYGS & 7031 \\
\hline CASASNIIFTH & HI [IALIII] & [IEI:65 & 7290 \\
\hline r:AS:AS:GIIITH & HI IIALIIII & FEE70 & 8744 \\
\hline CEREIIA & HI [IALIIII & [IEE: 62 & 9005 \\
\hline E:EFIIIA & HI IIALDiII & .IANG: & 10074 \\
\hline DEFILIA & HICIALIIII & SEFGS & 115.52 \\
\hline I:HIHIIAHIIA & HI [IALIIII & Al_115:5.5: & 5336 \\
\hline IIDNNAHANSEN & HI [IALIIII & .11_IL5: & 7478 \\
\hline [IIINNA & $H I[I A L[B]$ & [IEI: 6.5 & 7150 \\
\hline E[IINE:IIFili & HI [IALIIII] & IAN49 & 7563 \\
\hline EDINEIJFII & HI [IALIII] & Al11571 & 8993 \\
\hline E[IINEIIIFIIS & HI [IALIIII & MAY71 & 9755 \\
\hline E[IINEIIFIII & HI [IALIII] & MAFiGS & 10761 \\
\hline E[IINEIJFII; & HI [IALIEII] & $011: T 64$ & 11522 \\
\hline EUINBIJFIGEAST & HI IIALGII] & MAYSE & 7716 \\
\hline E[IINEILIFITIEAST & HI [IALIIII] & MUNEZZ & 6245 \\
\hline EDINEIIFIGEIIIITH & HI IALBIII & [IEE:S5: & 11104 \\
\hline ELSASOINITH & HIIIALGII & .11N71 & 7170 \\
\hline ELSEASIIIITH & HI [IALCiII & IANSEI & 5588 \\
\hline ELSASIOIITH & HI IIALIBII & NIVSS & 9774 \\
\hline FLIIFES: & HI [IALBiI] & NIIV70 & 8154 \\
\hline HAFIGILL & HI IIALISII] & FEE.5s & $100: 35$ \\
\hline HAFIGILL & HI IALIII & NIIVS4 & 11241 \\
\hline HEI I IELEEFIT; & HI [IALSIII & LIEC:70 & 8706 \\
\hline HI [IALIID] & HI [IALBII] & FEEBG: & $75: 30$ \\
\hline INDIOISWEST. & HI [IALEIIII & MAYES & 7413 \\
\hline JAVEL INA & HICIALISII & [11:T56 & 11174 \\
\hline . AAVEL INA & HI IIALIEII] & กI:T59 & 9800 \\
\hline JAVEL INA & HI[IALISII] & DILTSB & $10 \geq 57$ \\
\hline .JEFFFESSS & HI [IALCII] & LIELGS & 8690 \\
\hline IEFFRES: & HI IIALIIII] & SEFG & 7696 \\
\hline JEFFFES: & HILIALOIO & AFFiG: & 11318 \\
\hline JEFFFE $S:$ & HICIALIBII & EI:T70 & 12355 \\
\hline IEFFFESSEAST & HIDIALEIO & IAN7 1 & 12430 \\
\hline KELSEYEAST & HI IIALGOI & SEFS\% & 11972 \\
\hline FLIIMF & HILIALEII & FEES: & 6754 \\
\hline LAELANE:A & HI IALEII] & O11:T:36 & 8175 \\
\hline LAEILANI:A & HI LIALCIII & IAN71 & 7839 \\
\hline LAELANI:A & HILIALGIO & .IAN 59 & 7450 \\
\hline
\end{tabular}




\begin{tabular}{|c|c|c|c|}
\hline LAELANE:A & HIIIALIIII] & $. J A N=4$ & 9001 \\
\hline LAEILANI:A & HI IIALIEII] & .JAN 64 & \\
\hline LAELANI:A & HI IIALIBI] & .JANE.4 & 1008 \\
\hline LALDIMA & HI IIALBII] & .111L5: & \\
\hline LA._IAF'A & HI [IALIOI] & - IANEZ & \\
\hline LA._IAF:A & HI IIALEII] & FEE5 4 & $100 \leqslant$ \\
\hline LAFIEFDF'MA & HI IIALCIOI & FEE: $6::$ & \\
\hline LAEY & HILI-I:AMEF & [IEE: 46 & \\
\hline LAE:Y & HILIALISIO & .1111449 & 71 \\
\hline LANCIA & HI[IALIEIII & JANBO & \\
\hline LANEIA & HI[IALIII.]. & [IEE:S: & 52 \\
\hline LEISINCIIIS: & HIIIALIIII & $.1111<47$ & 844 \\
\hline LOSINLI I IS: & HICIALEIII & EEF:47 & 711 \\
\hline LESINLIIS: & HI IIALIEII & {$[11: T \leqslant 0$} & 1009 \\
\hline L.DSINLI I ISWEST & HI [IALIEII] & - IIIN7O & 707 \\
\hline LIISTOFF I TIS: & HI IIALIEIII &. $\mid$ AN. 1 & 851 \\
\hline LOSTGRFI I TES & HICIALEIII &.$I A N G 9$ & \\
\hline LOSTOFF I TDSNIIF: & HICIALIEIII & FEE:56 & 515 \\
\hline MEALLLEN & HI [IALEII] & IU:T:E & 706 \\
\hline MI:ALLEN. & HI LIALGIO & DI:T:JE & $8: 10$ \\
\hline MIE:ALLEN & HI LIALITIII & חI:T:S̈E: & 1007 \\
\hline MIEALLEN & HI [IALIBI] & AFFiE:S & 1146 \\
\hline MC:ALLEN & HI LIALGID & Alliss.5 & 958 \\
\hline ME:ALLENSIIUTH & HI IIALGOI & $.111 L 65$ & $74: 3$ \\
\hline ME:ALLENEIOUITH & HIDALGO & 111ا_L.5.5 & 842 \\
\hline MI:ALLENGIIITH & HIDALGID & [III:TES & 985 \\
\hline MI:ALLEENEIIITH & HIIIALIII] & MAFi $=4$ & 1023 \\
\hline MI:ALLENWEST & HI IIALEIII & FEEGO & 70 \\
\hline ME:ALLENWEST & HI IIALIIII) & Al_IIEG & 82 \\
\hline MEALLENRANIEH & HI [IALEID & ALII:B7 & 72 \\
\hline MI:ALLENFIANI:H & HILIALOIO & NIEVE 4 & 1011 \\
\hline ME:ALLENFANI:H & HI IIALDIO & $A F \cdot F B=1$ & 110 \\
\hline MI:ALLENFANI:H & HI IIALOID & MARE 6 & $13: 7$ \\
\hline MI:ALLENFANE:H, & HI IIALEIO & SEFBS & 1235 \\
\hline ME:OUIELAST & HIDALEIO & AFFIO & $121 E$ \\
\hline MEMIIFAN & HI [IALEID & FEESG & 82 \\
\hline MEMIIAN & HILIALIII & -IIINSE: & 82 \\
\hline MEFIL:ELIE: & HI IIALIIII & AFF:S & 74 \\
\hline MERL:ELIES & HI LIALISIO & . Jال & 90 \\
\hline MEFIC:E[IE: & HICIALGIO & NIIVS? & 101 \\
\hline MERILELIESSW & HILIALGIO & MAFiB & $9: 3$ \\
\hline MEFILEDESSWW & HI LIALIII] & .IILLES & 10.59 \\
\hline MISSI INWWEST & HILIALEII] & MAF:5: & 71 \\
\hline MISGI INUWEST & HIDALEOIO & JUIN5.5 & 825 \\
\hline MIINTEI:HFI ISTO & HI LIALGII & MARSO & 726 \\
\hline MONTELHFISITO & HI IIALEIII & -IIIINS: & 8478 \\
\hline MONTEI:HF: I STO & HI IIALEII & Alllis: & 10064 \\
\hline MONTEILHFI I ETO & HI [IALIII] & DIELBO & 11283 \\
\hline MINTEE:HFIISTUE & HI IIALIEIII & [IEI:S: & 966 \\
\hline MINTEI:HF:ISTOH & HI [IALIBI] &. IAN54 & 532 \\
\hline MINTEI:HFI ISTIN & HI [IALIEII] & .11_IL64 & $\$ 41$ \\
\hline MIINTEE:HFI ISTLE & HI [IALEII] & -IIIINE 1 & 779 \\
\hline MIINTELHFISTIIS & HIDALIEI & AlJIS60 & 542 \\
\hline MINNTEI:HFI I GTIS & HITIALEII & AFF'b 1 & 1051 \\
\hline
\end{tabular}




\begin{tabular}{|c|c|c|c|}
\hline DELATE & HI LALLII & DE:T50 & 7390 \\
\hline MELATE & HICIALEIII & FEE:61 & $11: 317$ \\
\hline F'ENITAS & HI [IALISI] & $\Xi E F @ 7$ & 7534 \\
\hline FENITAS & HI [IALLII] & Al_l1559 & 8276 \\
\hline FHAF'K & HILIALIII] & $\cdot 11 / L 49$ & 9370 \\
\hline PHAFiFi & HILALEII] & . & 8657 \\
\hline F'HAFiFi & HI LIALCIO & 49 4الالـ. & 10650 \\
\hline PHAFiFi & HI LIALISII] & Alli_is: & 15766 \\
\hline FHAFIR' & HIDALDII & ALIISB & 11575 \\
\hline FFIIISRESSII & HI LIALBDII & MAYBI & $8: 548$ \\
\hline RETAMA & HI IIALGII & FEEST 7 & 7769 \\
\hline FIIIO & HITIALEII & -IANES & 7120 \\
\hline SALLIELFEYY & HILIALIII & MAYSS & $\Xi 178$ \\
\hline SALIIELFEYWEST & HI IIALBOI & IIIN 60 & 8138 \\
\hline SALEIELFEYWEST & HILIALIBII & Al 1557 & 9189 \\
\hline SANI:AFLLOS & HI IIALDID & [IEL: 64 & 7264 \\
\hline SANE:AFLLI:E & HI TIALLIII & [IEL:5:3 & 5790 \\
\hline SANMANI_IELL: & HI DIALIEO & MAYEIZ & 7598 \\
\hline SANMANIIEL & HICIALGOI & MAYB 1 & 8265 \\
\hline SANFAMIIN & HILIALIOI] & iIIL.57 & $84: 3$ \\
\hline SANFIAMIIN & HI IIALIOII] & . IIIL $\leqslant 1$ & 11005 \\
\hline SANSALVALIÖR & HI DALISII & [II:T64 & 7224 \\
\hline SANSALVA[HEF & HI IIALIIII & MAY47 & 8104 \\
\hline SANEALVALIIIF & HI IIALIOI] & FEE:70 & 9155 \\
\hline BANSAL VALIIIF & HI LIALISID & FEETO & $10: 360$ \\
\hline SANTAANITA & HIDALISO & NCIVEA & 9380 \\
\hline SANTAANITA & HITIALEIT & NDUGZ & 11624 \\
\hline SANTAFESOIITH & HIT-EFO & NDV4\% & 7722 \\
\hline SANTAFESOILITH & HI LIALEOO & AlJIS60 & 7185 \\
\hline SANTAMAEI IA & HI IIALGII & {$[I E[: 5 \%$} & 8339 \\
\hline SANTELLANA & HILIALLID & FEE:70 & 7006 \\
\hline SANTELLANA & HI IAALEID & NIIV7O & 8012 \\
\hline SCHMIIT & HILALEII & AFFIS: & 8572 \\
\hline SHAFIY & HIDIALEIO & $.1111<.52$ & 8172 \\
\hline SHAF'Y & HICIALEIO & [IEI:56 & 7217 \\
\hline GHEFHERI & HI LIALBDI & SEF'5 & 7019 \\
\hline SHEFHERCI: & HICIALISI] & AlULEZ & 7012 \\
\hline TAE:AS:0:0 & HI IIALISI] & . IUN55 & 7935 \\
\hline TAE:AEC:O & HILIALEIO & $A F R 5 B$ & 8114 \\
\hline TAEASIONOFTH & HI IIALBII & AUJiso & 7790 \\
\hline TEXANGAFIENS: & HILIALEII & SEF'Ъ & $7: 394$ \\
\hline TEXANGIAFILENS & HILIALIIII & .IINES & 8020 \\
\hline TEXANGIAFILIENS & HILIALEIO & FEES64 & 9262 \\
\hline TQLIISEANTIS & HI LIALISO] & [IEL:64 & 10686 \\
\hline WESLAC:INGRTH & HILIALEIO & $A F \cdot 5 \%$ & 8299 \\
\hline WESLALINOFTH & HI LIALED] & MAY $E 0$ & 9056 \\
\hline WESLACIINOITH & HIDALEOI & MAYSF & $10 \geq 42$ \\
\hline WESLAC:DSDIUTH & HIDALEOI & Al_Lib: & 75.32 \\
\hline WESLACOSEIITH & HICIALEII & FEE:45 & 8090 \\
\hline WESILAIEOSIIITH & HIDALIIII & EIETSZ & 9020 \\
\hline WHITTE[I & HI IIALEID & FEEGO & 7113 \\
\hline
\end{tabular}


THE COINTIES FEDIIESTE[ AFE HILALGO

THE MINIMIIM, MAXIMUIM [IEFTH FEEIIESTED IS 10000, 20000

THE LOWEF LIMIT DN YEAFi IS $19 A L L$

\begin{tabular}{|c|c|c|c|}
\hline FIEL.I NAME. & EOIINTY & [IATE & DEF'TH \\
\hline AF:FIIWHEA[I & HI [IALEIII & NIIUSB & 1194 \\
\hline CEEFICIA & HICIALGO & -IANB: & 10074 \\
\hline EEFILIA & HILIALIOIOI & EEF@S & 115.52 \\
\hline E[IINE:I_IFII_ & HICIALDIO & MAFi 6.5 & 10761 \\
\hline E[IINEIUFII & HILIALISI & UI:TE4 & 11522 \\
\hline E[IINE:IRIGSGIITH & HILALGOI & DEE: 6.5 & 11104 \\
\hline HAFIGILL & HI IIALIOII & FEE:SE & 100.3 .5 \\
\hline HAFIEILL & HILIALIEO & NIIVSI & $11 \geq 41$ \\
\hline .IAVEL INA & HICIALEOID & 이:T5s. & 11174 \\
\hline -IAVEL INA & HICIALEOI & III:T6: & 10257 \\
\hline -JEFFFIE: & HILIALLOO & $A F R=9$ & 11318 \\
\hline -IEFFFES: & HI DIALEIII & 其 & $12: 35$ \\
\hline JEFFFESEEAST & HILIALGII & IAN7 1 & 12430 \\
\hline КELSEYEAST & HILIALGIO & $S E F$ & 11972 \\
\hline LAELANEA & HI [IALEOI & JANB4 & 10082 \\
\hline LA.JAF:A & HI DALCOII & FEE:S4 4 & 10064 \\
\hline LOBINUIIOS & HI [IALEII] & EII:T 60 & 10071 \\
\hline MI:ALLEN & HILALIOI & 口II:T:BE & 10090 \\
\hline ME:ALLEN & HI DAALEIO & AFFis: & 11464 \\
\hline MI:ALLENSIIITH & HI [IALEII & $M A F i \leqq 4$ & 10239 \\
\hline MI:ALLENFANI:H & HIDALIBO & NIIVE4 4 & 10117 \\
\hline MI:ALLENFIANIEH & HIDIALEO & $A F \cdot F: B=1$ & $110 \mathrm{st}$ \\
\hline ME:ALLENFIANE:H & HI LIALEOI & MAFISE & 13076 \\
\hline MI:ALLENFANE:H & HI [IALISI] & SEFOS & 12356 \\
\hline MELCOHKEAST & HI LALGO & $A F F=0$ & $1 \geq 181$ \\
\hline MEFIE:ELIE: & HIDALDO & NGIVS耳 & 10144 \\
\hline MEFICEDIESSW & HIDALEIO & $.111 L G 6$. & 10594 \\
\hline MIINTEI:HFI ISTO & HI DIALGOD & Al_IISB & 10064 \\
\hline MENTEEHFISSTI & HIDALEOI & [IEE:SO & 11283 \\
\hline MINTEEIHFI ISTIS & HI LIALBO & $A F^{\prime} F=1$ & 10515 \\
\hline IELATE & HITIALGO & FEE 61 & 11317 \\
\hline F'HAFIF & HIDIALOO & . IIIL 49 & 10650 \\
\hline PHAF'F: & HI IIALEID & Al]1565 & $1: 3766$ \\
\hline FHAFIF: & HI IIALIBO & AllISB: & 11975 \\
\hline SANFIAMIIN & HI IIALEO] & . JIL_S1 & 11005 \\
\hline SANSALVALIOF & HI IIALEOI & FEE70 & 10350 \\
\hline SANTAANITA & HI IIALGII] & NIOUSZ & 11624 \\
\hline TOLUESEANTDS & HICIALEO & [IEI:64 & 106.56 \\
\hline WESLACIINGFTH & HI [IALEII & MAY5Y & $10 \geq 42$ \\
\hline
\end{tabular}


THE EDINTIES FEDIIESTELI AFE EAMEFIOIN

THE MINIMIIM, MAXIMIIM LIEFTH FEEULESTELIS ALL

THE LOWEF LIMIT INN YEAF IS $19 A L L$

\begin{tabular}{|c|c|c|c|}
\hline FIELII NAME & EIINTY & LIATE & CIEF'TH \\
\hline HILLLYEEAI:H & I:AMERIIN & AF'FE: & $71:$ \\
\hline HIILL.YEEAE:H & I:AMEFIIN & $A F F i=4$ & 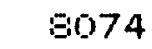 \\
\hline INIIIIS & E:AMEFIOIN & $.11 .1 N 57$ & 97 \\
\hline L.AL:Y & E:AME'FIIN & EEF.56 & 7 \\
\hline FIOFT I SAEELWW & I:AMEFIIIN & MAFIES & 70 \\
\hline FIOFT I SAEELW & I:AMEFIIIN & FEE: $\leqslant 4$ & 81 \\
\hline SANMAFIT IN & I:AMEFIIIN & MAF'S: & 8 \\
\hline SANMAF:TIN & E:AMEFIIN & MAFi65 & \\
\hline THFEE I SLANIISEA & I:AMEFIIIN & $.111 L 59$ & \\
\hline VI :TALIEL.MAFi & C:AMERIIN & $.111 \operatorname{LL} 67$ & 70 \\
\hline
\end{tabular}


THE COINTIES FEOUIJSTE[ ARE WILLAC:Y

THE MINIMIIM, MAXIMUM DEFTH FEQIJESTELI IS ALL

THE LOWEF LIMIT DNN YEAF: IS $19 A L L$

\begin{tabular}{|c|c|c|c|}
\hline FIELII NAME & EOINTTY & LIATE & LEF'TH \\
\hline I:HES:S & WILLAI:Y & MAFIGB & 7014 \\
\hline EHE:S: & WILLAE:Y & MAF:56 & 8518 \\
\hline DOIFIEETTMAFI INE & WILLACY & NOVSE & 9766 \\
\hline LABALVIE,IA & WILIACEY & MAY 47 & 7010 \\
\hline LASALVIE,IA & WILLAI:Y & AUIG4\% & 8290 \\
\hline LASALVIE.IA & WILLACY & NOUVEZ & 10546 \\
\hline LASALVIE.JA & WILLAI:Y & OI:T45 & 9735 \\
\hline LASAFIAEAST & WILLAEYY & -IAN71 & 7486 \\
\hline LASAFAAEAST & WILLAE:Y & SEF 67 & 8229 \\
\hline LASAFANOFITH & WILLAI:Y & $.1 A N \leq 7$ & 7867 \\
\hline LAI:AL & WILLAI:Y & NINUSS & 7550 \\
\hline LAC:AL & WILLAEY & NINES & 8226 \\
\hline LYFIERII & WILLAE:Y & FEE:G & 9046 \\
\hline NILE & WILLAI:Y & IIIL67 & 10144 \\
\hline FASIOKEAL & WILLAI:Y & Alulises & 7138 \\
\hline FASICIREAL & WILLACY & NOU4S & 8585 \\
\hline FAYMIINEIVILLE & WILLAEYY & JAN45 & 96.50 \\
\hline FAYMONIU ILLE & WILLAC:Y & .JANBS & 7004 \\
\hline FAYMMINEIVILLE & WILLACYY & FEEGO & 8034 \\
\hline RAAYMONLIU ILLESOO & WILLAC:Y & SEFBS & 7448 \\
\hline RIIIEAN & WILLAE:Y & FEESB & 8.511 \\
\hline RIIIEAN & WILLAEY & FEEG & 9772 \\
\hline TENERI IAS: & WILLAI:Y & AF'F: $:$ & 7947 \\
\hline WILLAMAFi & WILLAC:Y & NiIV40 & 7574 \\
\hline WILLAMAF:SIIIITH & WILLAEY & SEF:S4 & 8006 \\
\hline WILLAMAFSIIUTH & WILLAE:Y & MAYE7 & 7897 \\
\hline WILLAMAFEEE & WILLAC:Y & IIILSSS & 7851 \\
\hline WILLAMAFWEST & WILLAE:Y & MAF41 & 7925 \\
\hline
\end{tabular}


THE COUNTIES FEOIIESTEL AfIE KENELYY

THE. MINIMIIM, MAXIMIIM LEFTH FEEQIIESTELIS ALL

THE LOWEF: LIMIT DNN YEAF I: $1 \% A L L$

\begin{tabular}{|c|c|c|c|}
\hline FIELLI NAME & EIIINTY & [IATE & DEF'TH \\
\hline EAFF INEAY & KENELIY & MAFiE.7 & 13076 \\
\hline EAFF INE:AY & KENEIIY & Allitists. & 12001 \\
\hline E:AFF INE:AY:SW & KENE[IY & 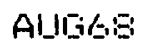 & 12283 \\
\hline EAFFETA & YENED'Y & {$[I E[: 54$} & 7150 \\
\hline E:AFIFETA & FENE[IY & $\Xi E F 54$ & 9121 \\
\hline CAE:AZDIE & KENE[IY, & MAFE 9 & 7400 \\
\hline CAEAZIIE: & KENE[IY & FEEGS & 8040 \\
\hline E:ALANEIFI I A & KENE[IY & FEE:- & $0: 674$ \\
\hline EALANEIFI I & KENEDYY & FEE:I & 8675 \\
\hline EANLELAFIIA & KENE[Y & $\Xi E F: 4$ & 11190 \\
\hline I:ANLIELAFIIA & KENE[IY & MAFi:SG & 7028 \\
\hline E:ANLIELAFIA & KENE[IY & $A F^{\prime} F^{\prime}=4$ & 8094 \\
\hline IAANLIELAFI IA & KENERIY & AldIE & 7558 \\
\hline EANEIELAFIIA & KENEDY & [IEI:G: & 10075 \\
\hline EL.FAISTLE. & KENE[IY & $.111 L \leqslant 4$ & 14427 \\
\hline ELFAISTLE & KENE[IY & EEFG? & 1989 \\
\hline ELF'AISTLE & KENEIIY & .111651 & 7057 \\
\hline ELF'AISTLE. & KENERY & IANE:3 & 908 \\
\hline ELFAISTLE. & KENEDYY & -IANSZ & 8280 \\
\hline EL.FAISTLE & KENE[IY & MAY $=7$ & 11522 \\
\hline . IIIL I AN & KENE[IY & EH:TE: & 894 \\
\hline .HIL I ANNIIFTH & KENERYY & NIUESE & 997 \\
\hline LAr_IIINA & KENEIIY & AlliI: 54 & 9404 \\
\hline MAYSIIIITH & FENE[IY & [IE $[:: 0$ & 757 \\
\hline MC:IEILL & KENE[IY & FEE 47 & 767 \\
\hline MI:SGILL & KENELIY & .IIING: & 813 \\
\hline MEII I LL. & KENERYY & [IEE: 64 & 9704 \\
\hline MI:İILLSWW & KENEDIY & . $-11 N 71$ & 7707 \\
\hline MESIOIIITE & KENELIY & $A F F=5$ & 785 \\
\hline MESIDIIITE. & KENELIY & [IEL:CI: & 827 \\
\hline MIFFLIN & KENELIY & ВI:TG: & 768 \\
\hline MIFFLIN & KENE[IY & MAY 54 & $9: 3$ \\
\hline MONTEFASTIIRE & KENE[IY & $A F F i E 1$ & 755 \\
\hline MONTEFASTIIFE & KENE[IY & AF'R'S\% & 921 \\
\hline MIIFIICII:KFASS & KENE[IY & [IEI:LI: & $72: 3$ \\
\hline MIJFIIIIIEKFAS:SEST & KENE[IY & FEE:G, & 75.5 \\
\hline MIIFIIIIEKFASSEST & KENE[IY & .IIINE.5: & 800 \\
\hline MIJFILIR_YFASESST & KENEDYY & FEE:G: 7 & $7 \geq 7$ \\
\hline PENA:II:AL & KENE[IY & FEE:LZ & $70: 3$ \\
\hline FITAEAST & KENEDIY & MAFi71 & 850 \\
\hline FOTRERT & KENE[IY & . $111 L .5$ & 946 \\
\hline FITTFEFIO & KENEIIY & .11_IN 13.5 & 745 \\
\hline FOTFEERIDEIIIITH & KENELIY & [IEC:6: & 743 \\
\hline FITA & KENEIIY & JAN49 & \\
\hline FITA & KENEDY & -IAN4: & 805 \\
\hline
\end{tabular}




\begin{tabular}{|c|c|c|c|}
\hline FIITA & RENE[IY & Al $11 ; \leqslant 4$ & 12898 \\
\hline FITA & KENE[IY & INES & $\$ 017$ \\
\hline $\begin{array}{l}\text { FI TASE } \\
\text { RITASE }\end{array}$ & $\begin{array}{l}\text { FENELIY } \\
\text { KENELIY }\end{array}$ & $\begin{array}{l}\text { [IEE:70 } \\
\text { MAY } 64\end{array}$ & \\
\hline FI I TAWE & KENE[IY & [IEL:G:3 & 84.5 \\
\hline FIUIIIILFH & FENE[IY & AF'RitE & 79 \\
\hline FIIIULLFH & FENETIY & AFFigE. & 51 \\
\hline SALTILLD & KENE[IY & UIL 67 & $\because$ \\
\hline SANTAFIIISA & KENETIY & - IINES: & 106 \\
\hline SARI I TA & KEN-KLE & MAY $4:$ & 71 \\
\hline SAFITA & KENE[IY & Al_11567 & 70 \\
\hline SAFITA & FENE[IY & NDVG4 & 80 \\
\hline SAFI I TA & KENE[IY & AF'FiG.5 & 92 \\
\hline SARITA & FENEIIY & . IIIL_64 & 12 \\
\hline SAFIITA & FENE[IY & SEF $6 Z$ & 1019 \\
\hline SAR I TAEAST & KENE[IY & JULLS7 & 1310 \\
\hline SOFILLE & FENE[IY & FEE $6 B$ & 1154 \\
\hline STILLMAN & KENE[IY & MAY7 1 & $\Xi 4$ \\
\hline ST ILLMAN & KENE[IY & [IE]: 6.4 & 700 \\
\hline ST ILLMAN & KENE[IY & . & 805 \\
\hline ST ILLMAN & FENE[IY & ALIISBS & 920 \\
\hline ST ILLMAN & KENE[IY & MAY7 1 & 1015 \\
\hline ST ILLMAN & KENE[IY & -JANGS & 1102 \\
\hline ST ILLMAN & KENE[IY & FEEGB & $125=$ \\
\hline TA.JIIS: & IENELIY & $0 \mathrm{C}: T \leqslant 4$ & 821 \\
\hline TOFIIILLA & KENE[IY & DCTES & 1046 \\
\hline
\end{tabular}


THE DIIINTIES FEDUIESTED AFE FENE[Y

THE MINIMIIM, MAXIMIJM [IEFTH FEEIIESTEI IS 10000,20000

THE LIIWEF LIMIT IIN YEAF IS $19 A L L$

\begin{tabular}{|c|c|c|c|}
\hline FIELII NAME & EIIUNTY & [IATE & [IEF'TH \\
\hline EAFF INEAY & KENE[IY & MAFiE 7 & 13076 \\
\hline EAFF INEAY & FENE[IY & Al_ligs & $12: 01$ \\
\hline EAFF INEAY:WW & IENE[IY & Allib: & 12283 \\
\hline CANDELAFIA & KENE[IY & $5 E F 54$ & 11190 \\
\hline CANDELAFIA & KENE[IY & [IELE: & 10075 \\
\hline ELFAI STLE & KENE[IY & .11L 64 & 14427 \\
\hline ELFAI STLE & KENE[IY & SEFڤS & 1:30:55 \\
\hline ELPAI $\Xi T L E$ & KENEEIY & MAYG7 & 11522 \\
\hline FIITA & FENE[IY & Al_list.4 & 12898 \\
\hline FIITASE & FENE[IY & [IEE:70 & 11983 \\
\hline FITASE & KENE[IY & MAYE 4 & 13100 \\
\hline SANTARIISA & FENE[IY & JINES & 10660 \\
\hline SAFIITA & KENE[IY & .JIL 64 & 12195 \\
\hline SAFIITA & KENEIIY & SEF 62 & 10190 \\
\hline SARI TAEAST & KENE[IY & . IIIL 67 & $1: 3108$ \\
\hline SOFi ILLO & KENE[IY & FEEB: & 11546 \\
\hline ST ILLMAN & KENERIY & MAY71 & 10156 \\
\hline ET ILLMAN & KENE[IY & JANBG & 11028 \\
\hline ST ILLMAN & KENE[IY & FEEES: & $125: 30$ \\
\hline TOIRDILLA & FENEOIY & OCT6 & $104 \leqslant 4$ \\
\hline
\end{tabular}


THE COLNTIES REOUJESTEI AFE EFIOUKS

THE MINIMIIM, MAXIMIIM LIEF'TH REOUESTED IS ALL

THE LOWEF LIMIT ON YEAF̈ IS 1 GALL

\begin{tabular}{|c|c|c|c|}
\hline IELII NAME & EOUNTY & DATE & DEFTH \\
\hline ALTAMESA & ERCIOKS & - MLLEZ & $77 \leqq 7$ \\
\hline ANNMAI; & BFGUKS: & MAYGZ & 9117 \\
\hline ANNMAI: & ERIOCLS & GC:TB: & 7004 \\
\hline ANNMAG; & EROIOLS & SEFGZ & 8220 \\
\hline ANNMADSSOIITH & ERTILSS & SEFBS & 7152 \\
\hline CAC_EFIANE:H & ERIOIKS: & AFRE & 7813 \\
\hline CACEEFIANIEH & E:RCIDICS & MAY4S & 8022 \\
\hline :ARIEFIANE:H & ERIIIKS & ALIT,59 & 7804 \\
\hline CARIEFIANCHNIIFTH & GRIUIKSS & [II:T6: & 8755 \\
\hline HAMEEFLAIN & EROIITS & لـالـ. & 7806 \\
\hline IANSIULL IVAN & 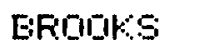 & Al_ & 8508 \\
\hline IANGIILLL IVAN & 65 & 44 & 10155 \\
\hline DANSIILLI I VAN & 6 & SEF 45 & 7831 \\
\hline EFFFFIII & & 69 & 68 \\
\hline ENI:INITAS & $k 5$ & $\$ 0$ & $8 \angle 66$ \\
\hline ENEINITAS & 165 & & 7054 \\
\hline ENE:INITAS & $\mathrm{S}$ & $A F$ & 7338 \\
\hline ENE: IN I TASEAST & 65 & 70 & 9731 \\
\hline ENIE: INITASNW & 65 & MAYB 7 & 7596 \\
\hline ENEINITA: & 6 & $A F^{\prime} F$ & 10212 \\
\hline ENEINITASSOILITH & EF & SEF'B 4 & $10: 12$ \\
\hline ENCINITASWEST & EF: & NOUBS & 10707 \\
\hline ALFIJRF I AS & ERGIITS & AlIIjBS & 7254 \\
\hline FLIIWELLA & E:ROIIKS & MAY45 & 7238 \\
\hline GYFHILL & 165 & NIIV5.S & 7425 \\
\hline GYFHILLSE & EFICHIKS & NGIVE.7 & 7430 \\
\hline BYYFHILLSE & EFIODKS & . & 8330 \\
\hline KELSEYIEEF & EFTIIIKS & JANES & $7: 280$ \\
\hline KELSEY[IEEF & EFIIIIKS & 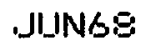 & 8078 \\
\hline YELSEY[IEEF & EFIOIDKS & FEBB 7 & 7620 \\
\hline KELSEYIIEEF & ERIIIKS: & FEESG & 9023 \\
\hline KELEEY:SE & EIFIOIOLS: & MAY71 & 7789 \\
\hline KELSEYSE & GRIOIOHS & MAY7 1 & $\$ 175$ \\
\hline KELSEYSE & ERODIVIS & $S E F G 4$ & 8953 \\
\hline KELSEYSE & EFIOIRES & $S E F E 4$ & 10312 \\
\hline LAENI:ANTADIA & EFIODKS & [IEDE. 3 & 8786 \\
\hline LAENI:ANTALAES:T & E:R'DIOLS: & NIIUSS & 8603 \\
\hline LASGLORIA & EFIDIIKS & SEF'48 & 7123 \\
\hline LAIILOEFIA & EFIDIDLS & FEE 6.5 & 8220 \\
\hline LACILIIFI IA & EARIDIKS & MAYB4. & 7870 \\
\hline AlILLOFI IA & EEFIIILES & [IEI:-64 4 & 7860 \\
\hline _ADILOFI IASOUUTH & [:Fi]-.IIMW & MAF.5.5 & 7270 \\
\hline AGLLE: I ASOOUITH & EFi[UII)S & $.111 N 6.5$ & 7.596 \\
\hline LIMAEELANE:A & ERIIILNE & MAY 63 & 7053 \\
\hline LIMAELANI:A & ERIIITSS & [IEI:SZ & 8979 \\
\hline
\end{tabular}




\begin{tabular}{|c|c|c|c|}
\hline $\begin{array}{l}\text { LIMAELANEA } \\
\text { MAFI IFUISA } \\
\text { MAFI IFUSA }\end{array}$ & 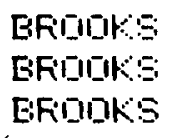 & $\begin{array}{l}\text { CIEL:E: } \\
\text { AFF } 45 \\
\text { IAN49 }\end{array}$ & $\begin{array}{l}9415 \\
9037 \\
7781\end{array}$ \\
\hline MAFIIFUSA & ERIIILAS: & MAR:54 & $\$ 524$ \\
\hline MIEHELSIIN & EFIDUKS: & $\because$ IANG 4 & 7702 \\
\hline MIEHELSON & EFIIIDYS & [IE]:6:3 & 5541 \\
\hline FITA & EFIIIISE & MAF 4乡 & 7112 \\
\hline FITA & ERIIIIT:S & AF'F:47 & 8004 \\
\hline FITAEAST & ERIOIKS: & AlILE $E 1$ & $775:$ \\
\hline PITAWEST & EFIDIIKS: & [II:T64 & 7516 \\
\hline PITAWEST & EFIIIIKS: & UIIL69 & $80 \geq 5$ \\
\hline FITAWEST & EFIIUIKE & EEF'G1 & 9050 \\
\hline FAL:HAL & EFIOUIKE: & {$[110: T \leqslant 4$} & 90.58 \\
\hline SANTAFE & BFIOILKS: & .IAN49 & 771.5 \\
\hline SANTAFEEAST & EFIOULKS & Al_II: 64 & G688 \\
\hline SANTAFESIDIITH & EFIIIIKS: & 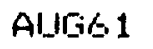 & 7621 \\
\hline SCIOTT $/ H I F F E F$ & E:FIIIIIKS: & Al_II;46. & 7024 \\
\hline SCOITT/HDFF'ER & EFIOICIKS: & IANG7 & 8141 \\
\hline SCOTT/HIFFERES & EFIOIOKS & FEESG4 & 10287 \\
\hline SKIF'F'ER & EFIIIIKS: & $-111 N 6.5$ & 8224 \\
\hline SKIF'FER & EFIDIKE: & NIDUG 4 & 9058 \\
\hline TRESENIE: INCIS & BFEIIIKS & MAYEZ & 725 \\
\hline VIECIRAS: & EFIOIKS & AlJī 49 & 8110 \\
\hline VIEOREAS & E:F'DIIIKS & Al_II;49 & 7925 \\
\hline VIEOFAS & EFIOIKS: & NIIVES & 922 \\
\hline VIEOIFAS & EFIIIIK: & FEEG7 & 1154 \\
\hline VI BORASSE & EFIIIIKS: & DI:TS3 & 1210 \\
\hline VIEOIFASWEST & E:FIIIKS: & FEG.53 & 708 \\
\hline VIECRASWEST & EFIIIIKS & AFRBI & 835 \\
\hline
\end{tabular}


THE COILNTIES FEDIIESTED AFE ERIOGKS

THE MINIMIIM, MAXIMIIM [IEPTH REDIJESTE[I IS 10000,20000

THE LOWEF LIMIT ON YEAF IS $19 \mathrm{ALL}$

\begin{tabular}{|c|c|c|c|}
\hline FIELE NAME & EIIINTY & LIATE & DEFTH \\
\hline IIANEIILL I VAN & EFIOIOKS: & Al.1T;44 & 10155 \\
\hline ENC INITASEE & ERIOIKS: & APFi70 & $10 \pm 12$ \\
\hline ENE: INI TASSIIIITHH & ERIDGIK: & SEF $\& 4$ & 10.312 \\
\hline ENI: IN I TASWEST & ERTIOHES & NDUE.5 & 10707 \\
\hline KELSEYSE & EROOIKS & SEFG 4 & 10312 \\
\hline SIODTT AHIIFFEFES & E:FIOIK: & FEE 64 & 10287 \\
\hline VIEOFAS: & ERIIIIS: & FEEBS7 & 11545 \\
\hline VIEOIRASSE & EFIIIIKS: & 0I:T6: & 12105 \\
\hline
\end{tabular}


THE BOINTIES FEQUIESTEI AFE - LIVEOAK.

THE MINIMIIM, MAXIMUIM [IEF'TH FEGIIIESTELI IS ALL

THE LOWEF: LIMIT IIN YEAF IS $19 \mathrm{ALL}$

\begin{tabular}{|c|c|c|c|}
\hline FIELI NAME & COUINTY & LIATE & [IEF'TH \\
\hline EFIASLAIJEBOO & LIVEDAK: & MAF:SB & 8817 \\
\hline C:HAF'A & LIVEDAK: & .JAN44 & $\theta 16 \theta$ \\
\hline CHAFASL I CKSEDOS & LIVEOAK: & Alllis:4 & 8228 \\
\hline EHAF'AWILLOXX $1 \mathrm{ST}$ & LIVEGAK: & IAN52 & 3637 \\
\hline EHAFAWILCOX $15 S$ & LIVEDAK: & MAFIEE & 816.5 \\
\hline DHAFABG50 & LIVEDAK: & SEF'S1 & 96.59 \\
\hline CLAYWESTWLDWEF & LIVEGAY: & SEF'46 & $101 \geq 1$ \\
\hline CLAYWESTWLNOFT & LIVEOAK & 61:-T5: & 9446 \\
\hline CLAYWESTWM I CICIL & LIVEOAK: & .11ال.5z & $100 \leqslant 4$ \\
\hline r:LAYWESTWIIFF'ER & LIVEDAK & -IAN47 & 9390 \\
\hline CLAYWESTW $: 30$ & LIVEIAA: & [II:TES & 9342 \\
\hline OLAYWEST $8 \% 00$ & LIVEGAK: & MAF:S: & 8900 \\
\hline [INEFIIWESTW1SE & LIVEOAK & AlIIS6Z & 13606 \\
\hline [UUNNLIIL INIEW IL & LIVEGAK: & NDVS7 & $9: 374$ \\
\hline IIINNSL I CKEE & LIVEOAR: & -IANGS: & 8202 \\
\hline DILINNSL I CKWILE & LIVEGAK & MAYSS & 8076 \\
\hline GEORILEWEST & LIVEDAY & & 10170 \\
\hline GEERFIEWESTESSO & LIVEOAK: & NOUVS9 & 8521 \\
\hline HARFI I SW I LEIIX & LIVEOAY: & DEE: 64 & 9164 \\
\hline HARR I SWILCOXX & LIVEOAAK & & 8616 \\
\hline HARF I SNEMACK & LIVEOAAK & MAY $E 7$ & 8152 \\
\hline HAFF I SNEMASS: & LIVEOAK: & AF'F:S9 & 5488 \\
\hline HAFIF I SNESEGAA & LIVEGAK & JANEZ & 8366 \\
\hline HAFF I SNESEGI: & LIVEOAKK & FEE:S: & $5 \leqslant 12$ \\
\hline HAFF I SSE 8060 & LIVEOAK: & FEB 69 & 8066 \\
\hline HCIIIIMANW ILEOXX & LIVERIAK: & SEF'S 1 & $9: 22$ \\
\hline ISAALKSELIWARLIS & LIVEQAAK & AlJIS57 & 12456 \\
\hline KARCINSOUITHIST & LIVEOAK: & JAN4: & 8180 \\
\hline KAFIONSOILITHZNDI & LIVEOAAK. & MAY $B O$ & 5152 \\
\hline KATZSLICKWILE: & LIVEOAKK & MAY5F & 10531 \\
\hline KITTIEWEST IZ4 & LIVEOAK: & FEESB & 8237 \\
\hline KITTIEEIIFINS & LIVEDAK: & & 10170 \\
\hline KITTIEEIIFINSWIJP & LIVEOAAK & FEE:B: & 7066 \\
\hline KITTIEELIRNSWF1 & LIVEDAAK & SEFB: & 9122 \\
\hline KITTIEEIJFNS $\% 40$ & LIVEGAKK & MARBS & 9404 \\
\hline KITTIEEIJINE 109 & LIVEDAKK & FEETO & 10817 \\
\hline LEDWIGZNDTOMLY & LIVEOIAK & 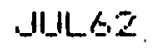 & $\$ 524$ \\
\hline LYNEMAX INEMILL & LIVECIAK & [IEL: & 8865 \\
\hline MAXINE & LIVEDAK: & NIIV4S: & 8820 \\
\hline MIKESKAWILEOXX & L. IVEDAK: & MAY5\% & 10058 \\
\hline MIKESKSANLIILING & LIVEDIAK: & .JNGE & 9090 \\
\hline DAKVILLESWLEXM & LIVEDAK & AF'FIS9 & 8488 \\
\hline SALTR:FEEK I $Z 4$ & LIVEOAAK: & [IER:68 & $82: 37$ \\
\hline S:L:HIILZZ & LIVEOAY: & & 9500 \\
\hline SILLWESTMARKHAN & LIVECIAK & MAYB 1 & 9100 \\
\hline
\end{tabular}




\begin{tabular}{|c|c|c|c|}
\hline 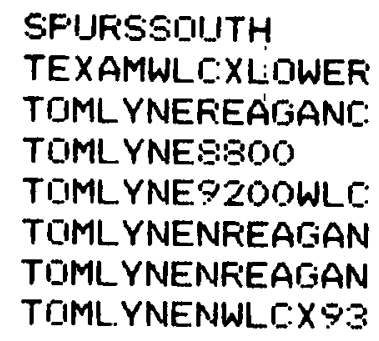 & $\begin{array}{l}\text { LIVEOAK } \\
\text { LIVEOAK } \\
\text { LIVEOAK } \\
\text { LIVEOAK } \\
\text { LIVEOAK } \\
\text { LIVEOAK } \\
\text { LIVEGAK } \\
\text { LIVEOAK }\end{array}$ & $\begin{array}{l}\text { JUN49 } \\
\text { MAYS3 } \\
\text { OCT64 } \\
\text { NOVS5 } \\
\text { SEF48 } \\
\text { OCTO6 } \\
\text { FEBS6 } \\
\text { JAN71 }\end{array}$ & $\begin{array}{r}8314 \\
9602 \\
10440 \\
8758 \\
9230 \\
9843 \\
9980 \\
9397\end{array}$ \\
\hline
\end{tabular}




\section{APPENDIX B}

Core Record of Shell No. 13 McAllen

McAllen Ranch Field

Hidalgo County, Texas

(Courtesy of Shell Oil Company) 
APPENDIX

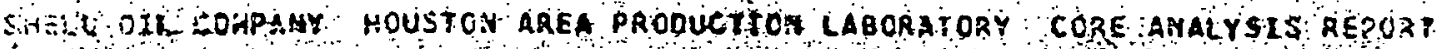

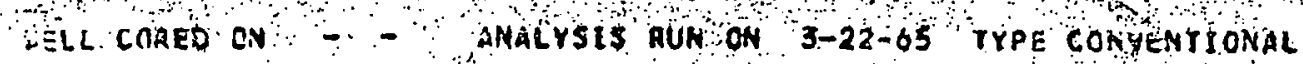

COCAYION CODE 2422200667406399000130090 PERMISN QASIN HO

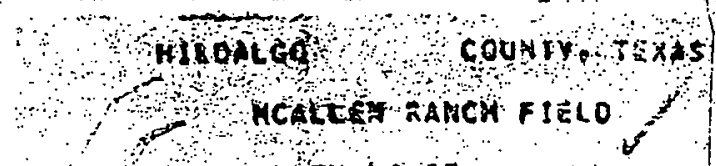

SHELL HAOA.MCALGEN HO.T3

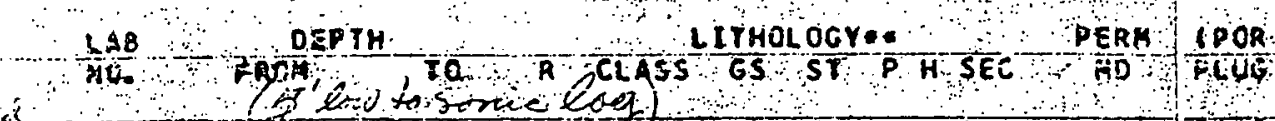

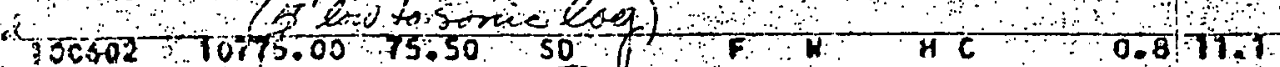

$100603 \quad 10776.0070 .50 \cdot(S H) \quad H C S F-0.026 .1$

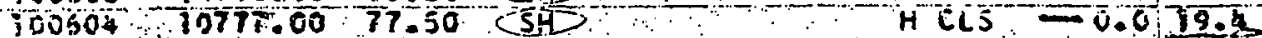

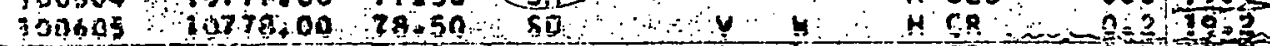

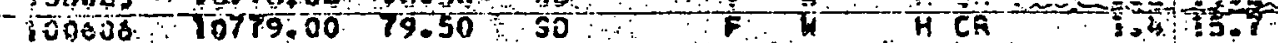

$1000070780.00 \quad 80.50 \quad 50 \quad F \quad H C R \quad 30$

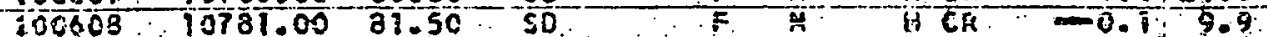

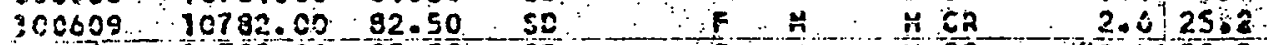

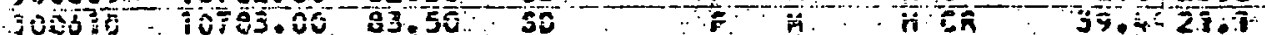

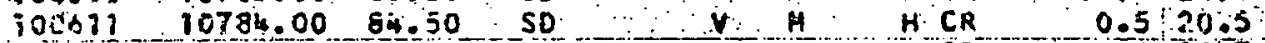

10501210725.50 86.00 SO H H CR 0.0079 .7

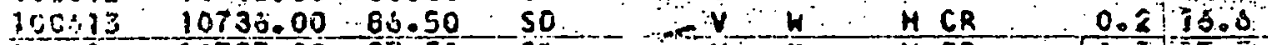

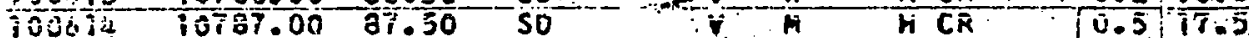

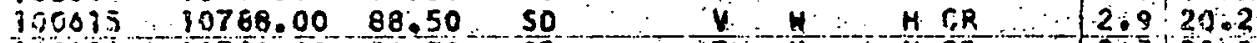

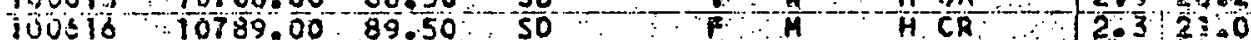

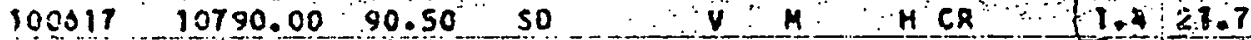

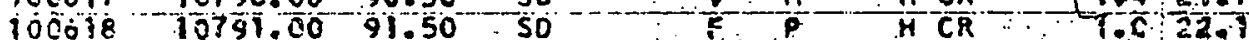

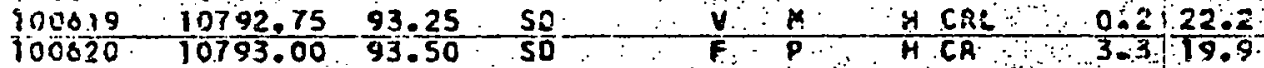

$100321 \quad 10794.0094 .50$ 50 F 0 CR 25.6e 21.3

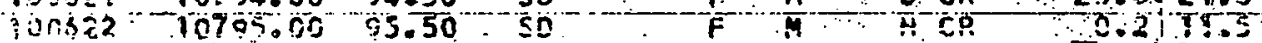

$100123 \cdot 10795.7596 .25$ SD F F H CR [0.7 23.7

10002410797.0097 .50 SO F H.CR

10062510798.0099 .50 SD $\quad$ F H CR $=0.130 .0$

$100026-10799.0099 .50 \% 50-0$ CR

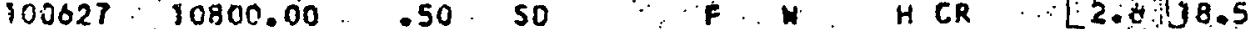

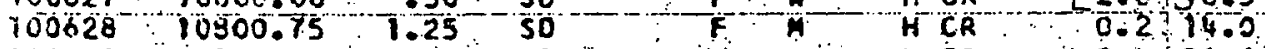

$100029 \quad 10302.002 .50$ SD $\quad$ S H CR $\quad$ H. $0.4+21.5$

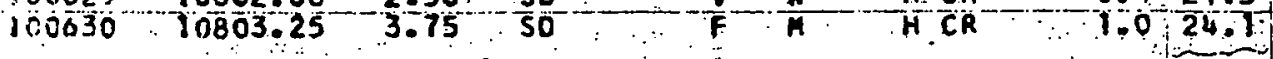

* ROCX TYPE

1.ITHOLCÖZC AN ANHYDRITE OACHTE VERY HELL A NOT VISIBEE

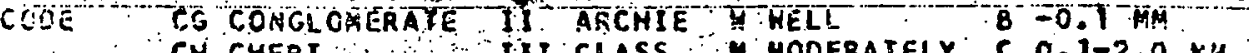

CH CHERT

LS LIHESTONE L COARSE SE-SPECIAL SYHECLS

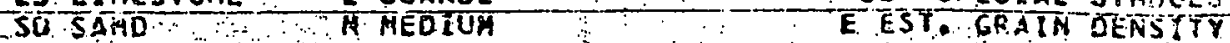

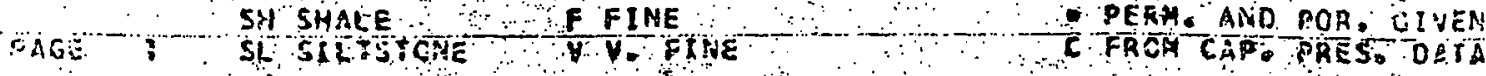


SHELL OIL COAPANY HOUSTON AREA DROOUCTIOK LABORATORY CORE ANALYSIS REPORT

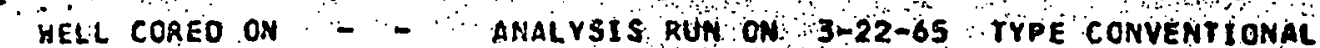

LCCATION CODE 2422200087406398000130090 PERMIAN BASIN NO

H1LOALOQ OOU COUTY TEXAS

\section{$\therefore$ MCALIEN AANCH FIETO}

SMELL A.A.MCALLEN NO.13

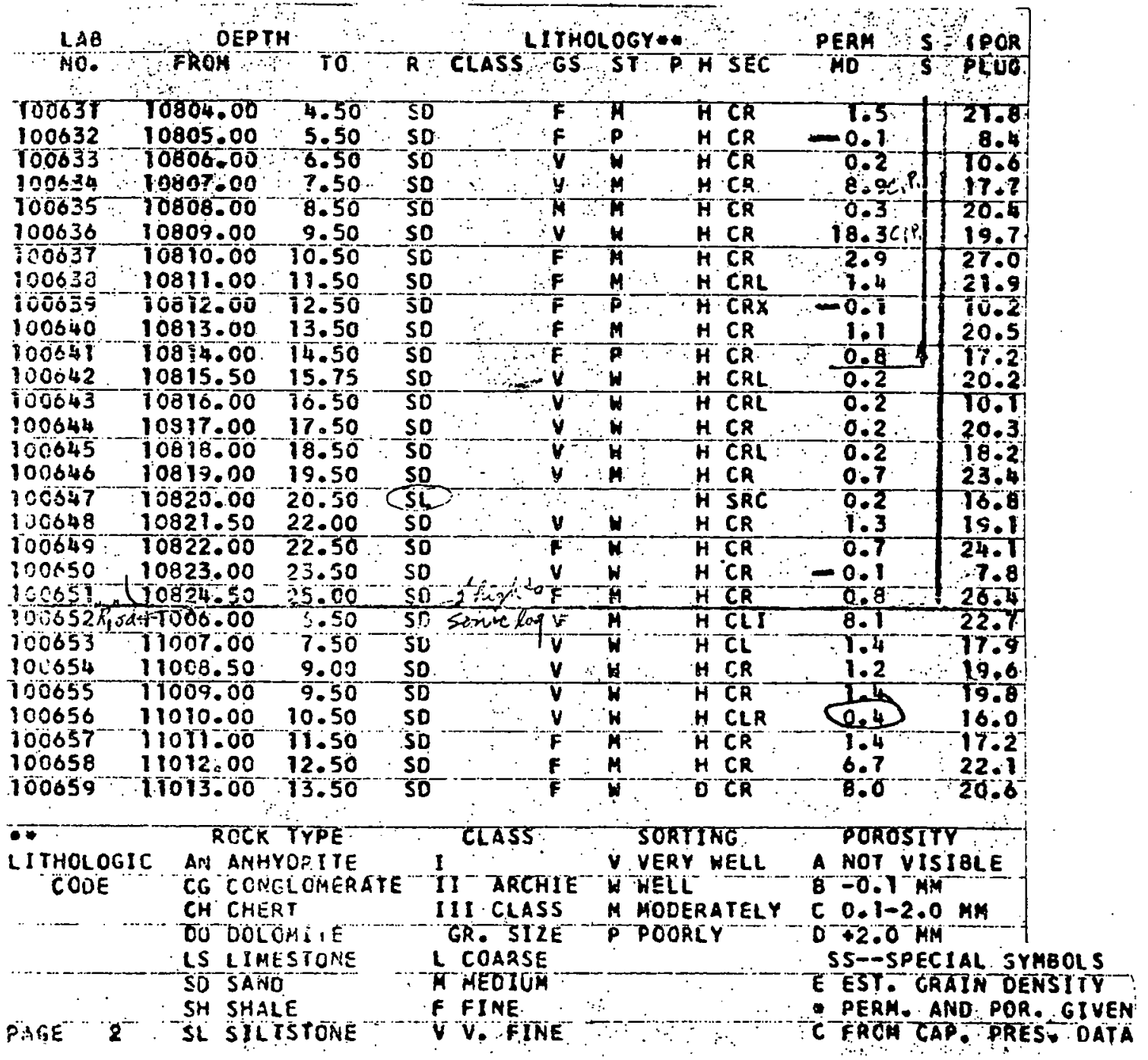


5HELL OIL COMPANY HOUSTON AREA PROOUCTION LABORATORY CORE AKAEYSTS REPORT WELL CORED ON - - ANALYSIS RUN ON $3-22-65$ TYPE CONVENTIOHAE LOCATION CODE 2422200067406398000130090 PERMIAN BASIN NO

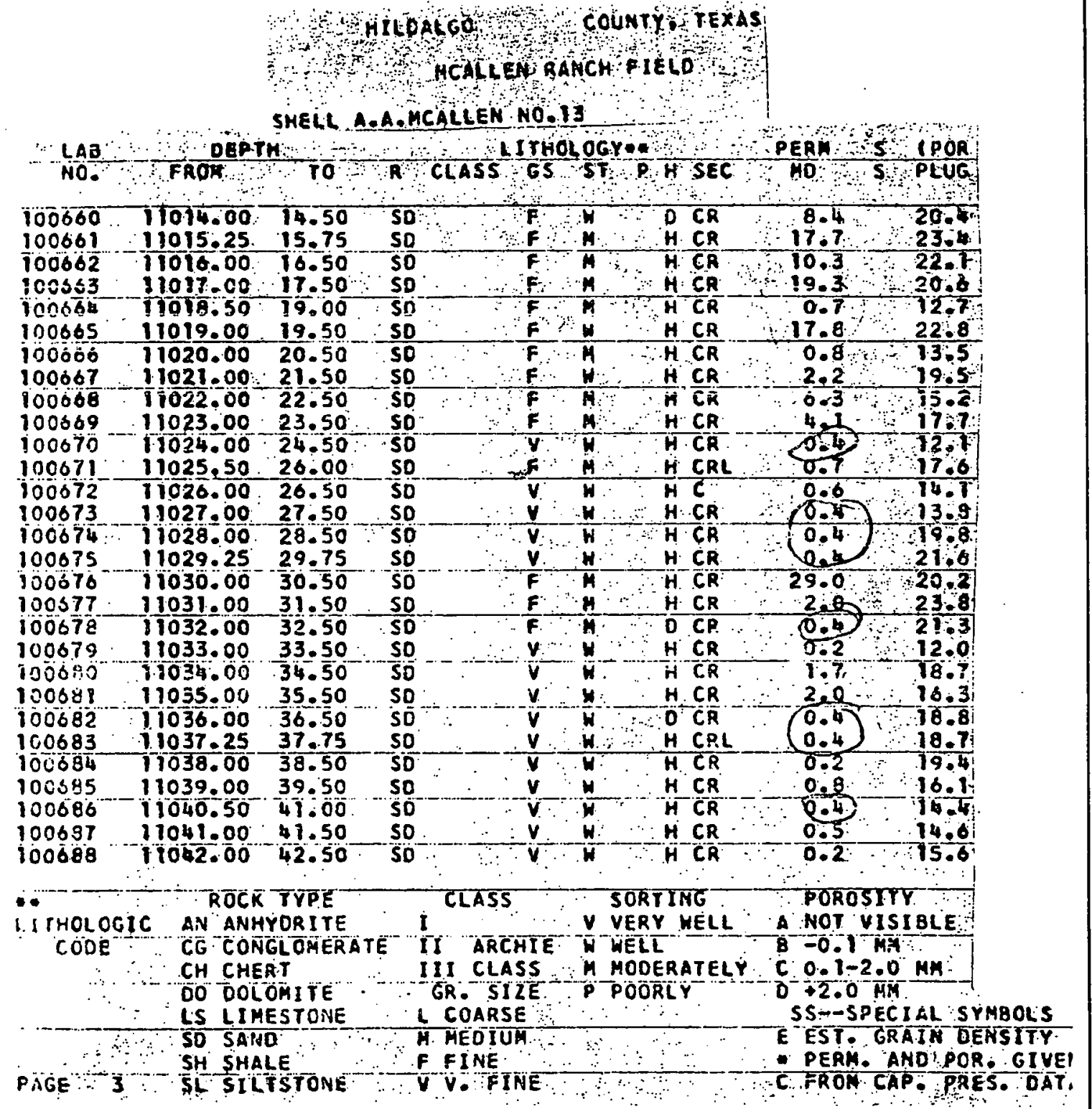


STELL OLL COMAANY HOUSTON AREA PRODUETION LABORATORK COAE ANALYSTS REPORT HeLC CGREO ON - - ANALYSTS RUNON OB-22-65 TYPE CCNVENTIONAL

LOCATION CODE 2422200007406398000130090 PERMIAN BASIN NO

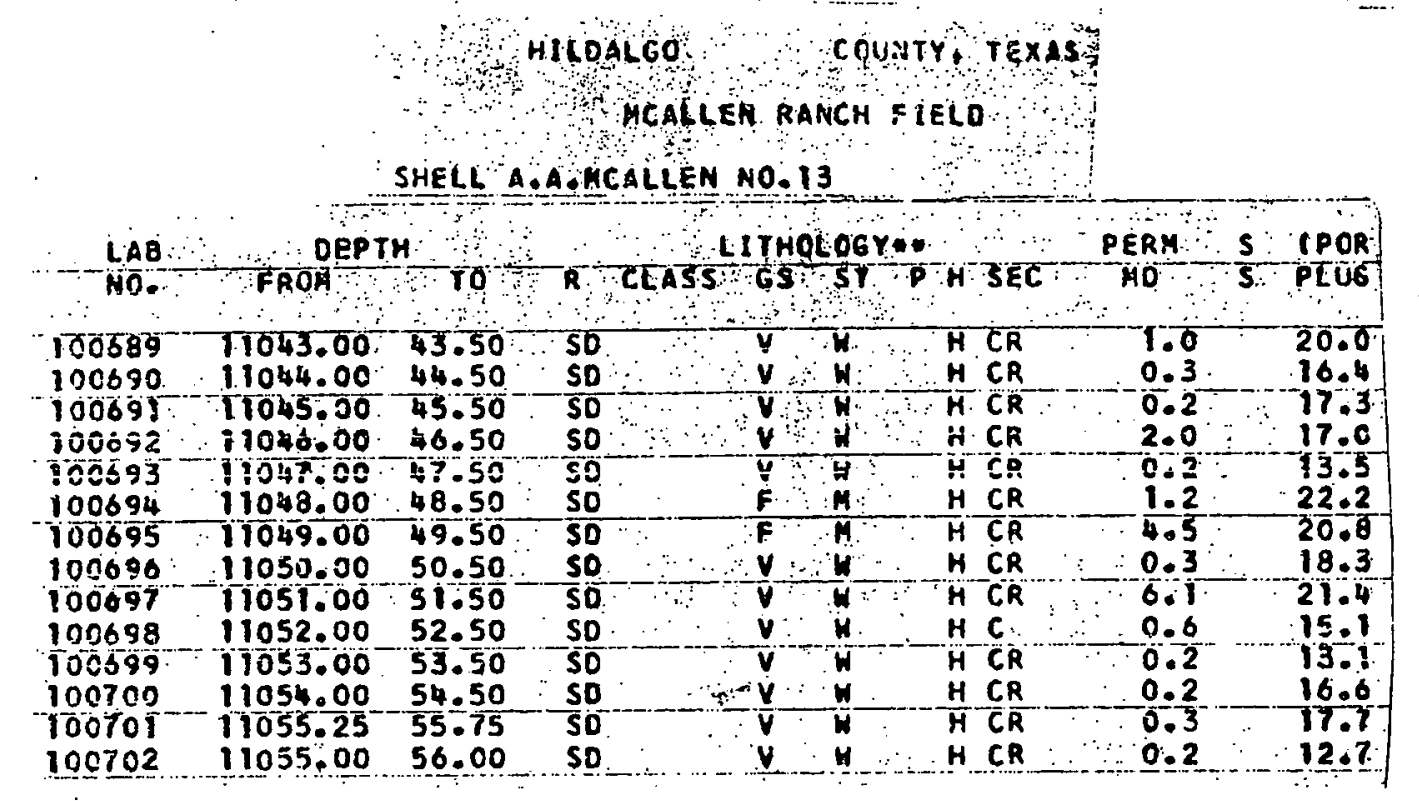

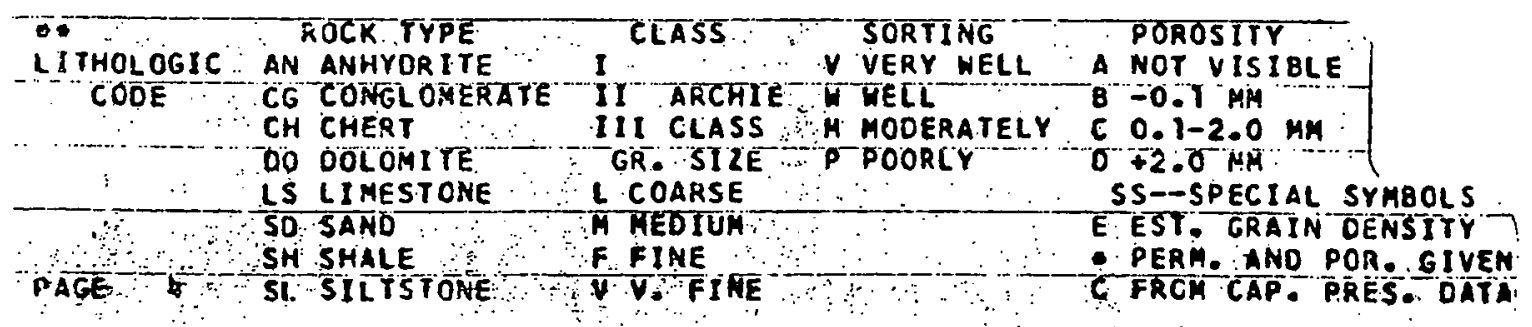


SHELL OIL COMPAMY HOUSTON AREA PROPUCTIOK LAOORATORY CORE AXALYS IS REPORT WEL COREO ON - ANALYSTS RUA ON 3-24-65 TYPE CONUENT ONAL

LOCATION CODE 24222000OT406398000130125 PERHIAN BASIN NO

$$
\begin{aligned}
& \text { H HILOALO OP COUHTY TEXAS } \\
& \text { - } 2 \text { HCALEEA RANCH F IELO }
\end{aligned}
$$

SHELL AOA OHCALLEN NO.13

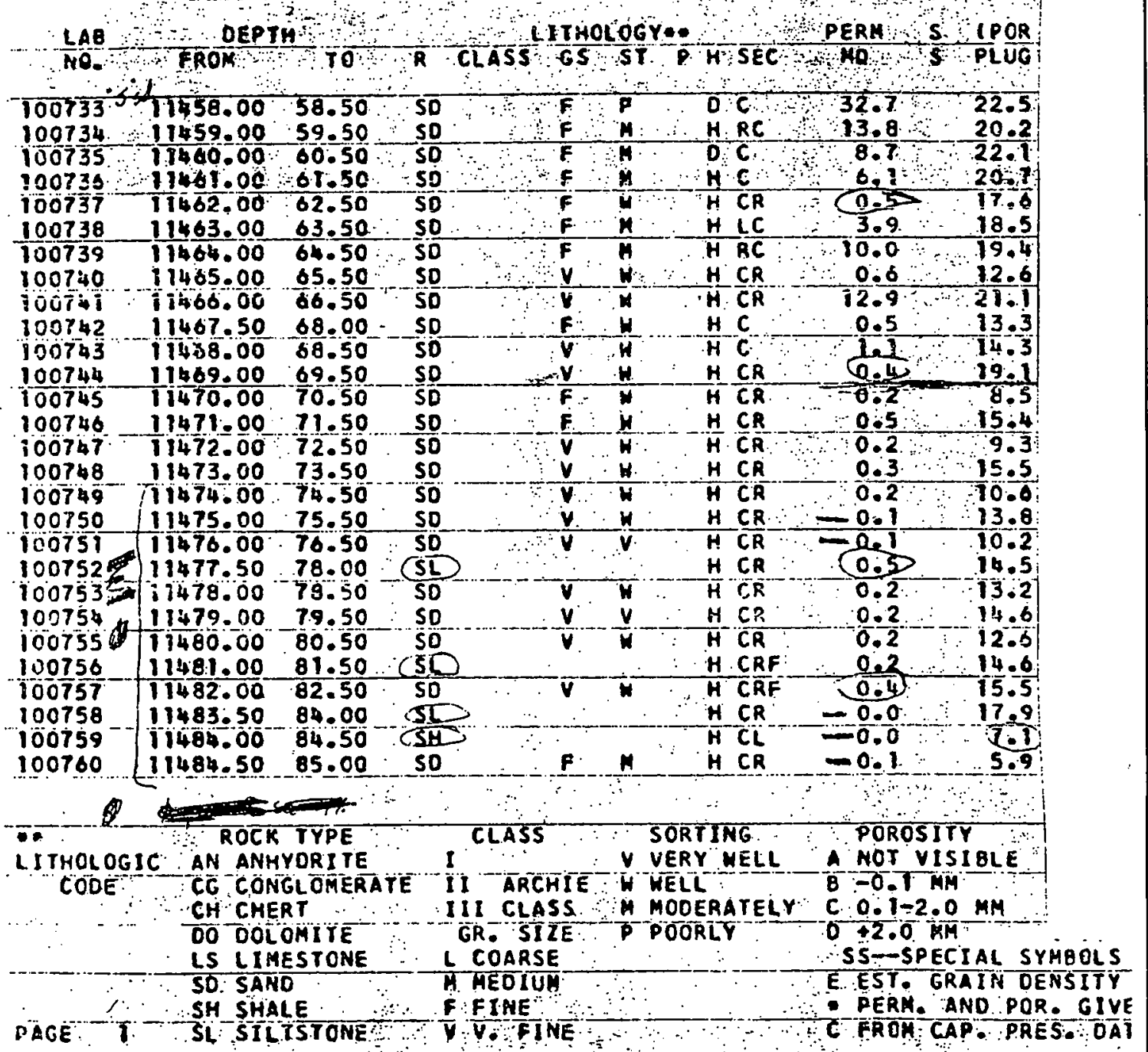


SHELL OLL COHPANY HOUSTON AREA PRODUSTION LAQOAATORY CORE ANALYSIS REPORT HEL CORE OM LOCATION CODE 2422200067406398000130150 PERHIAN BASIN NO

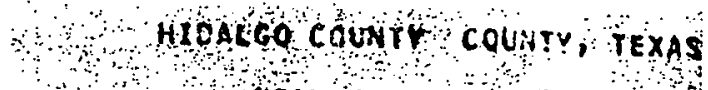
WCALLEN RANCH FIELO

SHELL A.A. MCALLEN NO.13

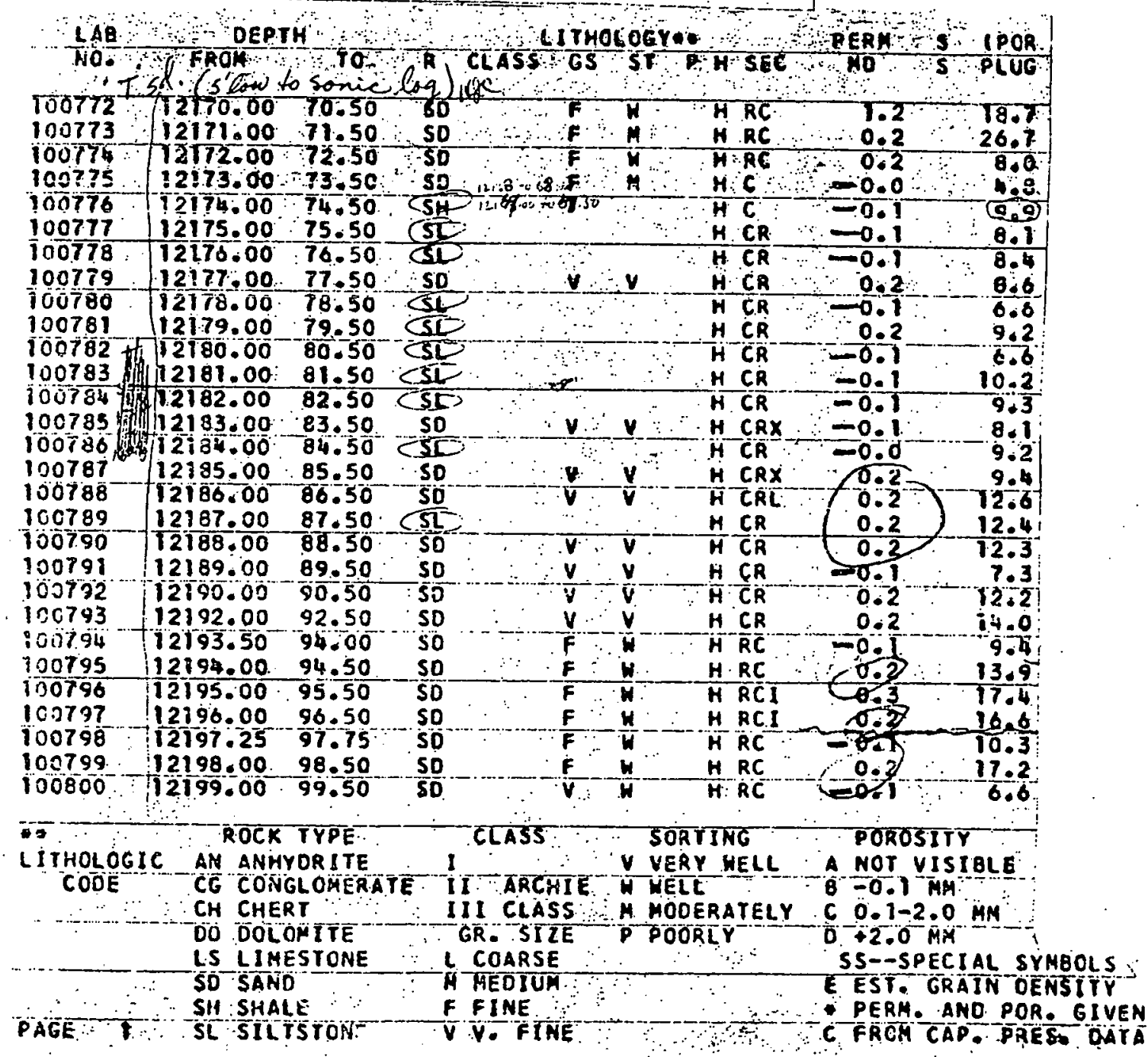


SHEL OIL COMPANY HOUSTON AREA PROQUSTION LABORATORY GORE ANALYSIS REPORT C. HELL CORED ON - ANALYSIS RUN ON $3-30-65$ TYPE CONVEATIOKAL
LOCATION CODE 2422200007406398000130150 PERMIAN BASIN NO

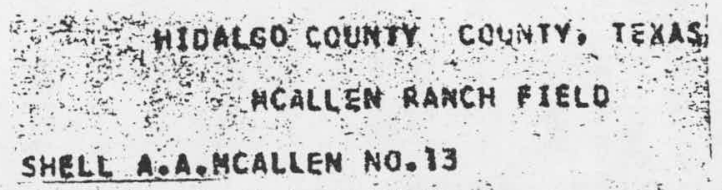

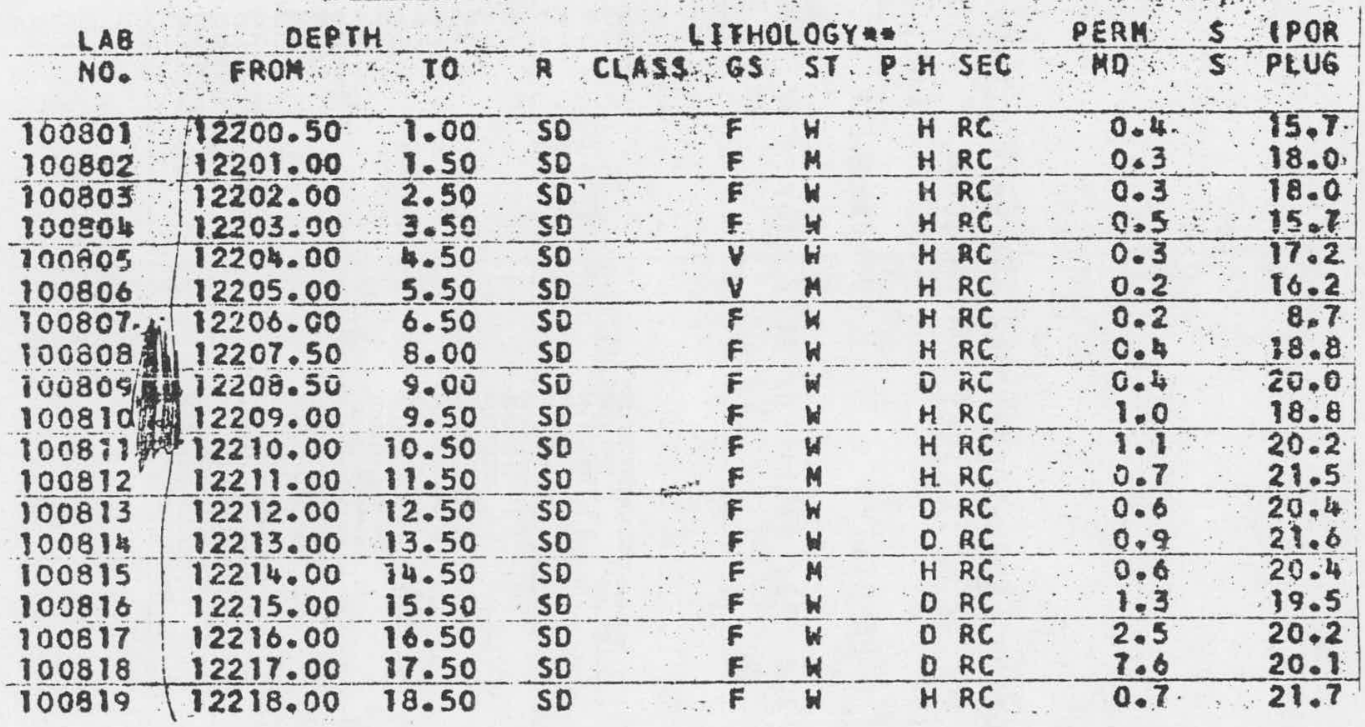

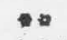

L.ITHOLOGIC CODE

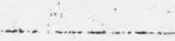$$
\ldots+\ldots+\ldots
$$

SH SHALE

PAGE 2 SL SILTSTONE
ROCK TYPE

AN ANHYORITE CG: CONGL

CH. CHERT

OO DOLOMITE

S LIMESTONE

ATE

CLASS 1

II $\mathrm{CLASS}$ GR. SIZE L COARSE M MEDIUH F FINE V. FINE
SORTING POROSITY A NOT VISIBLE $8-0.1 \mathrm{MM}$ M MODERATELY C $0.1-2.0 \mathrm{MH}$ P POORLY D $42.0 \mathrm{MH}$ SS - SPECIAL SYNBOLS E EST. GRAIN DENSITY - PERh AND POR . GIVEN C FROA CAP PRES. OATA 


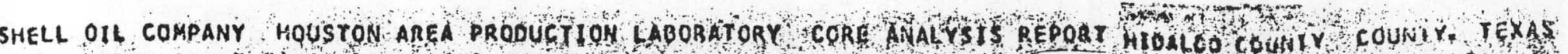

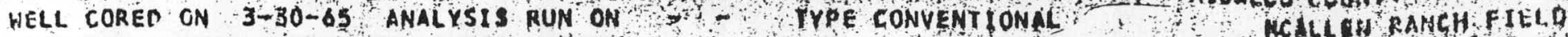

LOCATION TODE 2422200067406398000130150

GRAIN DENSITY
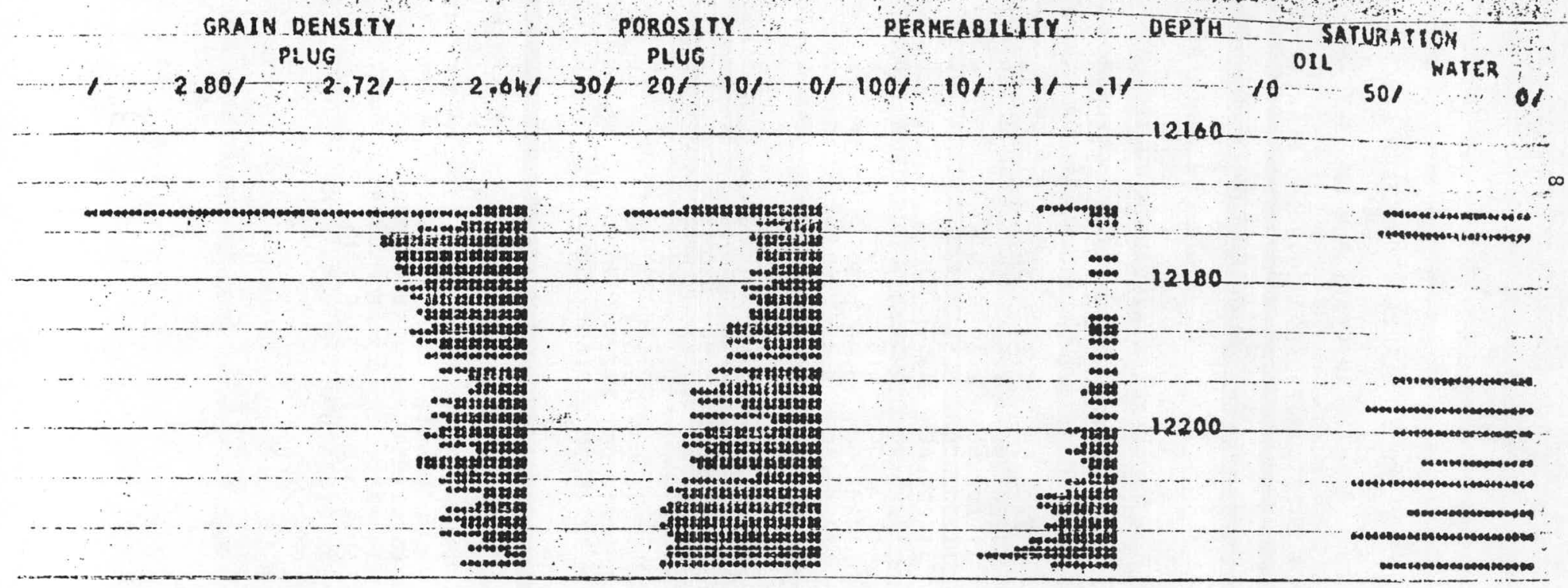
SHELL OLL COMPANY HOUSTON AREA PRODUCTION LABORATORY CORE ANALYSIS REPORT HELL COBED ON 3-24-65 ANALYSIS RUN ON- - -T TUPE CONVENTIONAL LOCATION COOE 2422200067406398000130125

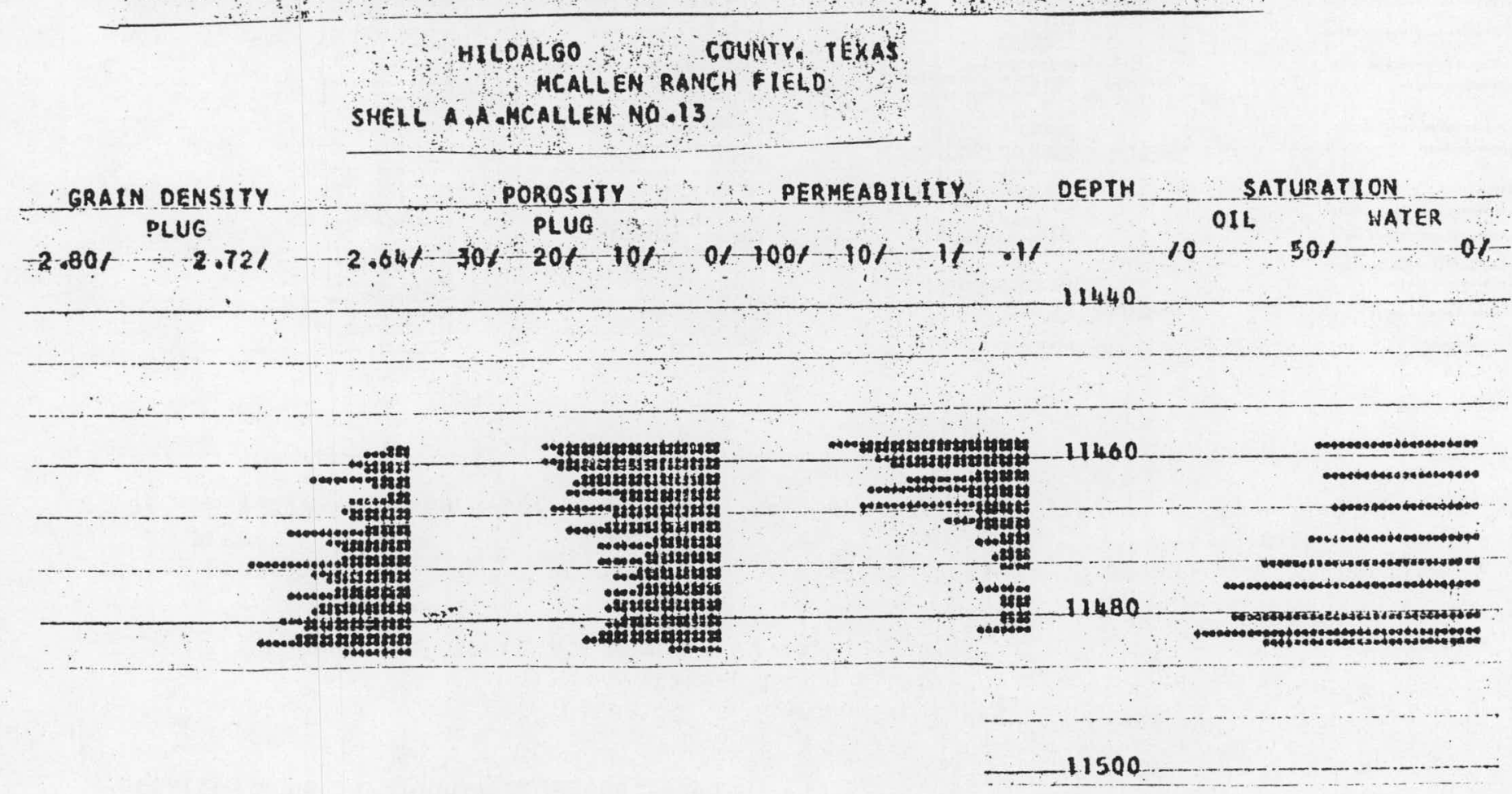


SHELL OIL COHPANY HOUSTON LREA PROQUCYION LAOORATORY COBE ANALYSIS REPORT WCLL COREO ON 3-22-35 ANALYSIS RUN ON - - TVPE CONVENTIONAL

LOCATION CODE 2422200087406398000130090

$$
\begin{aligned}
& \text { HLOOALO COUNTY TEXNS } \\
& \text { HCALLEN RANCH FIEID }
\end{aligned}
$$

SHELL A A.MCALLEN NO.13

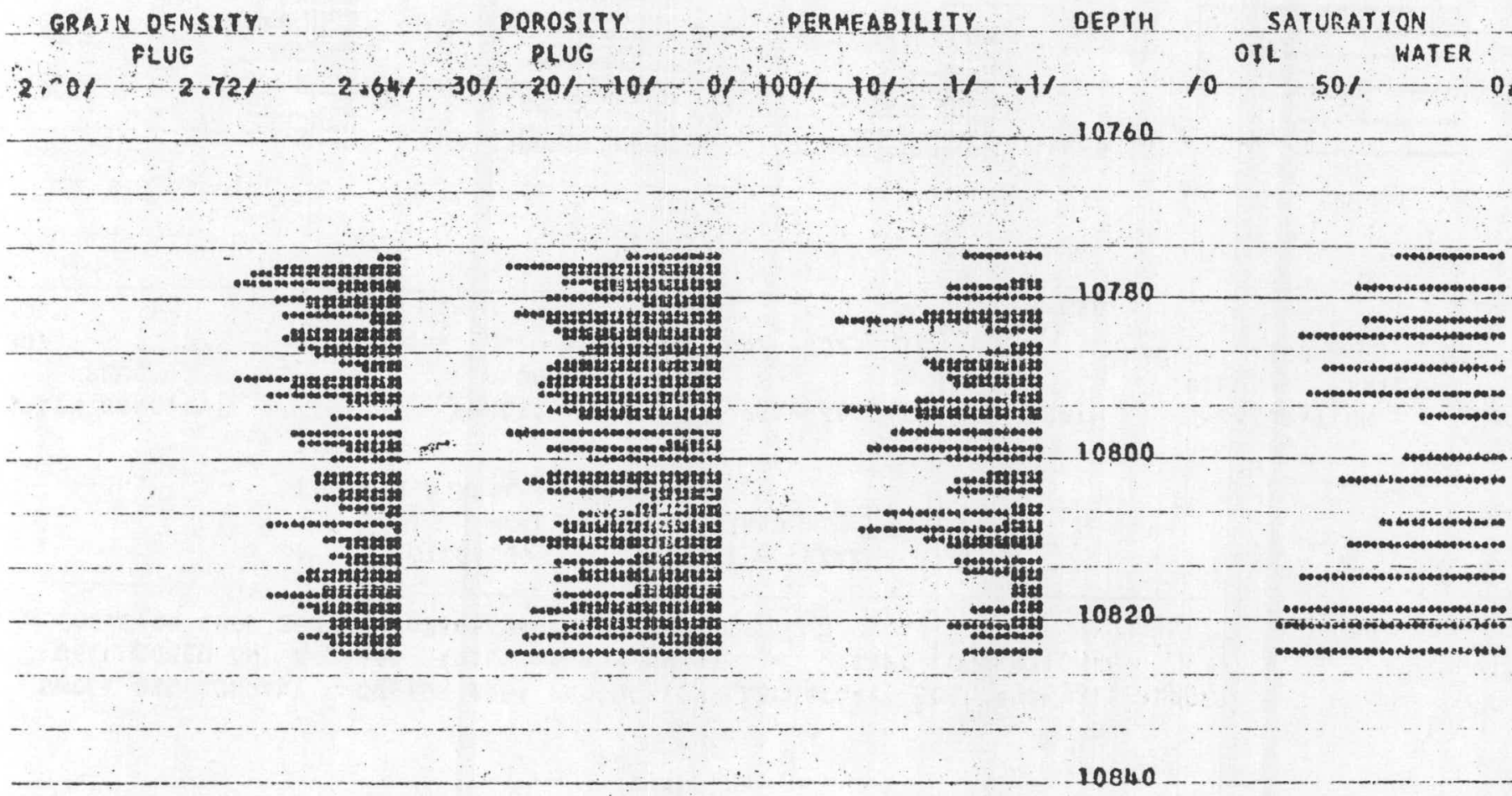




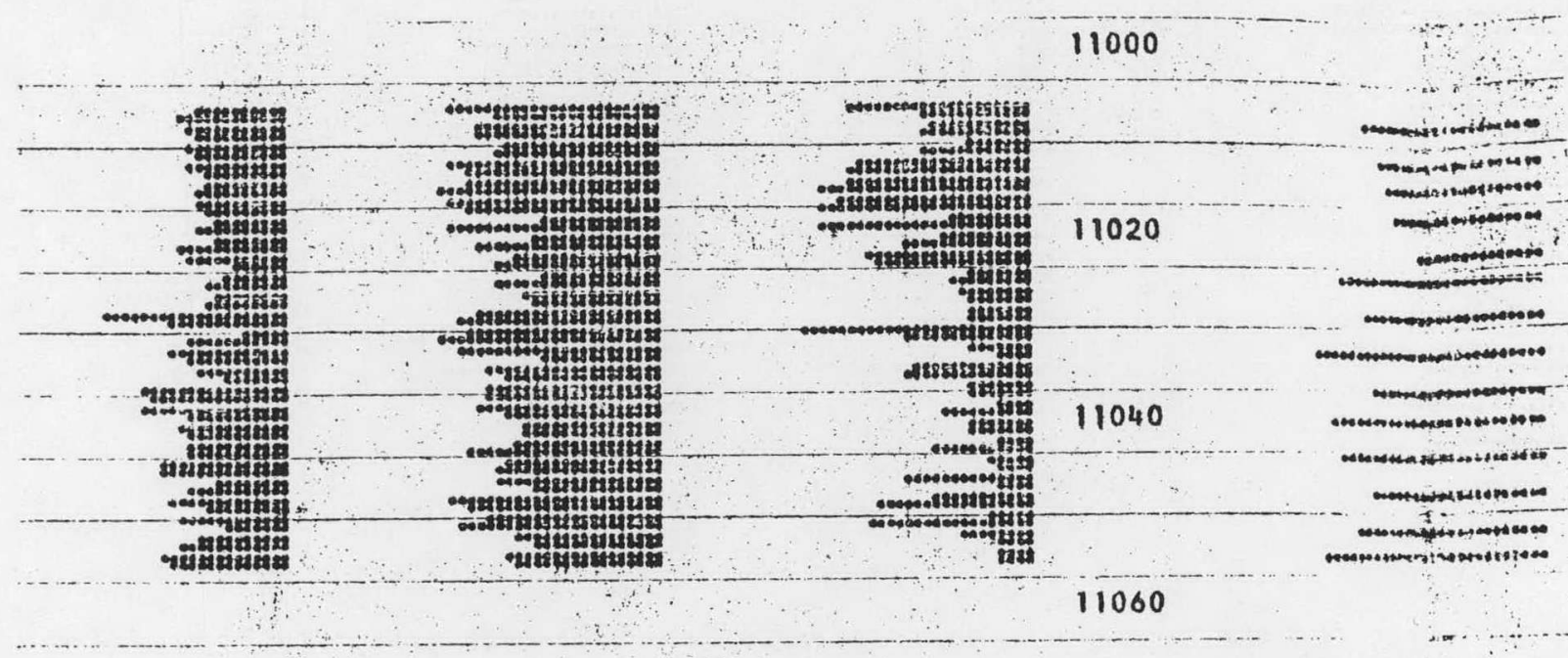


SHELL OIL COMPANY HOUSTON AREA PRODUCTION LABORATORY CORE ANALYSIS REPORT HELL CORED ON 3-22-65 ANALYSIS RUN ON - - TYPE CONVENTIONAL

LOCATION CODE 2422200067406398000130090

HILDALGO COUNTY. TEXAS

MCALLEN RANCH FIELD

SHELL A.A.MCALLEN NO.13

GRAIV DENSITY
PLUG
$2.41 /$

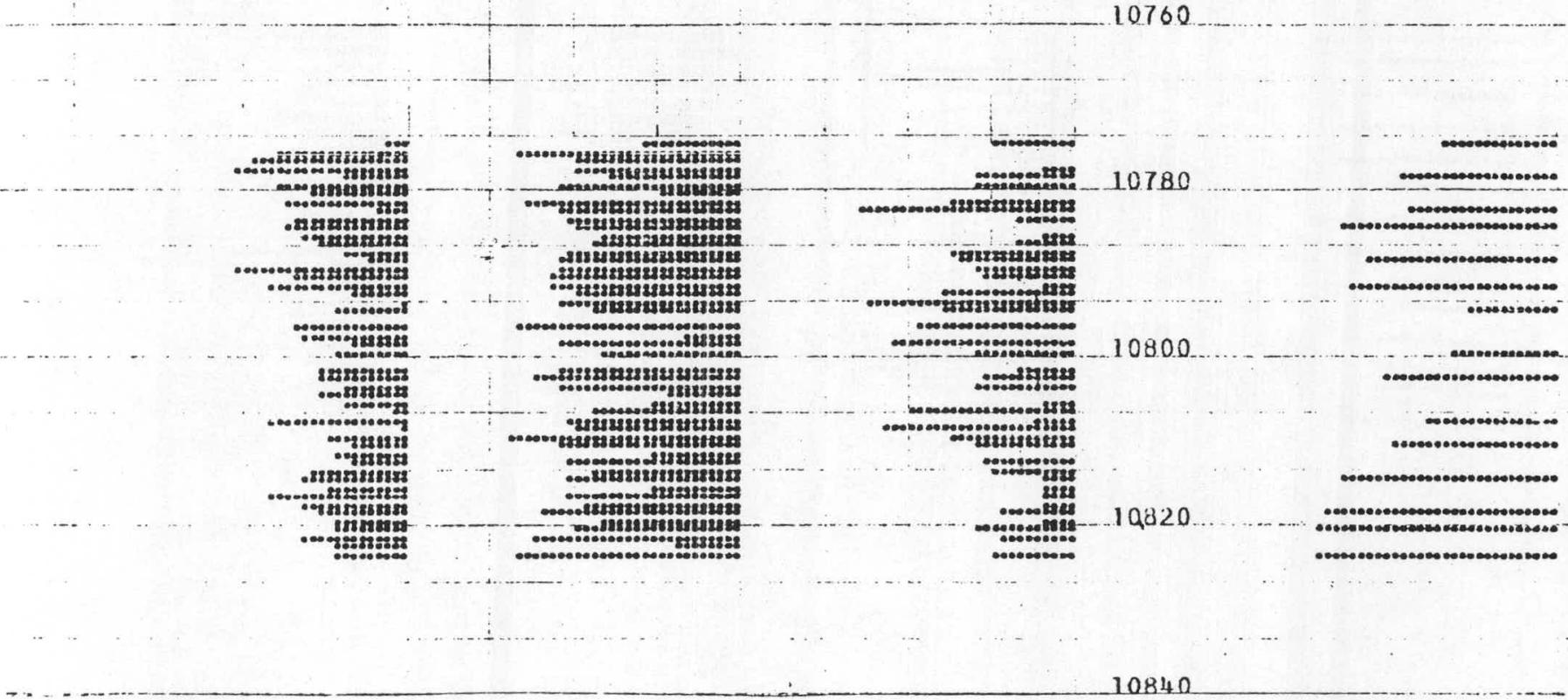




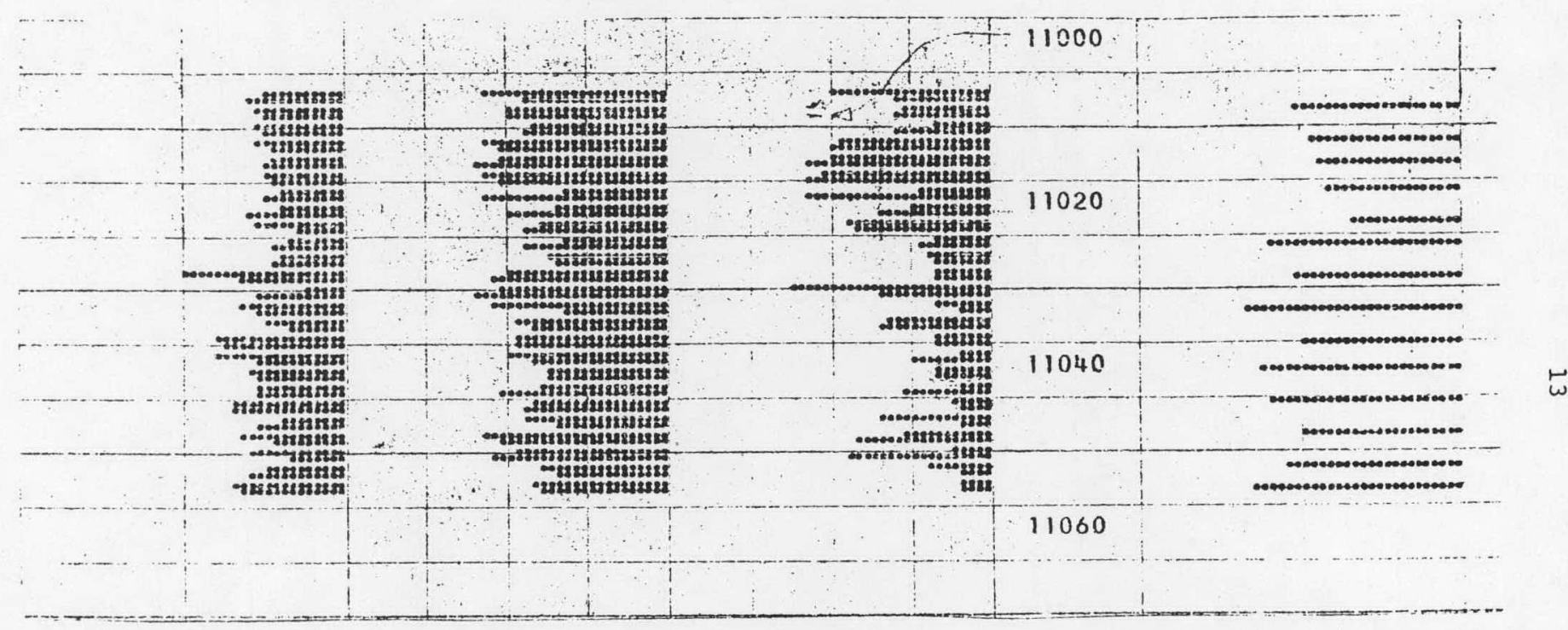


APPENDIX C

Calculation of Pressure and Flow From a Single Well in the Center of a Circular Reservoir 


\section{APPENDIX C-CALCULATION OF PRESSURE AND FLOW FROM A SINGLE WELL IN THE CENTER OF A CIRCULAR RESERVOIR}

1. Flow During Transient Conditions. For time less than the readjustment time, which is the time for the pressure disturbance to reach the edge of the reservoir,

$$
T_{r}=\frac{0.04 \mu C_{e} r_{e}{ }^{2}}{k}
$$

where

$T_{r} \quad$ - The readjustment time

$\mu \quad-$ Viscosity of the fluid in centipoise $(0.2$ in example in text)

$C_{e} \quad$-Compressibility of the reservoir $\left(6.23 \times 10^{-5}\right.$ in example)

$r_{e} \quad$-Radius of the reservoir $(9,326 \mathrm{ft}$ in example)

$k \quad-$ Permeability (100 md in example)

The calculation of $T_{r}$ for example in the text,

$$
\begin{aligned}
T_{r} & =\frac{04(0.2)\left(6.23 \times 10^{-5}\right)(9326)^{2}}{0.1} \\
& =433.5 \text { days, or } 1.2 \mathrm{yr} .
\end{aligned}
$$

2. An Equation for the Flow of Fluids from a Reservoir During the Transient Period.

$$
Q=\frac{14.16 k h}{\mu \ln \frac{14.22 k t}{\emptyset \mu C_{e} r_{w}^{2}}}\left[P_{r}-P_{s}-P_{h}-P_{f}\right]
$$

where

$Q \quad-$ Flow in bbl/day

$k \quad$-Permeability in md

$h \quad-$ Thickness in feet

$t \quad$-Time in days

$\emptyset$-Porosity, fraction

$\mu \quad-$ Viscosity centipoise

$C_{e} \quad$-Compressibility

$r_{w}$-Radius of the well in $\mathrm{ft}$

$P_{r} \quad$-Initial pressure in reservoir

$P_{s} \quad$ - Pressure at the surface

$P_{h} \quad$ - Pressure due to the hydrostatic head

$P_{f} \quad$-Friction loss due to flow up the pipe (for 9-5/8-in.-diameter pipe 12,000-ft long flowing at rate of $100,000 \mathrm{bbl} /$ day, pressure drop is $280 \mathrm{psi}$ ) 
Sample calculation after one day of open flow (parameters from example in text)

$$
Q=\frac{14.16(0.1)(500)}{0.2 \ln \frac{(14.22)(0.1)(1)}{(0.2)\left(6.23 \times 10^{-5}\right)(0.401)^{2}}}=[(10,000)-(0)-(5200)-(280)]
$$

$Q=1,026,000 \mathrm{bbl} / \mathrm{day}$

3. For Times Greater Than $2 \mathrm{Tr}_{2}$ the Semisteady-State Flow Equation is

$$
P_{s}=\left(P_{r}-P_{h}-P_{f}\right)-\left(\frac{5.615 Q t}{\pi r_{e}{ }^{2} h \emptyset C_{e}}\right)-\left(\frac{Q \cdot \mu}{7.08 k h}\right)\left\{\left[\ln \left(\frac{r_{e}}{r_{w}}\right)\right]-\frac{3}{4}\right\}
$$

A sample calculation at 867 days (beginning of semisteady-state flow) for the example in the text

$$
\begin{aligned}
P_{s}= & (10000-5200-280)-\frac{5.615 \times 10^{5}(867)}{\pi(9326)^{2}(500)(0.12)\left(6.23 \times 10^{-5}\right)} \\
& -\frac{\left(10^{5}\right)(0.2)}{\pi(9326)^{2}(500)(0.12)\left(6.23 \times 10^{-5}\right)}\left\{\left(\ln \frac{9326}{0.401}\right)-\frac{3}{4}\right\}
\end{aligned}
$$

$P_{s}=3517 \mathrm{psi}$

\section{Pressure at the Surface During Transient Period}

$$
P_{s}=\left(P_{r}-P_{h}-P_{f}\right)-\left[\frac{Q / \mu}{14.16 k h \ln \left(\frac{14.22 k t}{\mu C_{e} \emptyset r_{w}{ }^{2}}\right)}\right]
$$

The initial pressure at the surface at $t=0$ in the example,

$$
P_{s}=10,000-5,200-280=4,520 \mathrm{lb}
$$

Pressure at the surface after one day with $Q=100,000 \mathrm{bbl}$ water/day in the example,

$$
P_{s}=\frac{4,520-\left(10^{5}\right)(0.2)}{14.16(0.1)(500)}\left[\ln \left(\frac{(14.22)(0.1)(1)}{(0.2)\left(6.23 \times 10^{-5}\right)(0.12)(0.401)^{2}}\right)\right]=4,080 \mathrm{lb}
$$

